NBER WORKING PAPER SERIES

\title{
THE SEXUAL ACTIVITY AND BIRTH CONTROL USE OF AMERICAN TEENAGERS
}

\author{
Phillip B. Levine
}

Working Paper 7601

http://www.nber.org/papers/w7601

\section{NATIONAL BUREAU OF ECONOMIC RESEARCH}

1050 Massachusetts Avenue

Cambridge, MA 02138

March 2000

This paper was prepared for the NBER conference, "An Economic Analysis of Risky Behavior Among Youths." I would like to thank Marcellus Andrews, Jon Gruber, Ann Velenchik, and participants at the June preconference and December conference for their helpful suggestions and to Joyce Abma, Gil Crouse, Bob Schoeni, Sharon Terman, and Tori Velkoff for their assistance in acquiring and using the data. The views expressed herein are those of the author and not necessarily those of the National Bureau of Economic Research.

(C) 2000 by Phillip B. Levine. All rights reserved. Short sections of text, not to exceed two paragraphs, may be quoted without explicit permission provided that full credit, including $(\mathbb{C}$ notice, is given to the source. 
The Sexual Activity and Birth Control Use of American Teenagers

Phillip B. Levine

NBER Working Paper No. 7601

March 2000

JEL No. J1

\section{ABSTRACT}

This paper evaluates the evidence regarding teens' sexual activity and birth control use with an emphasis on the contribution of economic analysis. For non-economists, teen sexual activity is often considered spontaneous and irrational, and pregnancies are viewed as "mistakes." Alternatively an economic framework, which focuses on the costs and benefits of alternative actions and utilizes more sophisticated statistical methods, can be applied to these "decisions" as well. After documenting recent trends, I review prior economic and non-economic research regarding the determinants of these activities. Economic models differ in that they predict unprotected sexual activity will decline if its costs, broadly-defined, increase. After presenting evidence documenting who engages in sexual activity and uses birth control, I report an analysis of state-level data over time that examines whether changes in costs are related to changes in these behaviors. The results support the notion that costs matter. The final section reviews the evidence regarding the impact of teen child-bearing on women's subsequent well-being to examine the magnitude of its cost.

Phillip B. Levine

Department of Economics

Wellesley College

Wellesley, MA 02468

and NBER

plevine@wellesley.edu 


\section{INTRODUCTION}

Pregnancies among America's teenagers have caught the nation's attention as one of our greatest troubles. A Gallup poll conducted on May 23 and 24 of 1999 found that 7 percent of those surveyed reported that youth/teen pregnancy was "the most important problem facing this country today" (Gallup Organization, 1999). It was the fifth most common specific problem reported. The concern about teen pregnancy has even led to national goals regarding its reduction. The first family planning objective stated in Healthy People 2000, written in 1990, is to "reduce pregnancies among females aged 15-17," and additional goals include increased abstinence along with reduced activity and increased contraceptive use among those adolescents who do engage in intercourse (U.S. Department of Health and Human Services, 1999a). Similar goals have been proposed for the next decade in Healthy People 2010 (U.S. Department of Health and Human Services, 1999b).

In fact, statistics regarding teen pregnancy are quite startling. Each year, roughly 10 percent of women between the ages of 15 and 19, and 6 percent of women between the ages of 15 and 17, get pregnant (Henshaw, 1999). Approximately half of these pregnancies result in a live birth. The share of teen women who become pregnant per year is considerably higher in the United States than in other developed countries. Rates in England and Canada are one half the level and rates in Japan are one-tenth the level of the United States (Alan Guttmacher Institute, 1998). The high rate of teen pregnancy is a particularly American problem, which rules out the possibility that teens are simply too young to control their sexual activity and/or too shortsighted to use contraception. Social factors must come in to play.

Researchers from many academic disciplines, including anthropology, demography, developmental psychology, and sociology, have contributed to the literature attempting to identify 
the factors that lead to teen pregnancy. From these perspectives, teens' sexual activity and use of contraceptives is governed by their stage of development, which is dependent upon a complicated array of factors influencing them since birth (and potentially even before that). Within this framework, particular acts are viewed as spontaneous and irrational, and teen pregnancies are viewed as "mistakes." Economists have rarely contributed to the study of teen sexual activity and birth control use directly, but have examined the determinants of teen fertility. The contribution of economic analysis in that context is that it provides a focus on the costs and benefits of particular decisions and it applies more sophisticated statistical techniques to the study of the topic.

The purpose of this paper is to review the theory and empirical evidence regarding teens' sexual activity and birth control use with an emphasis on the contribution that economic analysis can make. In the next section I present a series of descriptive statistics designed to document recent trends in these activities for the population as a whole and for racial/ethnic subgroups. The third part of the paper will present a review of prior research, including both theoretical contributions across disciplines and well as previous empirical work that has estimated models of the determinants of sexual activity and birth control use. The fourth section will report an analysis of two data sets that are designed to accomplish two different goals. First, examination of cross-section data can provide correlational evidence regarding who engages in sexual activity and uses birth control. Second, I use state-level data over time attempting to identify whether changes in "prices" affect these activities, where prices are measured by economic conditions, AIDS incidence, welfare generosity, and the restrictiveness of abortion policy. The results of this analysis indicate that some prices do indeed matter; if engaging in sexual activity is "more expensive" through, say, an improved labor market or an increased probability of contracting AIDS, then teenagers are less likely to have sex and/or 
more likely to use contraception. The final section of the paper will review the evidence on the impact of teen child-bearing on the subsequent well-being of women.

\section{RECENT TRENDS}

\section{A. PREGNANCIES, ABORTIONS, AND BIRTHS}

Perhaps part of the recent public attention paid to the sexual activity of teens may be attributable to the rather unusual trends that have occurred over the past decade or so in birth, abortion, and pregnancy rates. As reported in Figure 1A, after years of slowly declining teen birth rates, the late 1980s saw a rather sudden reversal in which the rate of births to women aged 15 to 19 jumped from about 50 per thousand women in this age group to a level of 62 by 1991 . Just as suddenly, that trend reversed and teen birth rates have fallen back to about the level observed before the increase, at 51 births per 1,000 women aged 15 to 19 in 1998. The use of abortion, on the other hand, used to follow inversely the trend in births; decreases in teen birth rates through the late 1980s were matched by increases in the use of abortion services for these women. Over the last decade or so, however, abortions have become less and less common for teens, indicating that since 1991, both abortions and births have fallen simultaneously. If fewer women are aborting and fewer women are giving birth, then it must be the case that pregnancies are falling even more rapidly. In fact, a constructed pregnancy rate (that simply adds the birth and abortion rate and factors in a fixed rate of miscarriages) for teens shows a dramatic decline, falling from 115 pregnancies per 1,000 teenage women in 1991 to 97 in 1996, a 16 percent decline over only five years. Figure 1B shows that similar trends are observed among 15 to 17 year old women. 
These data can be used to decompose the decline in births into one component attributable to risky sexual activity and one to abortion behavior, if we assume that the probability of becoming pregnant if one engages in risky sexual activity, and the probability of a miscarriage are assumed to be constant. Between 1991 and 1996, the birth rate fell from 62.1 to 54.4, a 12 percent decline. If the abortion rate remained unchanged, one would have expected the birth rate to have fallen by 16 percent, or 133 percent of the decline, based on a reduction in risky sexual activity. The fact that abortion became less prevalent offset this effect, increasing the odds of giving birth conditional upon a pregnancy by 4 percent. A similar decomposition can be conducted for the rise in birth rates between 1986 and 1991, when the birth rate rose by 24 percent from 50.2 to 62.1. About two-thirds of this increase may be attributable to a reduction in abortion and one-third to an increase in risky sexual activity.

Although data on abortions are not available by race/ethnicity, patterns in birth rates are quite different across different groups. Figures 2A and 2B show birth rates for 15 to 19 and 15 to 17 year old women, respectively, by race and ethnicity. Any trends in these figures within groups are overshadowed by the huge disparity in teen birth rates across groups. In the peak years of the early 1990s, black, non-Hispanic teens were three times as likely to give birth as white, non-Hispanic teens. Since then, birth rates for all groups have fallen, but the decline for black, non-Hispanic teens has been precipitous. In 1991, 119 teen births per 1,000 women in this group were recorded; in just six years that level had fallen to 91 in 1997, a 24 percent decline. An even greater relative decline occurred for younger black, non-Hispanic teens. In 1990, there were 87 births per 1,000 15 to 17 year old women in this group and this level fell by 28 percent to 63 births. Declines are also observed for Hispanic and white, non-Hispanic teen women over the last few years, but nothing as 
dramatic as that witnessed for black, non-Hispanic teens. The decline for this group is so large that, even though they make up only about 15 percent of all female teens, they account for about 45 percent of the decline in the overall teen birth rate between 1991 and $1997 .^{1}$

The public concern about the level of teen pregnancies and births is perhaps attributable to the fact that the share of teen births that take place outside of marriage has skyrocketed over the past several decades. Figure 3A shows that the fraction of births to unmarried mothers has increased for all women, but particularly so for teens. For nonteens, few births to unmarried mothers occurred until the 1960s and then the fraction grew slowly before leveling off at about one quarter by the 1990s. For teens, on the other hand, 15 percent of births in 1960 were to unmarried mothers, but that rate rose to 78 percent by 1997 . Moreover, racial differences in teen births are dramatic, as shown in Figure 3B. Currently, virtually all births to black teens are nonmarital. ${ }^{2}$

These statistics on teen pregnancies, abortions, and fertility stand in stark contrast to the experiences of other developed countries. Figure 4 reports trends in teen (15-19) fertility rates for the United States, Canada, France, and Japan going back to 1975. Clearly, a high birth rate for teenage women is a particularly American phenomenon. Even in 1975, the teen birth rate in the United States was high, at over 55 births per 1,000 teenage women, relative to the other countries. Canada was the next highest with a rate of only 35 and in Japan there were only four births per 1,000 teenage women. Over the next two decades, however, downward trends are apparent in Canada and

${ }^{1}$ This estimate is based on data presented in Ventura (1995) and Ventura (1999a).

${ }^{2}$ Statistics for whites and blacks are inclusive of Hispanics. Data for white and black, nonHispanics are only available for the last decade or so and are not reported to provide a longer time series. 
France, while Japan remained at a very low level. ${ }^{3}$ By 1997 , the teen birth rate in the United States still stood at about 52 while Canada's rate had fallen to less than half that at 25 . Teen births in France became as uncommon as in Japan over the period. Consistent with these trends, abortions and pregnancies are considerably lower in these other developed countries compared to the United States. Figure 5 shows that pregnancies among teens in the United States are more than twice as common as in Canada and ten times more likely than in Japan. The abortion rate is also three times or more greater than that observed in these other countries, but births still remain considerably higher.

\section{B. SEXUAL ACTIVITY AND BIRTH CONTROL USE}

These trends in births and pregnancies among teens suggest that changes must be occurring in levels of sexual activity and/or birth control use over time. In fact, public pronouncements of such patterns have been put forth by the U.S. Department of Human Services over the last few years. In 1997, Donna Shalala, the Secretary of this Department proclaimed that: "The long-term increase in teenage sexual activity may finally have stopped" (National Center for Health Statistics Press Office, 1997). In 1998, she went further and stated that: "For the first time in two decades, fewer young people are engaging in sexual behavior... It is truly good news for all of us involved in the lives of

${ }^{3} \mathrm{An}$ analysis of the determinants of the decline in Canada and France are beyond the scope of this paper. One potential explanation for the decline, that greater use of abortion has reduced teen fertility, can be ruled out at least for Canada, however. In Canada throughout most of the 1970s and 1980 s, the teen abortion rate was roughly constant at about 15 per 1,000 teen women until a Canadian Supreme Court ruling in 1988 increased its availability (Miller, et al., 1997). Thereafter, the abortion rate rose to 21.5 by 1993 . The timing of this trend is inconsistent with the reduction in teen births displayed in Figure 4. 
America's teenagers" (Centers for Disease Control Press Office, 1998). Both press releases also cite evidence of increased contraceptive use.

Although evidence of such trends does exist, it is not quite as transparent as one would expect based on these assessments. Two main sources of data are used to track trends in sexual activity and birth control use for American teens. The National Survey of Family Growth (NSFG) is administered to women of childbearing age (15 to 44$)$, but is large enough that separate analysis of teens (15 to 19 as well as 15 to 17 ) to track national trends is feasible. Comparable surveys were conducted in 1982, 1988, and 1995. ${ }^{4}$ The second source of data is the Youth Risk Behavior Survey (YRBS), which has been adminstered biannually starting in 1991 to a nationally representative sample of roughly $15,0009^{\text {th }}$ through $12^{\text {th }}$ grade boys and girls. The estimates reported will pertain only to the girls in the YRBS. ${ }^{5}$ All of the statistics displayed in the figures below can be found in Table 1.

These data, however, do not show widespread trends towards lower sexual activity and greater birth control use. ${ }^{6}$ Figure 6A displays the available evidence on the percentage of teens that have engaged in sexual activity in the preceding three months. Although Secretary Shalala's assessment is technically correct that "fewer young people are engaging in sexual behavior," the evidence is not particularly strong. Among those 15 to 19 in the NSFG data (the evidence used to

${ }^{4}$ Earlier NSFG surveys conducted in the 1970s are not comparable because the survey was only administered to married women.

${ }^{5}$ The estimates from the YRBS reported here will be restricted to those for girls for purposes of comparability with the NSFG data. In subsequent analyses of the YRBS reported below, however, I will take advantage of the availability of information on both boys and girls from that survey.

${ }^{6}$ All of the estimates reported here have been computed by the author, but those reported by Abma and Sonenstein (1998) and Terry and Manlove (1999) are comparable. 
support her assertion), a large decline was observed between 1988 and 1995, which followed a large increase between 1982 and 1988. But the 1995 level is only 0.2 percentage points lower than the 1982 level. Moreover, evidence from the same source showed virtually no recent change among those 15 to 17; between 1988 and 1995 the percentage that engaged in sexual activity fell by 0.2 percentage points. Estimates from the YRBS data shows that girls in high school became more sexually active through 1995 before decreasing their activity between 1995 and 1997.

Broad evidence of general declines in sexual activity is also weak when one considers whether or not teens have ever engaged in sexual activity. Figure 6B shows that the YRBS data does indicate a decrease between 1995 and 1997 and the 1997 level is lower than that observed in any of the previous years. The NSFG data shows a very slight decrease in the percentage of ever sexually active women among 15 to 19 year olds between 1988 and 1995, but the rate in 1995 is still almost five percentage points higher than that observed in 1982. Moreover, younger teens continue to be increasingly likely to have ever engaged in sexual activity through 1995.

Estimates of the use of birth control also provide mixed findings for the population as a whole. All statistics regarding birth control use are reported here as the fraction who did not use contraception at a particular incident rather than the more traditionally reported figures of those who did use contraception. This decision was made because it is the failure to use contraception that places the woman at risk of becoming pregnant and that is the focus of this paper. Figure 7A displays the available evidence on the likelihood of failing to use contraception at the last intercourse in the past three months. ${ }^{7}$ Data from the YRBS shows decreases through the 1990s. On the contrary,

${ }^{7}$ It is evident that estimate from the YRBS data are substantially lower rate than that from the NSFG samples. A potential explanation for this finding rests in the particular questions asked in the two surveys. The YRBS appears quite specific in indicating that some form of birth control should 
the NSFG data show an increase between 1988 and 1995 (this information is not available from the NSFG for 1982). A reconciliation is perhaps possible if a dramatic upward trend in the late 1980s followed a sharp rebound in the early 1990s; neither dataset provides sufficient information to test this hypothesis. ${ }^{8}$

The reported increase in the failure to use birth control based on the NSFG data is particularly surprising in light of recent advances in contraceptive technology. Highly effective, longer-term contraceptive methods, including Norplant and Depo Provera, have recently become available. ${ }^{9}$ Although these new methods have been adopted by a significant number of teens, their use has largely been among those who might have used "the pill" otherwise. Figure 7B shows the methods used at last intercourse by women 15 to 19 who have engaged in sexual activity in the past three months. It indicates that 7.7 percent of these women used either Norplant or Depo Provera in 1995 (these methods were not listed as options in 1988). Most other forms of contraception were used at

have been used by asking, "The last time you had sexual intercourse, what one method did you or your partner use to prevent pregnancy?" Estimates from the NSFG are derived from a less-directed approach where respondents are asked whether or not they used a series of contraception types and may have been better able to illicit a response that no form was used. Another potential explanation is that the YRBS is conducted in school while the NSFG is conducted in home and that difference may affect the reporting of sensitive behaviors. Regardless of the differences in levels, estimates over time should still provide trends that can legitimately be compared.

${ }^{8}$ I have spoken with representatives of the CDC about this apparent contradiction. Although they have confirmed finding similar patterns in their own analyses, they also have not been able to resolve the apparent inconsistency across data sources.

${ }^{9}$ This discussion ignores the introduction of the "morning after pill," otherwise known as emergency contraception because such methods were not approved for use by the U.S. Food and Drug Administration until February 1997, beyond the date for which statistics are being reported in this paper. Nevertheless, its use is still uncommon. A recent survey found that only one percent of all women of reproductive age has ever used emergency contraception and that only 11 percent even knew about its existence and that it is available for use (Kaiser Family Foundation, 1997). 
roughly the same rate with the important exception of the pill. In 1988, 41.5 percent of teenage women used this effective form of contraception, but that level fell to 23.3 percent in 1995 . This fall was not compensated by the increased use of new contraceptive methods; the difference is made up by those not using any method at all based on these data.

On the other hand, fewer and fewer teens appear to undertake their first sexual encounter without using contraception. Figure 7C reports these data for both age groups of the NSFG data (no comparable data is available in the YRBS); the reduction has been dramatic. In 1982 more than half of teens in both age groups did not use any contraception at first intercourse. In 1995, however, only about one-quarter failed to do so. Although this trend is important, it is probably not as good a predictor of the risk of becoming pregnant as is birth control use at last intercourse, since the latter is probably a better gauge of typical practices for a larger proportion of sexual activity.

To approximate the risk of pregnancy that a typical teen faces at a point in time, the data on sexual activity in the past three months along with the failure to use contraception at the last intercourse in the past three months are combined to create a statistic representing the joint probability of the two behaviors. This statistic, which I refer to as the "pregnancy risk," constitutes the probability that in the past three months a teenage girl had sex and did not use contraception, placing her at risk of becoming pregnant. It is a useful statistic because it incorporates abstinence as a form of contraception. On the other hand, because it only captures failure to use contraception at the last intercourse, it is likely to understate the fraction of teens who are truly at risk of getting 
pregnant. ${ }^{4}$ Nevertheless, trends in this statistic would seem to be strongly correlated with the true fraction at-risk.

The estimated pregnancy risk across samples over time are reported in Figure 8. As one would expect based on the earlier patterns of sexual activity in the past three months and contraceptive use at the last intercourse over that period, trends in pregnancy risk conflict between the two surveys. The NSFG data indicates an increase in pregnancy risk between 1988 and 1995, but the YRBS shows a decline between 1991 and 1997. Again, these findings may not be inconsistent if an upward trend in the late 1980s reversed in the early 1990s. Nevertheless, they do not present a clear picture regarding changes over time in the risk that teens face of becoming pregnant.

These results for sexual activity, birth control use, and pregnancy risk do not appear to coincide with the evidence on pregnancies and births presented earlier. The rapid decline in these outcomes through the 1990s would certainly suggest that a reduction in sexual activity and an increase in contraceptive use should be readily apparent in these data, but they are not.

To reconcile these findings one needs to recall that the trends in births were considerably stronger for blacks than for whites and Hispanics. In fact, evidence consistent with these trends by race/ethnicity are observed, as reported in Table 1. Several measures of sexual activity for black, non-Hispanic women have decreased rather dramatically, while similar statistics for white, nonHispanic and Hispanic teenage women show no such patterns. For instance, estimates from the

${ }^{4}$ Moreover, the three month window it uses is shorter than the annual window that births, abortions, and pregnancies are typically measured. For both these reasons, a comparison of pregnancy risk to the pregnancy rate will incorrectly make it appear that a huge fraction of teens atrisk become pregnant. 
NSFG indicate that the share of black, non-Hispanic women aged 15 to 19 who have been sexually activity in the past three months fell from 53.6 percent in 1982 to 50.8 percent in 1988 to 45.8 percent in 1995. Similar findings are observed for those 15 to 17 in the NSFG and for school-age girls from the YRBS. Results are less supportive of this trend when considering whether women have ever engaged in sexual activity, but that measure is probably less indicative of the risk of pregnancy than sexual activity in the past three months. On the other hand, little evidence of decreased sexual activity among white, non-Hispanic and Hispanic women is observed in any of the data (if anything, there is evidence of an increase in activity for Hispanics).

Moreover, fewer black, non-Hispanic women engage in sexual activity without using contraceptives. At first intercourse, rates of use have jumped significantly for all demographic groups. But contraceptive use at the last intercourse in the past three months has risen strongly only for black, non-Hispanic women. In the YRBS, for instance, one-quarter of school-age girls in this group failed to use birth control at their last intercourse in 1991, but that rate fell continuously to 18 percent by 1997. Perhaps most striking is the evidence on the constructed pregnancy risk measure. For both the younger teens from the NSFG between 1988 and 1995 and for the school-age teens in the YRBS between 1991 and 1997, the risk of pregnancy was almost cut in half. Based on all of the above findings, one can see that the national trend towards lower teen birth rates is largely driven by a reduction in births to black, non-Hispanic women and the trend for that group is consistent with their reduction in sexual activity and increased reliance on contraception, reducing their risk of becoming pregnant. 


\section{REVIEW OF THE LITERATURE ON TEEN SEXUALITY}

The models of the determinants of teen sexuality and use of contraception that economists have put forward are considerably different from those introduced in the other social sciences. This section will provide a brief overview of these perspectives and offer a framework for characterizing their differences. I will then describe recent advances in the field of behavioral economics that can provide something of a synthesis of the two contrasting approaches. Finally, I will briefly review the empirical literature that attempts to identify those factors that are related to sexual activity and contraceptive use.

\section{A. ALTERNATIVE THEORETICAL PERSPECTIVES}

The models to which noneconomists subscribe tend to be very intricate and factor in the effect of a multitude of potential components that affect developmental outcomes, including teen sexuality, and may well affect each other (c.f. Brooks-Gunn and Furstenberg, 1989; Hardy and Zabin, 1991; Brooks-Gunn and Paikoff, 1997). For instance, Hardy and Zabin (1991) present a life course model in which these factors are broadly decomposed into those which are biological or health-related and those which pertain to one's environment or family. Each of these categories contain a large number of factors. Within biological/health factors, indicators of the child's health go back from before birth (i.e. mother's nutritional status, drug use, etc.), through infancy and childhood (i.e. congenital deficits, accidents, nutrition, etc.) and into adolescence (i.e. sexual maturation, mental health, etc.). Family and environmental factors include characteristics of the individual's parents and family (i.e. parents' education, parenting skills, family composition, etc.), available resources (i.e. economic, support networks, etc.), community characteristics (i.e. crime, 
education quality, family patterns, etc.) and peers and the media (i.e. friends' characteristics, exposure to movies/TV, etc.). These factors are allowed to interact with each other. Beyond this extensive set of characteristics, other factors, such as stressful life events, are also included in the model. All of these components contribute to a complex process by which developmental outcomes of children, such as teen sexual activity, are determined.

Economic models, in contrast, rely upon the rationality of the individual decision-maker; decisions are made based upon a comparison of the benefits and costs of the alternatives (c.f. Leibowitz, et al., 1986; Lundberg and Plotnick, 1995; and Kane and Staiger, 1996). ${ }^{7}$ Interestingly, specific models of sexual activity and birth control use are rarely provided. The literature on fertility in general, and teen fertility, in particular, traditionally includes models that begin with the decision to become pregnant, simply treating abstinence from sex as the ultimate means of avoiding an undesirable pregnancy. Within this framework, women "choose" to become pregnant if the benefits of a pregnancy are greater than its costs. These costs typically involve what one gives up by becoming pregnant, which are lower if, for instance, welfare benefits are higher or labor market conditions are weaker. A similar approach of comparing costs and benefits may be applied to the specific decision to engage in sexual activity or to use contraception among those who are sexually active.

This framework is best represented in the form of a "game tree," as shown in Figure 9. Women are presented with a set of decisions that must be made and each decision leads to a new "branch" of the tree in which additional decisions are required. In the context of fertility behavior,

${ }^{7}$ Akerlof, Yellen, and Katz (1996) provide an alternative type of economic model that describes bargaining power between men and women within relationships to propose an explanation for the growth in non-marital births over the past few decades. 
women must choose whether or not to engage in sexual activity. Those who do so must decide whether or not to use contraception. Their decision at this stage leads to varying probabilities of becoming pregnant (defined here to be $\mathrm{p}_{1}$ if they use contraception and $\mathrm{p}_{2}$ if they do not where $\mathrm{p}_{2}$ is greater than $\mathrm{p}_{1}$ ), but in both cases it is possible that a pregnancy would result. ${ }^{8}$ If pregnant, the woman must decide whether or not to abort her pregnancy or carry it to term, and chooses to give birth with probability $\mathrm{p}_{\mathrm{b}}$. A more complicated version could also include the decision to get married, which enters the decision tree at various points (for instance, before the decision to engage in sexual activity or after a pregnancy results).

This representation of the decision-making process is not exclusive to economics, since the diagram itself may be thought of as simple sequencing of events. The difference between economics and other disciplines is that economists associate with each outcome a particular cost and benefit that individuals take into consideration in their decision-making. In fact, the costs and benefits incurred at the later stages are assumed to be taken into consideration when decisions are made at the earlier stages of the game tree. For example, if abortion policy becomes more restrictive and, hence, more expensive to teens, then these costs should be incorporated into the decision regarding whether to engage in sexual activity.

${ }^{8}$ In the decision tree represented in Figure 9, the actual payoff if one engages in sexual activity and becomes pregnant is the same regardless of whether or not contraception was used (equal to B). One could argue that psychic costs would be greater if birth control was used, but this simplification does not affect the analytical framework and is maintained here. Similar arguments could be made regarding the actual payoffs to giving birth or aborting (equal to $\mathrm{C}$ or $\mathrm{D}$ ). 


\section{B. COMPARISON AND SYNTHESIS OF MODELS}

An important distinction between the economic and non-economic models involves the degree to which an adolescent girl has the ability to make rational decisions (Lowenstein and Furstenberg, 1991). Developmental models of sexuality describe a series of stages in which girls age through puberty, adolescence, and their later teenage years with a greater ability to make such decisions. For most girls, in their earlier teenage years this ability is limited, according to these models, and sexual encounters tend to be spontaneous. These beliefs are expressed by Moore, et al. (1995), who write:

There is abundant evidence ... that sex is irrational, in the sense that it is often not planned, but impulsive. This is especially true for first sexual experience. Another way that the data seem to support a 'sex as irrational' premise is the pattern of time inconsistency, in which teens (and others) often plan to 'just say no' but end up saying 'yes,' and most teens think the best age to begin having sex is later than the age when they began.” (p.11)

Within this framework, teen pregnancies are viewed as unavoidable mistakes. The economics literature may express concern regarding teens' abilities to make rational decisions, but typically circumvents the problem by arguing that the difference between teens and adults is that teens have a "higher rate of time preference," through which the benefits incurred at the moment are valued more highly than the (potentially) high costs that may be incurred some time in the future (c.f. Leibowitz, et al. 1986).

Recent advances in the field of behavioral economics may provide an appropriate middle ground in which the two sets of models may be reconciled. For instance, O'Donahue and Rabin 
(1999) present a model of behavior in which rational individuals make decisions based on the relevant benefits and costs, but may still choose to act in ways that appear to be spontaneous. In their model, the benefits and costs that are incurred in the future are discounted in the same way as they would be in standard economic models, but individuals place heightened value on those rewards received right at the moment. Based on such a model, engaging in unprotected sexual activity today would be more likely since today's benefit is disproportionally weighted even in the face of potentially large future costs. On the other hand, teens may still state a preference not to engage in sexual activity at some future point because the heavy weight placed on immediate gratification would be absent. This sort of model maintains the assumption of rationality in that individuals are maximizing their utility, but it also allows for a form of spontaneity. In fact, such a model would yield additional predictions that are consistent with those from other fields. One would expect that as teens get older and gain experience regarding their sexuality, they may be able to make more forward-looking decisions (like acquiring birth control) so that they are not placed in a position where immediate desires overrule longer-term costs.

\section{EMPIRICAL CORRELATES}

An extensive review of the literature on teen sexual activity, contraceptive use, and fertility is available in Moore, et al. (1995). Their review uncovers a multitude of factors that have been found to be correlated with the initiation of sexual activity, including: older age, age at menarche, pubertal status, frequent church attendance, supportive family relationships, educated parents, school performance, living in a single parent household, using alcohol or other drugs, dating young and having sexually active siblings and friends. Similar characteristics are related to contraceptive use 
at first intercourse. The emphasis on factors such as these are consistent with non-economists' models of teen sexual activity in that a complex array of inter-related factors that affect a child's development should also be related to their sexual behavior.

Unfortunately, statistical difficulties plague the interpretation of many of the results as being causal. In particular, many of the variables considered are either jointly determined with sexual activity and contraceptive use or are correlated with other unobservable factors that may also be related to these behaviors, preventing a causal interpretation. For example, the factors that influence drug and alcohol use are also likely to influence decisions to engage in sexual activity and use birth control. ${ }^{9}$ Therefore, finding a positive relationship between drug or alcohol use and, say, sexual activity does not imply that drinking may lead one to have sex. Alternatively, children raised in families that invest less in them (in the form of time or other resources) may be more likely to become sexually active and to perform worse in school. Such a relationship would invalidate a causal interpretation of the effect of school performance on sexual activity.

Economists have rarely conducted empirical studies regarding sexual activity and contraceptive use, but have more commonly studied the determinants of fertility with a particular emphasis on the impact of policies that alter the costs of having children. This emphasis is consistent with an economic model that emphasizes rationality and the fact that one might expect to observe behavioral responses to changes in the incentives facing individuals. I will focus this review on those costs that can be considered as determinants of sexual activity and contraceptive use, including labor market conditions, AIDS incidence, abortion access, and welfare policies.

\footnotetext{
${ }^{9}$ Recent work by Dee (1999), however, has specifically dealt with the econometric problems in this particular example.
} 
Regarding labor market conditions, Butz and Ward (1979) and Macunovich (1995) estimated the relationship between the gains from work for women and their level of fertility, although neither of these papers focuses specifically on teenage women. Although Butz and Ward report evidence supporting the proposition that the timing of child-bearing is negatively correlated with changes in earnings, Macunovich disputes their finding because of data and econometric problems. In particular, she argues that wage changes bring about both income and substitution effects that make it difficult to predict the optimal response to a change in the wage. A higher wage increases the return to work (the substitution effect), but also provides additional income that can enable one to "consume" more (the income effect). Below, I will evaluate the responsiveness of fertility to changes in job availability (through the employment-to-population ratio), not the wage. Since the impact of labor market conditions on the decision to bear children for those without jobs is solely a function of the substitution effect, one might predict that an improved labor market would lower the teen fertility rate.

The impact of the AIDS epidemic on sexual behavior was not considered to be within the domain of economics until the work of Philipson and Posner (1993) and Ahituv, Hotz, and Philipson (1996). These papers argue quite forcefully that economics studies the response of individuals to incentives and AIDS provides a strong incentive for those potentially at risk of AIDS to alter their sexual practices in response. They also find empirical evidence supporting the position that those most at-risk of contracting AIDS have indeed become more likely to engage in safe sex. Although these papers do not focus on teens, the fact that most teen sexual activity occurs outside of marriage and potentially with multiple partners, implies that one could extend their analysis to indicate that 
teens should either become more likely to practice abstinence or to become more likely to use condoms should they be sexually active.

Research on the effects of abortion access on fertility behavior has grown considerably over the past few years (c.f. Levine, et al., 1996; Kane and Staiger, 1996, and Matthews, et al. 1997). Earlier research on abortion access had restricted its focus to the effect on abortion demand, and the results generally supported the notion that the demand curve for abortion services is downward sloping; an increase in the cost reduces the demand (c.f. Blank, et al., 1996; and Haas-Wilson, 1996). The major advance in more recent work is that it provides empirical tests of the proposition that changes in abortion access could also affect the likelihood of pregnancy. Results typically confirmed that restricted abortion access lowered the demand for abortion services, but found no evidence of an increase in births, which must mean that pregnancies declined. One could then infer that sexual activity and/or contraceptive use was affected, but no direct test of these behaviors was provided due to data limitations.

Economists have long been contributors to the research on the effects of welfare generosity on non-marital fertility; that literature is reviewed by Moffitt (1998). He states that the conventional wisdom based on the existing evidence earlier in the decade was that welfare receipt had no impact on fertility behavior, but that more recent work suggests that a relationship may indeed exist. Little of this work is directed specifically at teenagers, but a disproportionate share of welfare recipients began their spells by giving birth as teens, suggesting we may expect to see some effect for teens as well. To date, relatively little research has examined the impact of welfare reform on teen fertility. Most of the recent work that has been conducted has focused on the results of one particular provision, the family cap, among many reforms instituted simultaneously. The family cap eliminates 
the benefit increase that otherwise would result if a woman on welfare had an additional child. Research on the family cap has also provided mixed evidence regarding its impact (Argys, et al., forthcoming; Fairlie and London, 1997; O’Neill, 1994; and Camasso, et al., 1999). The only work of which I am aware that has examined the impact of a wide-ranging set of welfare reforms is that by Horvath and Peters (1999), who find that the introduction of reforms led to declines in nonmarital fertility among teens. Additional research supporting this finding would be required, however, before one could make strong conclusions regarding the effect of welfare reform on teen fertility.

An important implication of these findings is that evidence does seem to support the position that changes in the costs of childbearing affect teen fertility behavior. This has obvious implications for teen sexual activity and birth control use, but direct evidence of such effects is largely unavailable at present. Part of the subsequent empirical analysis will address this omission in the literature.

\section{EMPIRICAL ANALYSIS}

\section{A. ANALYSIS OF DEMOGRAPHIC CORRELATES}

This part of the paper will employ cross-sectional data to analyze the individual factors that are related to sexual activity and use of contraception among those who have engaged in sexual activity. The data to be employed here is the first wave of the National Longitudinal Survey of Adolescent Health (“Add Health”), which was conducted in 1994/1995. The public release version of these data contains information on 6,504 boys and girls in grades 7 through 12 . Tremendous

detail is available on these individuals, including demographics, scores on a test of cognitive ability (the Peabody Picture Vocabulary Test, or PPVT), grades in school, characteristics of the child's 
mother and household, and extensive attitudinal variables, which will be used here to determine the correlates of teen sexual activity and use of contraception. ${ }^{10}$

Results of this analysis are reported separately for girls and boys in Tables $2 \mathrm{~A}$ and $2 \mathrm{~B}$, respectively. The first row of these tables provides estimates of the percentage of students who engaged in sexual activities that may lead to a pregnancy. Responses for boys and girls are generally similar. ${ }^{11}$ For the full sample, 37.6 percent of girls and 38.9 percent of boys have ever had sexual intercourse and 35 percent of the girls and 34 percent of the boys have done so in the past three months. Roughly one-third of sexually active girls and boys failed to use contraception at first intercourse as well as in their last sexual encounter in the past three months. The risk of pregnancy based on the behaviors of women in the past three months is estimated to be 12.4 percent. For boys, the risk of a partner's pregnancy is 10.3 percent. Among just those boys and girls age 15 and over, sexual activity is somewhat more common, but contraceptive use is not.

The remainder of Tables $2 \mathrm{~A}$ and $2 \mathrm{~B}$ presents probit estimates of the relationship between each of these outcomes and a series of characteristics of teens and their families. Two separate models are estimated here for each of the five different outcomes. The first includes the full sample of girls and boys and includes just demographics and mother's/household characteristics, which are more likely to be exogenous to the behaviors being studied. Responses to attitudinal/expectational

\footnotetext{
${ }^{10}$ Characteristics of mothers were obtained from a separate parental questionnaire. Interviewers were clearly informed to attempt to gather information from the respondent's mother (or other mother-type figure), not the father, and the vast majority of parents responding to this part of the survey were mothers. The sample is limited to those students between the ages of 12 and 18 .

${ }^{11}$ One reason why this finding may not be obvious is that about one-third of the partners of sexually active women age 15 to 17 is two or more years older than they are (Darroch, Landry and Oslak, 1999).
} 
questions are also considered in the second model, but the sample is restricted to those between the ages of 15 and 18 since many of these questions were only asked of this older group. ${ }^{12}$ These variables are examined separately because teens' responses to these questions may be influenced by their behavior (that is, they are endogenous).

For girls (Table 2A) estimates from models of sexual activity are quite similar regardless of whether the activity relates to the past three months or ever. Many of the girls' characteristics are significantly related to sexual activity, which is more likely among those who are older, in a higher grade, perform worse in school, are a religion other than Catholic, and who do not attend religious services on a weekly basis. An additional year of age and of schooling increases the likelihood of having sex by 6 to 8 percentage points depending upon the measure of sexual activity and the age composition of the sample. Every additional one-tenth of a point in a girl's GPA reduces her likelihood of sexual activity by 11 to 14 percent. On the other hand, once one controls for the girl's own characteristics, few of the attributes of her mother or household are significantly related to sexual activity.

In models that include potentially endogenous variables representing attitudes, expectations, and risk perceptions, these variables are also observed to be significantly related to the likelihood of sexual activity. Girls who report that getting pregnant would be one of the worst things to happen to them are roughly 20 percentage points less likely to engage in sexual activity. Both measures of parental disapproval yield similar estimates. On the other hand, those who view little or no risk of pregnancy from sexual activity over an entire month are 13 percentage points more likely to have

${ }^{12}$ I have also estimated models for those aged 15 to 18 excluding the attitudinal/expectational variables for purposes of comparison with the first set of models in Tables 2A and $2 \mathrm{~B}$ and obtained similar results. 
sex. Of course, the concern regarding interpretation of these relationships as being causal is that, for instance, girls who regularly engage in sex may downplay their concerns regarding a pregnancy, the level of their parents' disapproval, or their perceived risk of pregnancy to be consistent with their own behavior.

Compared to models of sexual activity recently or ever, results from models of contraceptive use indicate some differences in the factors that are correlated with a girl's behavior. In fact, in a multivariate context, very little is significantly related to contraception at first intercourse. Black, non-Hispanic girls are less likely to fail to use contraception, as are those who score higher on the available aptitude test score. Those who report no religion are significantly less likely to have failed to use contraception. In models that include attitudinal/expectational measures, girls who reported their mothers disapproved of birth control use and those who perceived there to be little or no probability of getting pregnant after a single act were more likely to have failed to use contraception as well. Among the multitude of other characteristics reported, none of the others are found to be significantly related to contraceptive use at first intercourse. Ironically, girls who report that getting pregnant would be one of the worst things that could happen to them were no more likely to use contraception than others.

Models of failure to use contraception at last intercourse, on the other hand, find that many personal and family background characteristics are important correlates. Test scores, religion, mother's education, receipt of public assistance, and family income are all found to contribute to the failure to use contraception at last intercourse. Many of the attitudinal/expectational variables are significant as well. In fact, those women who report that getting pregnant would be the worst thing 
that could happen to them are 20 percentage points less likely to have failed to use contraception (i.e. more likely to use contraception) at their last intercourse.

A potential explanation that would be consistent with the divergent findings between the two measures of contraceptive use could involve the spontaneity of the act. If first intercourse is more likely to be an unplanned event, then contraceptives would be more likely to be used randomly. On the other hand, once girls begin having sex more frequently, the activity becomes more planned and appropriate precautions may be more likely to be used by those who want to take them. Such an interpretation is consistent with the earlier discussion of the contribution of economics to modeling sexual activity in that spontaneity does not need to be ruled out, but once the activity becomes repeated one would expect a greater degree of rationality.

The final set of models reported in Table 2A report the factors related to a teenage girl's "pregnancy risk," which I have defined as the likelihood that a girl has had sexual intercourse in the past three months and did not use contraception at her last intercourse over that period. Econometric models of pregnancy risk have important advantages compared to the more traditional approach of separately examining sexual intercourse and the use of birth control. First, estimates of the relationship between a personal characteristic and sexual activity may contradict the estimated relationship between that characteristic and the use of contraception, making it more difficult to determine whether a girl with that trait is more or less likely to be at risk of becoming pregnant. For instance, among the full sample of Add Health respondents, those who attend religious services at least once per week are less likely to have engaged in sexual activity in the past three months (reducing their pregnancy risk), but those who did have sex were less likely to use contraception 
(increasing their pregnancy risk). Estimates from the pregnancy risk models can indicate which of the two effects dominates, or if the two are perfectly offsetting. ${ }^{13}$

Moreover, estimates from models of contraceptive use among the sample of respondents engaging in sexual activity are subject to sample selection bias. For instance, suppose that the AIDS epidemic led many risk-averse individuals to choose abstinence over sexual activity with some form of contraception. If the less risk-averse did not change their behavior, the sample of sexually active girls would contain a larger fraction of those who do not use contraception and one might inappropriately conclude that AIDS reduces the use of birth control. A model of pregnancy risk for which the target population is all teenage girls avoids this selection problem.

Results from these models are reported in the final two columns of Table 2A. For the full sample they indicate that pregnancy risk increases with age, having a working mother, and having a mother who receives public assistance, and falls with school performance, being Catholic, and being at the top of the income distribution. In the model of older teens that include potentially

${ }^{13}$ Of course, one could also derive the impact of the two separate effects on the pregnancy risk. To see this, define the share of respondents who have had sexual intercourse in the last three months to be: $\mathrm{P}(\operatorname{sex})=\mathrm{S} / \mathrm{N}$ where $\mathrm{S}$ is the number having sex and $\mathrm{N}$ is the sample size. Then define the probability of failing to use contraception conditional on having sex as: $P($ fail $)=F / S$ where $F$ is the number failing to use contraception. Then the risk of pregnancy, $\mathrm{P}(\mathrm{preg})=\mathrm{P}(\mathrm{sex}) * \mathrm{P}($ fail $)=\mathrm{F} / \mathrm{N}$. The derivative of $\mathrm{P}(\mathrm{preg})$ with respect to any variable, $\mathrm{X}$, is obtained by the product rule:

$$
\frac{\partial[P(\text { preg })]}{\partial X}=P(\text { fail }) * \frac{\partial[P(\text { sex })]}{\partial X}+P(\text { sex }) * \frac{\partial[P(\text { fail })]}{\partial X} .
$$

Standard errors for these estimates would have to be calculated using the delta method. Defining a pregnancy rate and then estimating models of its determinants directly is much simpler. Estimates from these pregnancy risk models may differ slightly from the formula just derived because Probit derivatives are estimated at the value of the sample mean for each variable, rather than estimating separate derivatives for each person and then taking the mean. 
endogenous variables, the results further indicate that pregnancy risk is lower for those who view a pregnancy as one of the worst things that could happen to them and whose mothers disapprove of them having sex at this time. The perception that pregnancy is unlikely is positively associated with pregnancy risk, but the estimate is not statistically significant.

Estimates from comparable models for boys are presented in Table 2B. Regarding sexual activity, a few relevant distinctions in the results for between boys and girls are noteworthy. First, racial differences are far more pronounced among the boys than the girls. For instance, black, nonHispanic boys are 25 percent more likely to report having engaged in sexual activity ever relative to white, non-Hispanic boys. The comparable gap for girls is only 10 percent. Second, in models that include attitudes and expectations, boys who report that their friends will respect them more if they have sexual intercourse are 10 percentage points more likely to have engaged in sexual activity. No such effect is observed for girls. Here, in particular, it is important to raise the caveat of endogeneity in attitudes. Regarding contraceptive use at last intercourse, the main difference between boys and girls is the influence of mother's characteristics. In particular, mother's educational attainment and welfare receipt are important determinants of contraception use at last intercourse for girls, but not for boys.

\section{B. ANALYSIS OF "PRICES"}

This section of the paper will examine the impact of increases in costs associated with becoming pregnant and giving birth on teenagers' patterns of sexual activity, contraceptive use, and pregnancy risk. These costs can be thought of as an increase in the price of having sex and/or failing to use contraception and can be monetary or otherwise in nature. The hypothesis that is being 
examined here is that increases in the cost will reduce the likelihood of having sex and increase the likelihood of using contraception.

The specific costs that I will use in this analysis include labor market conditions, the incidence of AIDS, the generosity of the welfare system, and abortion restrictions in place in a teenager's state of residence. ${ }^{14}$ Labor market conditions represent a price in the form of an opportunity cost. In periods when job opportunities are limited, the cost of becoming pregnant is lower because the opportunity cost associated with a reduced ability/willingness to work is lower at that time. The incidence of AIDS represents a clear cost since greater levels of sexual activity without the use of condoms can impose substantial health risks. If welfare benefits are more generous and/or easier to get, the cost of a pregnancy is lower because the government will pay some modest living expense in that event. Finally, restricted abortion access may reduce one's ability to abort an unwanted pregnancy, making it more costly to become pregnant in the first place. The estimated impact of these costs on fertility behavior based on past research was reviewed earlier. To the extent that they are related to fertility, they may also be related to sexual activity and birth control use, yet no previous research of which I am aware examines these relationships.

\footnotetext{
${ }^{14}$ Another potential policy variable that could be important in determining sexual activity and contraceptive use is sex education in schools, which could reduce information deficiencies for teens making these decisions. For instance, Oettinger (1999) uses data on individual enrollment in sex education classes and finds that taking such a class increases the likelihood of becoming sexually active earlier, but has only a weak effect on the likelihood of an earlier pregnancy. I have chosen not to consider sex education in the present analysis for two reasons. First, I am unable to identify enrollment in sex education classes for individuals in the YRBS data and I have been unable to piece together state-level data for sex education requirements for all the survey years available. Second, as described below geographic identification using the YRBS data is limited because of the number of states repeatedly covered by the survey, suggesting that a more parsimonious specification may be preferable.
} 
In the subsequent analyses, for purposes of completeness all models will be estimated separately for boys and girls. ${ }^{15}$ Although most of the costs considered would affect girls more than boys (with AIDS being a possible exception), it is unclear how these costs would be related to boys' sexual activity. On the one hand, one might consider boys to act something like a control group. If costs that are imposed only on girls have an estimated effect on the sexual activity of both boys and girls, then perhaps the finding is spurious. Alternatively, because high school boys are the likely (but not exclusive) sexual partners of high school girls, one may expect to see spillovers in the sense that if something affects girls' likelihood of engaging in sexual activity, it will also affect boys' likelihood.

To determine whether sexual activity and birth control use are related to their costs, I use 1991, 1993, 1995, and 1997 YRBS data, described previously. Although personal characteristics of the respondents in these data are quite limited, its particular advantage for the present purpose is the availability of state of residence identifiers for each respondent. This information allows me to link state level data for the relevant year on the costs examined. I obtained state-level employmentto-population ratios for teenagers directly from the U.S. Bureau of Labor Statistics. ${ }^{16}$ The data on AIDS incidence come from the Centers for Disease Control and measures the number of AIDS cases

${ }^{15}$ Obviously, boys face no "pregnancy risk" themselves, but do face the risk of getting a girl pregnant. For ease of exposition, in the remainder of the discussion I will discuss pregnancy risk symmetrically with the implication that for boys it should be interpreted in the appropriate way.

${ }^{16}$ These data reflect unpublished estimates from the Current Population Survey (CPS) and were provided directly from the Local Area Unemployment Statistics division of the Bureau of Labor Statistics. 
per 100,000 population in the state (c.f. U.S. Department of Health and Human Services, Public Health Service, Centers for Disease Control, various issues). ${ }^{17}$

Data on welfare generosity take two forms. First, I use the maximum welfare benefit for a family of two under the AFDC or TANF program depending upon which was in place in each year; these data were obtained from the Green Book (U.S. House of Representatives, various years). Second, I create an indicator variable that identifies whether or not a state has a "reformed" welfare system. These reforms could have come about either through waivers requested by states and granted from the federal government before national welfare reform in 1996 or by the state implementing a valid TANF plan after national welfare reform. ${ }^{17}$ These data were obtained from the Council of Economic Advisers (1999).

The final set of variables is a series of three indicator variables that represent whether or not a particular type of abortion restriction was in place in a particular state and year. The three specific restrictions I consider are Medicaid funding restrictions (which largely prohibit the use of public funds for abortions), parental consent/notification laws (which require a minor to either notify or obtain consent from a parent before obtaining an abortion), and mandatory waiting period laws (which requires a woman seeking an abortion to wait, typically, 24 or 48 hours before having an

\footnotetext{
${ }^{17}$ The definition of AIDS changed beginning in 1993, leading to a large increase in the number of cases counted. In the data used for this paper, I have adjusted the 1991 data by estimating a cubic trend in AIDS incidence rates and using the discrete jump between 1992 and 1993 as the scaling factor. The results presented are generally similar (although less precise) to that obtained when I only use 1993 through 1997 data.

${ }^{17}$ The determination of whether a waiver was in place is based upon the waiver's implementation date, not the date the waiver was requested. For those years in which a waiver or a TANF plan was implemented in the middle of the year, I use the fraction of the year in which the reform was in place.
} 
abortion performed after notifying a provider of her intent to abort). These data were obtained from the National Abortion and Reproductive Rights Action League (NARAL) Foundation (various years).

Using these data, I estimate Probit models with state and year fixed effects where the dependent variables are the the sexual activity/contraceptive use measures described earlier and the explanatory variables include a vector of prices along with the limited personal characteristics available for each respondent. In such a model, the identification of price effects is obtained by comparing changes between states over time. All reported results from the Probit model represent the value of the derivatives estimated at the sample mean of the independent variables.

Although the YRBS is the best-suited dataset to estimate such a model because of its multiple survey years and available state identifiers, it does have some limitations. In particular, the survey is school-based and, although the sample is relatively large (between about 11,000 and 16,000 teens per year) and is chosen to be nationally representative, its school-based nature leads the respondents to be more concentrated geographically. In fact, in any given year only about half of the states are represented. Of course, the larger states like California and New York are represented in each survey; some of the smaller states appear much less frequently, if at all. For instance, over the four survey years, only 41 states (including the District of Columbia) are included at all and 13 states are only represented once. In a model with state fixed effects, this latter group of states offers no additional identification because no change can be observed within the state over time. In fact, only 11 states are represented in each survey year. ${ }^{18}$

${ }^{18}$ These states are: California, Colorado, Florida, Georgia, Michigan, Mississippi, New York, Ohio, Pennsylvania, Texas, and Washington. To examine the impact of the findings from using an unbalanced sample, I have also estimated all reported models separately for just the 11 states that 
Moreover, a model with state fixed effects is only identified based on changes within states over time. For those policy variables that are discrete in nature, such as abortion restrictions, the power of the analysis may be limited because so few changes have taken place over the sample period within these states. ${ }^{19}$ Although continuous price measures like the employment-to-population ratio and AIDS incidence provide greater variation, the power of an analysis of welfare generosity may also be limited in that very few states substantially changed the nominal value of their benefits over the sample period in the available states. This caveat should be kept in mind in interpreting the results reported subsequently.

The results of this analysis are reported in Table 3. The first row of this table indicates the percentage of respondents who are engaging in each of the specified outcomes. Differences do emerge when comparing these estimates to those found from the Add Health data. Some, but not all, of these differences may be attributable to the fact that YRBS sample (high school students) is slightly older than that in Add Health (grades 7 through 12). After adjusting for age by focusing on the older Add Health respondents, those in the YRBS appear less likely to report sexual activity in the last 3 months, that they failed to use contraception at last intercourse in the past three months, and are at less risk of pregnancy. These differences may be to differences in survey procedures.

The remainder of Table 3 presents estimates of equation (1) where the outcomes represent indicator variables of sexual activity, birth control use, and pregnancy risk. Estimated coefficients

are represented in each survey year. Except where discussed below, all results from this subset of the data are qualitatively similar to those reported for the full sample.

${ }^{19}$ In only three, seven, and six states are changes observed between the first and last available survey year available in Medicaid funding restrictions, parental consent/notification laws, and mandatory waiting periods, respectively. 
for the demographic variables are generally consistent with those obtained in the analysis of Add Health data. For girls, for the geographic variables representing differences in prices, estimated effects of differences in the employment-to-population ratio provide support for the hypothesis that prices matter. A one percentage point rise in this ratio (which represents an increase in the cost of a pregnancy) is predicted to reduce the likelihood of sexual activity ever or in the past three months by about 1 percentage point (columns 1 and 3). The likelihood of failing to use contraception is estimated to fall by 1.1 percentage point (column 5). Combining these two effects, the risk of pregnancy is estimated to fall by 0.2 percentage points (column 7). To put these numbers in perspective, the teen employment-to-population ratio rose from an annual average of 41.9 to 43.5 from 1991 to 1996 and would be predicted to have reduced the risk of pregnancy by 0.3 percentage points, or 5 percent using the average risk of pregnancy of 6.2 percent as a base. In comparison, pregnancies are estimated to have fallen by 16 percent from 1991 to 1996, as reported earlier.

For boys, a stronger labor market is estimated to lead to less frequent sexual activity, but not contraceptive use. Point estimates indicate that the effect on sexual activity is smaller for boys than it is for girls, which is consistent with the notion that some, but not complete, spillover might be expected in the behavior of high school boys and girls.

Some support for a price effect is also found in the estimates of the effect of AIDS incidence. Here, results indicate that AIDS is negatively and significantly related to a girl's likelihood of ever having sexual intercourse (i.e. positively related to abstinence). Abstinence is the strongest response one could have to the fear of contracting AIDS. For those who are sexually experienced, I find estimated effects on sexual activity in the past three months and contraceptive use that are not statistically significant. One might suspect these effects to be weaker than that regarding abstinence 
since once one decides to engage in sexual activity in the presence of AIDS, they may be less likely to substantially reduce that activity. Moreover, among those using contraception, they may have been more likely to switch to condoms, but this does not represent an increase in the use of contraception and would not be captured by this model. In terms of pregnancy risk, estimates in Table 5 suggest that greater AIDS incidence in a girl's state reduces her risk, but not significantly. ${ }^{20}$ Regarding welfare generosity, results provide mixed support for the role of prices. Welfare benefits do appear to be positively related to the likelihood of sexual activity and the failure to use birth control for both boys and girls. A 10 percent increase in welfare generosity is estimated to raise the risk of pregnancy by 1.2 percent for girls and 0.7 percent for boys. On the other hand, some of the results regarding the impact of welfare reform are counterintuitive. For instance, teens residing in states that reformed their welfare system were more likely to engage in sexual activity than girls in other states. Almost universally, welfare reform in a state meant increased difficulty for women to collect benefits, which would have been predicted to reduce sexual activity. Taking into account birth control use, the results indicate that effect of welfare reform is positive and marginally statistically significant for girls. One potential explanation for these findings is that the reform initiatives may have been endogenous in that the states that were experiencing the biggest increases in teen sexuality were the ones most concerned about the potential caseload growth in the future and, therefore, were more likely to crack down sooner on welfare receipt.

\footnotetext{
${ }^{20}$ On the other hand, when the sample is restricted to the 11 states for which data are available for all 4 survey years, estimates indicate that a 10 case per 100,000 increase in AIDS incidence reduces the probability of pregnancy risk for girls by 0.9 percentage points, which is significantly different from zero (results available upon request). Since this analysis is based upon 11 of the largest states, this sample may be more representative of the locations where AIDS is a greater threat.
} 
The results regarding abortion restrictions find little evidence that the imposition of a restriction has any effect on teen's sexual activity, use of birth control, or pregnancy risk. A potential explanation for this finding is the lack of power inherent in the statistical methodology, as described earlier. This problem may be attributable to the limited sample of states and the pattern of changes of abortion restrictions across states. Of the three types of restrictions considered, there were relatively few changes made over the sample period and those changes were more likely to occur in smaller states that were not in the sample each possible year. Therefore, the ability to obtain precise before and after differences to compare to other states is limited and may have contributed to the general weakness in the findings along this dimension.

Ihave also estimated a model analogous to that in equation (1) that includes interaction terms between each price variable and the race/ethnicity of each respondent. Since trends in sexual activity and contraceptive use differed so dramatically by race/ethnicity (and particularly for black, nonHispanics), one might expect these price effects to have differential impacts as well. Table 6 reports the results of this analysis when all observations are used in the analysis separately for boys and girls. Identification in these models is weakened by the fact that sample sizes within states/years by race/ethnicity begin to get small, so imprecision plagues many of the results.

Nevertheless, some important differences emerge. In particular, the impact of labor market conditions is found to be greater for black, non-Hispanics than for white, non-Hispanics. For girls, an improvement in the employment-to-population ratio is found to have a significantly stronger effect on the likelihood of using contraception. The magnitude of the effect of labor market conditions on pregnancy risk is twice as great for blacks than for whites; the difference is significant at the 10 percent level. Racial differences for boys are even more dramatic; pregnancy risk is found 
to be roughly unaffected by labor market conditions for white, non-Hispanic boys, but a strong negative effect is observed for black, non-Hispanic boys. Some evidence also supports the position that the generosity of welfare benefits has a larger impact on black, non-Hispanics than for white, non-Hispanics. Again, the impact on failure to use contraception and pregnancy risk are significantly greater for blacks than whites.

What can these results tell us about the potential determinants of recent trends in teens' sexual activity and contraceptive use? Recall that these trends are most clearly evident for black, non-Hispanics. For these teens, the pregnancy risk fell by nearly half, from 14.7 percent to 8.4 percent between 1991 and 1997 based on YRBS data. The main potential predictor of a decline in that level based on the above results would be labor market conditions. Between 1991 and 1997, the teen employment-to-population ratio rose from 41.9 to 43.4 . The results presented in Table 4 indicate that for this demographic group, a 1.5 percentage point increase in the teen employment-topopulation ratio would be predicted to lower the risk of becoming pregnant by 0.5 percentage points, a relatively small share of the decline. ${ }^{21}$ Other price-related factors cannot help explain much more of the decline in pregnancy risk for black teen girls. Even if the estimated effect of AIDS was stronger, AIDS cases only grew through 1993 and have fallen back since then so that the 1997 level is not much higher than that in 1991. Although welfare benefit generosity is found to be related to greater pregnancy risk, and more so for blacks, welfare benefits have become less generous through

\footnotetext{
${ }^{21}$ This calculation is based upon the increase in the teen employment-to-population ratio for all races not just black, non-Hispanics because the overall rates were used at the state level in the Probit models. But the black, non-Hispanic employment-to-population ratio rose by even more between 1991 and 1997, increasing 3.6 points from 22.6 to 26.2. Even if this larger increase was used, however, it would still explain a very small share of the decline in pregnancy risk over the period.
} 
the 1990s. On that basis, pregnancy risk should have risen. It would also be difficult to attribute any causal impact of changes in abortion rules based on the weakness of the evidence provided earlier regarding these policies. Taken as a whole, it would appear that a great deal of the decline in pregnancy risk among black, non-Hispanics that may have contributed to the dramatic decline in teen fertility among this group, cannot be explained by these factors.

\section{TEEN MOTHERHOOD AND SUBSEQUENT OUTCOMES}

The previous analysis considered the factors related to the risk of becoming pregnant, but the risk itself has not yet been defined. In particular, if a teen becomes pregnant and goes on to have a child, what cost does that impose upon her in the remainder of her life? This section will evaluate the literature examining the impact of becoming a teen mother on her labor market outcomes and receipt of public assistance.

Earlier research on this topic is well-summarized by Hofferth (1987). Results from this work identify some important life-cycle patterns in the labor market activity of teen mothers. Soon after giving birth, teen mothers face significant disadvantages compared to women who have delayed childbirth, but are similar in some other dimensions. Teen mothers have significantly lower rates of labor force participation in the years immediately following teen childbirth. This difference is eliminated or even reversed by the time the women are in their late 20 s, when those women who delayed childbearing are more likely to be caring for very young children. Little research has compared teen mothers with those who delayed childbearing until even later in life, but the available evidence suggests that teen mothers are somewhat less likely to work after their childbearing years, but that difference is small. 
Regardless of the point in the life-cycle, teen mothers earn less and have lower incomes than women who delay childbirth, even after controlling for several background characteristics. The fact that teen mothers also acquire significantly less education is strongly related to their lower earnings. Lower earnings also contributes to the higher rate of welfare receipt through the child-bearing years, although some evidence indicates that the greater relative rate of welfare receipt diminishes over time as well.

The focus of more recent research has been to introduce alternative methodologies intended to compare teen mothers with other women who are identical on all relevant characteristics. For instance, even among women who grew up in low-income, inner-city households, they may have been raised in very different family circumstances. One woman may have parents who place a heavy emphasis on education; another woman may have grown up in a household where domestic violence was prevalent. Ethnographic studies that track the lives of a relatively small number of women might be able to identify such differences. But this research can seldom be generalized to larger groups of women. Statistical analysis that relies upon large samples of individuals cannot hope to control for these "unobservable" characteristics. More recent research in this area has applied innovative methods of identifying comparison groups across which even these differences are more likely to be held constant.

Geronimus and Korenman (1992) provide one example of this type of research. They compared the outcomes (including income, employment, and welfare receipt) of sisters, one who gave birth as a teen and one who did not. Of course, sisters differ in many ways, and Geronimus and Korenman control for differences between them in many of the same types of characteristics considered in first-generation studies. Since sisters generally share a common family background, 
however, differences in outcomes between them probably cannot be attributable to these characteristics that would otherwise be unobservable in this type of study. The results of this study provide little evidence of a substantial detrimental effect of teen motherhood once these other factors are controlled for. Although the authors acknowledge that small sample sizes which lead to imprecision in their estimates limit the power of their analysis, they conclude that their results should lead one to be more cautious in attributing causality between teen motherhood and subsequent outcomes.

This research has led to a healthy exchange of papers, including replication exercises and alternative interpretations of the findings (Hoffman, et al. 1993a; Geronimus and Korenman, 1993; and Hoffman, et al. 1993b), and the controversy has led to subsequent analysis by others. For instance, Hotz, McElroy, and Sanders (1996) provide another attempt to identify a sample of women who differ only by their status as teen mothers. These authors compare women who gave birth as teenagers to teens who became pregnant, but miscarried. They report that roughly 10 percent of first teen pregnancies result in a miscarriage and that those who miscarry postpone subsequent childbearing three to four years, on average. If a miscarriage can be thought of as occurring "by chance," then it acts as a means of random assignment that separates pregnant teenagers into a pseudo-control and treatment group that can be compared using similar techniques to a controlled experiment. ${ }^{22}$ Within their quasi-experimental framework, these authors find few negative labor market consequences or greater welfare receipt brought about by a teen birth.

\footnotetext{
${ }^{22}$ Hotz, McElroy, and Sanders recognize that this assumption is not perfectly accurate and control for observable differences between the two groups in their analysis.
} 
Angrist and Evans (1996) introduce another quasi-experimental technique, using the legislative history of abortion liberalization to identify groups of women who are similar except for their status as teen mothers. They use the fact that the timing of abortion legalization in the early 1970s differed across states. In those states where abortion was legalized earlier, women, and teens in particular, may have responded by having relatively fewer children than women in states where abortion was not legalized until the 1973 Roe v. Wade Supreme Court decision. If a teen birth leads to differences in subsequent outcomes, the teenage women in these early abortion legalization states should have had different outcomes within this window compared to teenage women living in states that did not liberalize their abortion laws until 1973. Angrist and Evans show few effects, if any, from differences in abortion laws. They identify a reduction in the probability of work among adult black women who gave birth as teens, but not for whites. Moreover, even for blacks, the estimated effect is very imprecise, so it is difficult to conclusively determine whether the effect is large or small.

One last paper, by Grogger and Bronars (1993), uses a quasi-experimental design to identify relevant comparison groups. In this paper, women who have a first birth as a teen are differentiated by whether they gave birth to twins or to a single child. Viewing the occurrence of twins as a "chance" event, having twins acts as a means of random assignment where women in a pseudocontrol group have one child and women in a pseudo-treatment group have two. Comparing these groups can identify the independent effect of having an additional teen birth on the subsequent outcomes of these women. ${ }^{23}$ Results indicate that having an additional child out-of-wedlock has no

${ }^{23}$ It is important to recognize that this exercise is not completely analogous to that conducted in the previous papers discussed, which attempted to estimate the impact of becoming a teen mother (with, most likely, one child) compared to delaying childbirth. 
significant negative effect on employment, but a small positive effect on welfare receipt for white women. For black women, the impact is larger.

It is clear that differences in outcomes between teen mothers and women who delay their childbearing are not entirely attributable to the birth of the child. Based on the evidence provided by recent research, it may even be an open question whether any economic disadvantage is "caused" by teen motherhood (except, perhaps, for blacks). Based on the narrow categories of women upon which the estimates from this research are based and the general imprecision in estimated effects, however, it would be premature to definitively draw such a conclusion.

\section{SUMMARY}

The prevalence of teen sexual activity without the use of contraception is clearly a concern of the American public (despite the fact that empirical research has been unable to provide convincing evidence that the cost of a teen birth is large). This paper has documented that the level of such behavior is high by international standards and that little evidence indicates that it is declining rapidly (except, perhaps, for blacks). I have provided a discussion of alternative frameworks for thinking about this problem, with an emphasis on the contribution of economic analysis. The results of the empirical evidence provided in this paper provides some support that economic factors do affect individuals' decisions regarding sexuality and contraceptive use, although these factors cannot explain much of the recent trends. 


\section{REFERENCES}

Abma, Joyce and Freya L. Sonenstein. "Teenage Sexual Behavior and Contraceptive use: An Update." unpublished document, National Center for Health Statistics, Centers for Disease Control. April 28, 1998.

Ahituv, Avner, V. Joseph Hotz, and Tomas Philipson. "The Responsiveness of the Demand for Condoms to the Local Prevalence of AIDS." Journal of Human Resources. Vol. 31, No. 4 (Fall 1996), pp. 869-897.

Akerlof, George A., Janet L. Yellen, and Michael L. Katz. “An Analysis of Out-of-Wedlock Childbearing in the United States." Quarterly Journal of Economics. Vol. 111, No. 2 (May 1996), pp. 277-318.

Alan Guttmacher Institute. Facts in Brief: Teen Sex and Pregnancy, 1998. New York: Alan Guttmacher Institute. 1998.

Angrist, Joshua D. and William N. Evans. "Schooling and Labor Market Consequences of the 1970 State Abortion Reforms." National Bureau of Economic Research, working paper 5406, January 1996.

Argys, Laura, Susan Averett, and Daniel Rees. "Welfare Generosity, Pregnancies and Abortions Among Unmarried AFDC Recipients.” Journal of Population Economics. forthcoming.

Blank, Rebecca, Christine George, and Rebecca London, "State Abortion Rates: The Impact of Policies, Providers, Politics, Demographics, and Economic Environment," Journal of Health Economics, 15(5), October 1996, 513-553.

Brooks-Gunn, Jeanne and Frank F. Furstenberg, Jr. “Adolescent Sexual Behavior." American Psychologist. Vol. 44, No. 2 (February 1989). pp. 249-257.

Brooks-Gunn, Jeanne and Roberta Paikoff. "Sexuality and Developmental Transitions During Adolescence," pp. 190-245 in John Schulenberg, Jennifer L. Maggs, and Klaus Hurrelmann (eds.), Health Risks and Developmental Transitions during Adolescence. Cambridge, England: Cambridge University Press. 1997.

Camasso, Michael, Carol Harvey, Mark Killingsworth, and Radha Jagannathan. “New Jersey's Family Cap and Family Size Decisions: Some Findings from a 5-Year Evaluation. unpublished manuscript, Rutgers University. April 8, 1999.

Centers for Disease Control Press Office. "New CDC Report Cites Drop in Sexual Risk Behaviors Among Teens." Press Release. September 17, 1998. 
Chase-Lansdale, P. Lindsay and Jeanne Brooks-Gunn. "Correlates of Adolescent Pregnancy and Parenthood," pp. 207-236 in Celia B. Fisher and Richard M. Lerner (eds.) Applied Developmental Psychology. New York: McGraw Hill, Inc. 1994.

Coley, Rebekah Levine and P. Lindsay Chase-Lansdale. "Adolescent Pregnancy and Parenthood: Recent Evidence and Future Directions." American Psychologist, Vol. 53, No. 2 (February 1998). pp. 152-166.

Council of Economic Advisers. "The Effects of Welfare Policy and the Economic Expansion on Welfare Caseloads: An Update.” Washington, DC: Council of Economic Advisers. August 3, 1999.

Darroch, Jacqueline E., David J. Landry, and Selene Oslak. “Age Differences between Sexual Partners in the United States." Family Planning Perspectives. Vol. 31, No. 4 (July/August 1999), pp. 160-167.

Dee, Thomas S. "The Effects of Alcohol Use and Availability on Teen Childbearing." unpublished manuscript. February 1999.

Fairlie, Robert W. and Rebecca A. London. "The Effect of Incremental Benefit Levels on Births to AFDC Recipients." Journal of Policy Analysis and Management. Vol. 16, No. 4. pp. 575597.

Gallup Organization. Gallup Social and Economic Indicators - Most Important Problem. www.gallup.com/poll/indicators/indmip.asp. September 3, 1999.

Geronimus, Arline T. and Sanders Korenman. "The Socioeconomic Consequences of Teen Childbearing Reconsidered." Quarterly Journal of Economics. Vol. 107, No. 4 (November 1992). pp. 1187-1214.

Geronimus, Arline T. and Sanders Korenman. "The Socioeconomic Costs of Teenage Childbearing: Evidence and Interpretation." Demography. Vol. 30, No. 2 (May 1993). pp. 281290.

Grogger, Jeff and Stepen Bronars. "The Socioeconomic Consequences of Teenage Childbearing: Findings from a Natural Experiment." Family Planning Perspectives. Vol. 25, No. 3 (July/August 1993). pp. 156-162.

Haas-Wilson, Deborah. "The Impact of State Abortion Restrictions on Minor's Demand for Abortions." Journal of Human Resources. Vol. 31, No. 1 (Winter 1996). pp. 140-158.

Hardy, Janet B. and Laurie Schwab Zabin. Adolescent Pregnancy in an Urban Environment. Washington, DC: Urban Institute Press. 1991. 
Hayes, Cheryl (ed.). Risking the Future: Adolescent Sexuality, Pregnancy, and Childbearing. Washington, DC: National Academy Press. 1987.

Henshaw, Stanley K. Special Report: U.S. Teenage Pregnancy Statistics, With Comparative Statistics for Women Aged 20-24. New York: Alan Guttmacher Institute. June 1, 1999.

Hofferth, Sandra L. "Social and Economic Consequences of Teenage Childbearing," pp. 123144 in Cheryl D. Hayes (ed.) Risking the Future: Adolescent Sexuality, Pregnancy, and Childbearing. Washington, D.C.: National Academy Press, 1987.

Hoffman, Saul D., E. Michael Foster and Frank F. Furstenberg, Jr. "Reevaluating the Costs of Teenage Childbearing." Demography. Vol. 30, No. 1 (February 1993a). pp. 1-13.

Hoffman, Saul D., E. Michael Foster and Frank F. Furstenberg, Jr. "Reevaluating the Costs of Teenage Childbearing: Response to Geronimus and Korenman." Demography. Vol. 30, No. 2 (May 1993b). pp. 291-296.

Horvath, Ann and H. Elizabeth Peters. "Welfare Waivers and Non-Marital Childbearing." Joint Center for Poverty Research working paper \#109. September 1999.

Hotz, V. Joseph, Susan Williams McElroy, and Seth G. Sanders. "The Impacts of Teenage Childbearing on the Mothers and the Consequences of Those Impacts for Government." Kids Having Kids: Economic Costs and Social Consequences of Teen Pregnancy, ed. Rebecca A. Maynard. Washington, D.C.: The Urban Institute Press, 1996. pp. 55-94.

Kaiser Family Foundation. Is the Secret Getting Out? 1997 National Surveys of Americans and Health Care Providers on Emergency Contraception. Menlo Park, CA. 1997.

Kane, Thomas J. and Douglas Staiger. "Teen Motherhood and Abortion Access.” Quarterly Journal of Economics. Vol. 111, No. 2 (May 1996), pp. 467-506.

Levine, Phillip B., Amy B. Trainor, and David J. Zimmerman, "The Effects of Medicaid Abortion Funding Restrictions on Abortions, Pregnancies, and Births," Journal of Health Economics, 15, 1996, 555-578.

Lowenstein, George and Frank Furstenberg. “Is Teenage Sexual Behavior Rational?” Journal of Applied Social Psychology. Vol. 21, No. 12 (1991). pp. 957-986.

Lundberg, Shelly and Robert D. Plotnick. "Adolescent Premarital Childbearing: Do Economic Incentives Matter?” Journal of Labor Economics. Vol. 13, No. 2 (April 1995). pp. 177-200. 
Matthews, Stephen, David Ribar, and Mark Wilhelm, "The Effects of Economic Conditions and Access to Reproductive Health Services on State Abortion and Birthrates." Family Planning Perspectives, Vol. 29, No. 2. (March/April 1997), pp. 52-60.

Miller, Wayne J., Sirinder Wadhera, and Stanley K. Henshaw. "Repeat Abortions in Canada, 1975-1993." Family Planning Perspectives. Vol. 29, No. 1 (January/February, 1997). pp. 2024.

Moffitt, Robert. "The Effect of Welfare on Marriage and the Family," in Robert A. Moffitt (ed.) Welfare, the Family, and Reproductive Behavior. Washington, DC: National Academy Press. 1998.

Moore, Kristin A., Brent C. Miller, Dana Glei, and Donna Ruane Morrison. Adolescent Sex, Contraception, and Childbearing: A Review of Recent Research. Washington, DC: Child Trends, Inc. June 1995.

National Abortion and Reproductive Rights Action League (NARAL) Foundation. Who Decides? A State-by-State Review of Abortion and Reproductive Rights. Washington, DC: NARAL Foundation. various years.

National Center for Health Statistics Press Office. "Teen Sex Down, New Study Shows." Press Release, May 1, 1997.

O'Donoghue, Ted and Matthew Rabin. "Doing it Now or Later." American Economic Review. Vol. 89, No. 1 (March 1999). pp. 103-124.

Oettinger, Gerald S. "The Effects of Sex Education on Teen Sexual Activity and Teen Pregnancy." Journal of Political Economy. Vol. 107, No. 3 (June 1999). pp. 606-644.

O’Neill, June. “Report Concerning New Jersey’s Family Development Program.” unpublished manuscript, Baruch College. 1994.

Philipson, Tomas J. and Richard A. Posner. The AIDS Epidemic in an Economic Perspective. Cambridge, MA: Harvard University Press. 1993.

Terry, Elizabeth and Jennifer Manlove. "Trends in Sexual Activity and Contraceptive Use Among Teens." unpublished document, presented at Messengers and Methods for the New Millennium: A Round Table on Adolescents and Contraception, Child Trends. February 1999.

United Nations, Department of Economic and Social Affairs, Statistical Office. Demographic Yearbook. New York: United Nations. various years. 
U.S. Department of Health and Human Services, Office of the Assistant Secretary for Planning and Evaluation. Trends in the Well-Being of America's Children and Youth: 1998. Washington, DC: U.S. Government Printing Office. 1998.

U.S. Department of Health and Human Services, Office of Disease Prevention and Health Promotion. Healthy People 2010 - Draft. http://web.health.gov/healthypeople/default.htm. August 20, 1999b.

U.S. Department of Health and Human Services, Centers for Disease Control and Prevention. National Center for Health Statistics. Healthy People 2000 Review 1998-99. Hyattsville, MD: Department of Health and Human Services. June 1999.

U.S. Department of Health and Human Services, Public Health Service, Centers for Disease Control, National Center for Health Statistics. Report to Congress on Out-of-Wedlock

Childbearing. Hyattsville, MD: Department of Health and Human Services. September 1995.

U.S. Department of Health and Human Services, Public Health Service, Centers for Disease Control, National Center for Infectious Diseases, Division of HIV/AIDS. HIV/AIDS Surveillance Report. Various issues.

U.S. House of Representatives. The Green Book. various years.

Ventura, Stephanie J., Joyce A. Martin, Sally C. Curtin, and T.J. Mathews. "Births: Final Data for 1997." Monthly Vital Statistics Report. Vol. 27, No. 18 (April 29, 1999a).

Ventura, Stephanie J., T. J. Matthews, and Sally C. Curtin. "Declines in Teenage Birth Rates, 1991-1998: Update of National and State Trends." National Vital Statistics Reports. Vol. 47, No. 26 (October 25, 1999b).

Ventura, Stephanie J., Selma M. Taffel, William D. Mosher, Jacqueline B. Wilson, and Stanley Henshaw. "Trends in Pregnancies and Pregnancy Rates: Estimates for The United States, 198092." Monthly Vital Statistics Report. Vol. 43, No. 11(S) (May 25, 1995). 
Table 1: Sexual Activity and Contraceptive Use, by Race/Ethnicity

\begin{tabular}{|c|c|c|c|c|c|c|c|c|c|c|}
\hline & \multicolumn{3}{|c|}{$\begin{array}{c}\text { National Survey of Family Growth: } \\
\text { Ages 15-19 }\end{array}$} & \multicolumn{3}{|c|}{$\begin{array}{c}\text { National Survey of Family Growth: } \\
\text { Ages 15-17 }\end{array}$} & \multicolumn{4}{|c|}{ Youth Risk Behavior Survey } \\
\hline & 1982 & 1988 & 1995 & 1982 & 1988 & 1995 & 1991 & 1993 & 1995 & 1997 \\
\hline & \multicolumn{10}{|c|}{ SEXUAL ACTIVITY EVER } \\
\hline All & 46.9 & 52.5 & 51.1 & 32.2 & 37.7 & 38.0 & 50.8 & 50.1 & 52.1 & 47.7 \\
\hline White & 44.4 & 52.2 & 59.0 & 29.7 & 35.5 & 35.3 & 47.1 & 47.4 & 49.0 & 44.0 \\
\hline Black & 58.9 & 61.0 & 60.0 & 44.1 & 50.5 & 48.3 & 75.9 & 70.4 & 67.0 & 65.6 \\
\hline \multirow[t]{2}{*}{ Hispanic } & 49.9 & 46.9 & 56.5 & 34.4 & 34.1 & 50.4 & 43.3 & 48.3 & 53.3 & 45.7 \\
\hline & \multicolumn{10}{|c|}{ SEXUAL ACTIVITY IN PAST 3 MONTHS } \\
\hline All & 40.0 & 46.1 & 39.8 & 26.8 & 30.9 & 27.7 & 38.2 & 37.5 & 40.4 & 36.5 \\
\hline White & 37.1 & 43.1 & 39.3 & 25.2 & 27.8 & 25.9 & 35.9 & 35.2 & 38.5 & 35.1 \\
\hline Black & 53.6 & 50.8 & 45.8 & 38.8 & 39.5 & 33.9 & 55.3 & 53.2 & 50.6 & 47.3 \\
\hline \multirow[t]{2}{*}{ Hispanic } & 42.2 & 31.5 & 45.2 & 22.0 & 20.4 & 39.0 & 32.8 & 37.9 & 39.3 & 33.2 \\
\hline & \multicolumn{10}{|c|}{ NO CONTRACEPTIVE USE AT FIRST INTERCOURSE } \\
\hline All & 51.8 & 34.9 & 24.6 & 59.8 & 31.8 & 24.1 & NA & NA & NA & NA \\
\hline White & 44.1 & 30.6 & 18.9 & 51.8 & 25.7 & 19.0 & NA & NA & NA & NA \\
\hline Black & 64.1 & 46.6 & 31.7 & 68.8 & 45.0 & 28.0 & NA & NA & NA & NA \\
\hline \multirow[t]{2}{*}{ Hispanic } & 77.1 & 44.5 & 42.7 & 87.7 & 39.0 & 38.5 & NA & NA & NA & NA \\
\hline & \multicolumn{10}{|c|}{ NO CONTRACEPTIVE USE AT LAST INTERCOURSE IN PAST THREE MONTHS } \\
\hline All & NA & 22.9 & 30.6 & NA & 26.8 & 33.2 & 18.1 & 16.2 & 17.3 & 14.9 \\
\hline White & NA & 20.2 & 28.2 & NA & 22.7 & 29.6 & 13.6 & 13.7 & 13.1 & 12.9 \\
\hline Black & NA & 32.0 & 29.7 & NA & 41.4 & 27.1 & 26.9 & 22.7 & 18.3 & 17.8 \\
\hline \multirow[t]{2}{*}{ Hispanic } & NA & 32.1 & 44.4 & NA & 30.9 & 53.7 & 29.0 & 23.1 & 34.9 & 30.3 \\
\hline & \multicolumn{10}{|c|}{$\begin{array}{l}\text { "PREGNANCY RISK" } \\
\text { exually active in past three months and no contraceptive use at last intercourse) }\end{array}$} \\
\hline All & NA & 9.8 & 12.2 & NA & 7.7 & 9.2 & 6.9 & 6.0 & 6.9 & 5.4 \\
\hline White & NA & 8.7 & 11.1 & NA & 6.3 & 7.7 & 4.9 & 4.8 & 5.0 & 4.5 \\
\hline Black & NA & 16.3 & 13.6 & NA & 16.3 & 9.2 & 14.7 & 12.0 & 9.1 & 8.4 \\
\hline Hispanic & NA & 10.1 & 20.1 & NA & 6.3 & 21.0 & 9.5 & 8.7 & 13.7 & 10.0 \\
\hline
\end{tabular}

Source: Author's calculations from the 1982, 1988, and 1995 National Surveys of Family Growth and the 1991, 1993, 1995, and 1997 Youth Risk Behavior Survey.

Notes: Race/Ethnic groups are mutually exclusive. Sample weights were used in estimation so that all statistics are representative for the particular subgroup of the nation's population. Due to sample size limitations, some estimates (particularly those for birth control use for Hispanics and for the younger age category) are somewhat imprecise. 
Table 2A: Correlates of Teen Sexual Activity and Contraception for Girls

(Probit Derivatives, Standard Errors in Parentheses)

\begin{tabular}{|c|c|c|c|c|c|c|c|c|c|c|}
\hline \multirow[b]{2}{*}{ Variable } & \multicolumn{2}{|c|}{ Sexual Intercourse Ever } & \multicolumn{2}{|c|}{ Sexual in Past Three Months } & \multicolumn{2}{|c|}{$\begin{array}{l}\text { No Contraception } \\
\text { at First Intercourse }\end{array}$} & \multicolumn{2}{|c|}{ No Contraception at Last Intercourse } & \multicolumn{2}{|c|}{ "Pregnancy Risk" } \\
\hline & full sample & age $15+$ & full sample & age $15+$ & full sample & age $15+$ & full sample & age $15+$ & & \\
\hline Weighted Percentage Engaging in Activity & 37.6 & 50.9 & 35.0 & 47.7 & 32.4 & 32.5 & 35.7 & 34.6 & 12.5 & 16.5 \\
\hline \multicolumn{11}{|l|}{$\underline{\text { Student's Characteristics }}$} \\
\hline Age & $\begin{array}{c}0.079 \\
(0.017)\end{array}$ & $\begin{array}{c}0.063 \\
(0.026)\end{array}$ & $\begin{array}{c}0.076 \\
(0.016)\end{array}$ & $\begin{array}{c}0.056 \\
(0.026)\end{array}$ & $\begin{array}{c}-0.022 \\
(0.026)\end{array}$ & $\begin{array}{c}0.032 \\
(0.030)\end{array}$ & $\begin{array}{c}-0.014 \\
(0.027)\end{array}$ & $\begin{array}{c}0.003 \\
(0.031)\end{array}$ & $\begin{array}{c}0.026 \\
(0.009)\end{array}$ & $\begin{array}{c}0.019 \\
(0.014)\end{array}$ \\
\hline Black, non-Hispanic & $\begin{array}{c}0.098 \\
(0.032)\end{array}$ & $\begin{array}{c}0.066 \\
(0.043)\end{array}$ & $\begin{array}{c}0.098 \\
(0.031)\end{array}$ & $\begin{array}{c}0.044 \\
(0.043)\end{array}$ & $\begin{array}{l}-0.114 \\
(0.039)\end{array}$ & $\begin{array}{l}-0.073 \\
(0.044)\end{array}$ & $\begin{array}{l}-0.058 \\
(0.043)\end{array}$ & $\begin{array}{l}-0.018 \\
(0.050)\end{array}$ & $\begin{array}{c}0.019 \\
(0.018)\end{array}$ & $\begin{array}{c}0.016 \\
(0.025)\end{array}$ \\
\hline Hispanic & $\begin{array}{l}-0.012 \\
(0.039)\end{array}$ & $\begin{array}{l}-0.044 \\
(0.051)\end{array}$ & $\begin{array}{l}-0.021 \\
(0.038)\end{array}$ & $\begin{array}{l}-0.053 \\
(0.049)\end{array}$ & $\begin{array}{c}0.092 \\
(0.062)\end{array}$ & $\begin{array}{l}-0.019 \\
(0.063)\end{array}$ & $\begin{array}{c}0.103 \\
(0.063)\end{array}$ & $\begin{array}{c}0.092 \\
(0.067)\end{array}$ & $\begin{array}{c}0.029 \\
(0.025)\end{array}$ & $\begin{array}{c}0.027 \\
(0.031)\end{array}$ \\
\hline Grade in School & $\begin{array}{c}0.071 \\
(0.017)\end{array}$ & $\begin{array}{c}0.074 \\
(0.024)\end{array}$ & $\begin{array}{c}0.061 \\
(0.017)\end{array}$ & $\begin{array}{c}0.070 \\
(0.024)\end{array}$ & $\begin{array}{l}-0.019 \\
(0.026)\end{array}$ & $\begin{array}{l}-0.041 \\
(0.029)\end{array}$ & $\begin{array}{l}-0.010 \\
(0.027)\end{array}$ & $\begin{array}{l}-0.018 \\
(0.029)\end{array}$ & $\begin{array}{c}0.007 \\
(0.009)\end{array}$ & $\begin{array}{c}0.005 \\
(0.013)\end{array}$ \\
\hline $\begin{array}{l}\text { Picture Vocabulary Test, } \\
\text { standardized score (x10) }\end{array}$ & $\begin{array}{l}-0.001 \\
(0.009)\end{array}$ & $\begin{array}{l}-0.002 \\
(0.013)\end{array}$ & $\begin{array}{c}0.013 \\
(0.009)\end{array}$ & $\begin{array}{c}0.003 \\
(0.012)\end{array}$ & $\begin{array}{l}-0.055 \\
(0.015)\end{array}$ & $\begin{array}{l}-0.033 \\
(0.017)\end{array}$ & $\begin{array}{l}-0.052 \\
(0.015)\end{array}$ & $\begin{array}{l}-0.024 \\
(0.017)\end{array}$ & $\begin{array}{l}-0.007 \\
(0.005)\end{array}$ & $\begin{array}{l}-0.004 \\
(0.007)\end{array}$ \\
\hline GPA (if computable) & $\begin{array}{l}-0.118 \\
(0.016)\end{array}$ & $\begin{array}{l}-0.135 \\
(0.023)\end{array}$ & $\begin{array}{l}-0.105 \\
(0.015)\end{array}$ & $\begin{array}{l}-0.120 \\
(0.022)\end{array}$ & $\begin{array}{l}-0.040 \\
(0.024)\end{array}$ & $\begin{array}{c}-0.014 \\
(0.027)\end{array}$ & $\begin{array}{l}-0.037 \\
(0.025)\end{array}$ & $\begin{array}{c}-0.014 \\
(0.028)\end{array}$ & $\begin{array}{c}-0.042 \\
(0.008)\end{array}$ & $\begin{array}{l}-0.035 \\
(0.012)\end{array}$ \\
\hline Catholic & $\begin{array}{l}-0.069 \\
(0.027)\end{array}$ & $\begin{array}{c}-0.049 \\
(0.036)\end{array}$ & $\begin{array}{l}-0.060 \\
(0.026)\end{array}$ & $\begin{array}{l}-0.061 \\
(0.035)\end{array}$ & $\begin{array}{l}-0.067 \\
(0.042)\end{array}$ & $\begin{array}{l}-0.059 \\
(0.043)\end{array}$ & $\begin{array}{l}-0.071 \\
(0.044)\end{array}$ & $\begin{array}{l}-0.085 \\
(0.044)\end{array}$ & $\begin{array}{l}-0.037 \\
(0.013)\end{array}$ & $\begin{array}{l}-0.050 \\
(0.018)\end{array}$ \\
\hline No Religion Reported & $\begin{array}{l}-0.042 \\
(0.033)\end{array}$ & $\begin{array}{l}-0.046 \\
(0.055)\end{array}$ & $\begin{array}{l}-0.027 \\
(0.033)\end{array}$ & $\begin{array}{l}-0.040 \\
(0.054)\end{array}$ & $\begin{array}{c}0.120 \\
(0.055)\end{array}$ & $\begin{array}{c}0.145 \\
(0.064)\end{array}$ & $\begin{array}{c}0.127 \\
(0.056)\end{array}$ & $\begin{array}{c}0.122 \\
(0.063)\end{array}$ & $\begin{array}{c}0.031 \\
(0.023)\end{array}$ & $\begin{array}{c}0.048 \\
(0.036)\end{array}$ \\
\hline $\begin{array}{l}\text { Attends Religious Services } \\
\text { at least Once per Week }\end{array}$ & $\begin{array}{l}-0.138 \\
(0.022)\end{array}$ & $\begin{array}{l}-0.062 \\
(0.032)\end{array}$ & $\begin{array}{l}-0.130 \\
(0.022)\end{array}$ & $\begin{array}{l}-0.060 \\
(0.032)\end{array}$ & $\begin{array}{c}0.056 \\
(0.039)\end{array}$ & $\begin{array}{c}0.023 \\
(0.042)\end{array}$ & $\begin{array}{c}0.083 \\
(0.040)\end{array}$ & $\begin{array}{c}0.048 \\
(0.044)\end{array}$ & $\begin{array}{l}-0.016 \\
(0.012)\end{array}$ & $\begin{array}{c}0.005 \\
(0.019)\end{array}$ \\
\hline \multicolumn{11}{|l|}{ Family Background } \\
\hline Mother's Age (x10) & $\begin{array}{l}-0.004 \\
(0.020)\end{array}$ & $\begin{array}{c}0.013 \\
(0.028)\end{array}$ & $\begin{array}{l}-0.003 \\
(0.020)\end{array}$ & $\begin{array}{c}0.016 \\
(0.027)\end{array}$ & $\begin{array}{l}-0.006 \\
(0.030)\end{array}$ & $\begin{array}{l}-0.044 \\
(0.039)\end{array}$ & $\begin{array}{l}-0.007 \\
(0.030)\end{array}$ & $\begin{array}{l}-0.017 \\
(0.035)\end{array}$ & $\begin{array}{l}-0.002 \\
(0.012)\end{array}$ & $\begin{array}{l}-0.009 \\
(0.017)\end{array}$ \\
\hline Mother HS Graduate & $\begin{array}{c}-0.009 \\
(0.039)\end{array}$ & $\begin{array}{c}0.007 \\
(0.052)\end{array}$ & $\begin{array}{l}-0.018 \\
(0.037)\end{array}$ & $\begin{array}{l}-0.016 \\
(0.051)\end{array}$ & $\begin{array}{c}0.079 \\
(0.059)\end{array}$ & $\begin{array}{c}0.098 \\
(0.066)\end{array}$ & $\begin{array}{c}0.133 \\
(0.061)\end{array}$ & $\begin{array}{c}0.147 \\
(0.066)\end{array}$ & $\begin{array}{c}0.037 \\
(0.022)\end{array}$ & $\begin{array}{c}0.054 \\
(0.033)\end{array}$ \\
\hline Mother Attended Some College & $\begin{array}{c}0.019 \\
(0.045)\end{array}$ & $\begin{array}{c}0.082 \\
(0.059)\end{array}$ & $\begin{array}{c}0.017 \\
(0.044)\end{array}$ & $\begin{array}{c}0.079 \\
(0.058)\end{array}$ & $\begin{array}{c}0.032 \\
(0.068)\end{array}$ & $\begin{array}{c}0.020 \\
(0.074)\end{array}$ & $\begin{array}{c}0.142 \\
(0.072)\end{array}$ & $\begin{array}{c}0.130 \\
(0.078)\end{array}$ & $\begin{array}{c}0.044 \\
(0.030)\end{array}$ & $\begin{array}{c}0.068 \\
(0.043)\end{array}$ \\
\hline Mother College Graduated & $\begin{array}{l}-0.018 \\
(0.045)\end{array}$ & $\begin{array}{c}0.039 \\
(0.062)\end{array}$ & $\begin{array}{l}-0.043 \\
(0.043)\end{array}$ & $\begin{array}{c}0.017 \\
(0.061)\end{array}$ & $\begin{array}{c}0.042 \\
(0.074)\end{array}$ & $\begin{array}{c}0.068 \\
(0.082)\end{array}$ & $\begin{array}{c}0.090 \\
(0.076)\end{array}$ & $\begin{array}{c}0.126 \\
(0.084)\end{array}$ & $\begin{array}{c}0.015 \\
(0.027)\end{array}$ & $\begin{array}{c}0.057 \\
(0.043)\end{array}$ \\
\hline Mother Worked in Past Year & $\begin{array}{c}0.037 \\
(0.032)\end{array}$ & $\begin{array}{c}0.038 \\
(0.044)\end{array}$ & $\begin{array}{c}0.064 \\
(0.029)\end{array}$ & $\begin{array}{c}0.055 \\
(0.044)\end{array}$ & $\begin{array}{c}0.030 \\
(0.052)\end{array}$ & $\begin{array}{l}-0.031 \\
(0.058)\end{array}$ & $\begin{array}{c}0.044 \\
(0.053)\end{array}$ & $\begin{array}{l}-0.006 \\
(0.057)\end{array}$ & $\begin{array}{c}0.033 \\
(0.016)\end{array}$ & $\begin{array}{c}0.011 \\
(0.026)\end{array}$ \\
\hline Mother Married & $\begin{array}{l}-0.047 \\
(0.031)\end{array}$ & $\begin{array}{l}-0.078 \\
(0.043)\end{array}$ & $\begin{array}{l}-0.049 \\
(0.031)\end{array}$ & $\begin{array}{c}-0.063 \\
(0.042)\end{array}$ & $\begin{array}{c}0.003 \\
(0.045)\end{array}$ & $\begin{array}{l}-0.046 \\
(0.048)\end{array}$ & $\begin{array}{l}-0.003 \\
(0.046)\end{array}$ & $\begin{array}{l}-0.014 \\
(0.049)\end{array}$ & $\begin{array}{l}-0.011 \\
(0.018)\end{array}$ & $\begin{array}{l}-0.011 \\
(0.025)\end{array}$ \\
\hline Mother's Age at First Marriage & $\begin{array}{c}-0.003 \\
(0.021)\end{array}$ & $\begin{array}{c}-0.006 \\
(0.003)\end{array}$ & $\begin{array}{c}-0.004 \\
(0.002)\end{array}$ & $\begin{array}{c}-0.005 \\
(0.003)\end{array}$ & $\begin{array}{l}-0.002 \\
(0.003)\end{array}$ & $\begin{array}{c}-0.004 \\
(0.003)\end{array}$ & $\begin{array}{c}-0.001 \\
(0.003)\end{array}$ & $\begin{array}{c}-0.002 \\
(0.003)\end{array}$ & $\begin{array}{c}-0.001 \\
(0.001)\end{array}$ & $\begin{array}{l}-0.001 \\
(0.002)\end{array}$ \\
\hline
\end{tabular}




\begin{tabular}{|c|c|c|c|c|c|c|c|c|c|c|}
\hline Mother Receiving Public Assistance & $\begin{array}{c}0.030 \\
(0.051)\end{array}$ & $\begin{array}{c}0.048 \\
(0.067)\end{array}$ & $\begin{array}{c}0.034 \\
(0.050)\end{array}$ & $\begin{array}{c}0.089 \\
(0.065)\end{array}$ & $\begin{array}{c}0.059 \\
(0.071)\end{array}$ & $\begin{array}{l}-0.020 \\
(0.071)\end{array}$ & $\begin{array}{c}0.179 \\
(0.076)\end{array}$ & $\begin{array}{c}0.095 \\
(0.081)\end{array}$ & $\begin{array}{c}0.069 \\
(0.036)\end{array}$ & $\begin{array}{c}0.083 \\
(0.051)\end{array}$ \\
\hline $\mathrm{HH}$ Income less than $\$ 10,000$ & $\begin{array}{c}0.033 \\
(0.057)\end{array}$ & $\begin{array}{c}0.027 \\
(0.078)\end{array}$ & $\begin{array}{c}0.044 \\
(0.056)\end{array}$ & $\begin{array}{c}0.004 \\
(0.077)\end{array}$ & $\begin{array}{l}-0.028 \\
(0.074)\end{array}$ & $\begin{array}{l}-0.077 \\
(0.073)\end{array}$ & $\begin{array}{l}-0.087 \\
(0.073)\end{array}$ & $\begin{array}{l}-0.143 \\
(0.071)\end{array}$ & $\begin{array}{l}-0.009 \\
(0.027)\end{array}$ & $\begin{array}{l}-0.061 \\
(0.031)\end{array}$ \\
\hline $\begin{array}{l}\text { HH Income between } \\
\$ 10,000 \text { and } \$ 30,000\end{array}$ & $\begin{array}{l}-0.031 \\
(0.035)\end{array}$ & $\begin{array}{l}-0.081 \\
(0.049)\end{array}$ & $\begin{array}{l}-0.023 \\
(0.035)\end{array}$ & $\begin{array}{l}-0.062 \\
(0.048)\end{array}$ & $\begin{array}{c}0.033 \\
(0.055)\end{array}$ & $\begin{array}{l}-0.025 \\
(0.058)\end{array}$ & $\begin{array}{l}-0.017 \\
(0.056)\end{array}$ & $\begin{array}{c}0.015 \\
(0.062)\end{array}$ & $\begin{array}{l}-0.012 \\
(0.019)\end{array}$ & $\begin{array}{l}-0.011 \\
(0.027)\end{array}$ \\
\hline $\begin{array}{l}\text { HH Income between } \\
\$ 50,000 \text { and } \$ 100,000\end{array}$ & $\begin{array}{l}-0.046 \\
(0.032)\end{array}$ & $\begin{array}{l}-0.048 \\
(0.045)\end{array}$ & $\begin{array}{l}-0.028 \\
(0.031)\end{array}$ & $\begin{array}{l}-0.031 \\
(0.044)\end{array}$ & $\begin{array}{l}-0.040 \\
(0.052)\end{array}$ & $\begin{array}{l}-0.059 \\
(0.052)\end{array}$ & $\begin{array}{l}-0.074 \\
(0.050)\end{array}$ & $\begin{array}{l}-0.086 \\
(0.053)\end{array}$ & $\begin{array}{l}-0.031 \\
(0.016)\end{array}$ & $\begin{array}{l}-0.040 \\
(0.023)\end{array}$ \\
\hline HH Income greater than $\$ 100,000$ & $\begin{array}{l}-0.071 \\
(0.049)\end{array}$ & $\begin{array}{l}-0.105 \\
(0.072)\end{array}$ & $\begin{array}{l}-0.057 \\
(0.049)\end{array}$ & $\begin{array}{l}-0.107 \\
(0.069)\end{array}$ & $\begin{array}{l}-0.077 \\
(0.086)\end{array}$ & $\begin{array}{l}-0.105 \\
(0.080)\end{array}$ & $\begin{array}{l}-0.166 \\
(0.077)\end{array}$ & $\begin{array}{l}-0.165 \\
(0.078)\end{array}$ & $\begin{array}{l}-0.055 \\
(0.020)\end{array}$ & $\begin{array}{l}-0.085 \\
(0.023)\end{array}$ \\
\hline \multicolumn{11}{|l|}{$\begin{array}{l}\text { Own Attitudes/ } \\
\text { Expectations/Knowledge }\end{array}$} \\
\hline $\begin{array}{l}\text { Friends Respect you More if } \\
\text { You Have Sexual Intercourse }\end{array}$ & & $\begin{array}{l}-0.012 \\
(0.074)\end{array}$ & & $\begin{array}{c}0.007 \\
(0.072)\end{array}$ & & $\begin{array}{c}0.106 \\
(0.070)\end{array}$ & & $\begin{array}{l}-0.035 \\
(0.091)\end{array}$ & & $\begin{array}{l}-0.024 \\
(0.039)\end{array}$ \\
\hline $\begin{array}{l}\text { Partner Loses Respect for You if } \\
\text { You Have Sexual Intercourse }\end{array}$ & & $\begin{array}{l}-0.139 \\
(0.038)\end{array}$ & & $\begin{array}{l}-0.159 \\
(0.037)\end{array}$ & & $\begin{array}{c}0.082 \\
(0.060)\end{array}$ & & $\begin{array}{c}0.087 \\
(0.063)\end{array}$ & & $\begin{array}{l}-0.021 \\
(0.022)\end{array}$ \\
\hline $\begin{array}{l}\text { Getting Pregnant Would be } \\
\text { One of the Worst Things }\end{array}$ & & $\begin{array}{l}-0.195 \\
(0.039)\end{array}$ & & $\begin{array}{l}-0.170 \\
(0.040)\end{array}$ & & $\begin{array}{l}-0.032 \\
(0.044)\end{array}$ & & $\begin{array}{l}-0.208 \\
(0.047)\end{array}$ & & $\begin{array}{l}-0.147 \\
(0.031)\end{array}$ \\
\hline Likely to go to College & & $\begin{array}{l}-0.064 \\
(0.041)\end{array}$ & & $\begin{array}{l}-0.060 \\
(0.040)\end{array}$ & & $\begin{array}{l}-0.062 \\
(0.047)\end{array}$ & & $\begin{array}{l}-0.042 \\
(0.048)\end{array}$ & & $\begin{array}{l}-0.033 \\
(0.025)\end{array}$ \\
\hline $\begin{array}{l}\text { Percent Correct on } \\
\text { Knowledge Quiz }\end{array}$ & & $\begin{array}{c}0.004 \\
(0.001)\end{array}$ & & $\begin{array}{c}0.005 \\
(0.001)\end{array}$ & & $\begin{array}{l}-0.001 \\
(0.001)\end{array}$ & & $\begin{array}{l}-0.003 \\
(0.001)\end{array}$ & & $\begin{array}{l}0.0001 \\
(0.001)\end{array}$ \\
\hline \multicolumn{11}{|l|}{ Parents' Attitudes } \\
\hline $\begin{array}{l}\text { Mother Disapproves of } \\
\text { Having Sex at this Time }\end{array}$ & & $\begin{array}{l}-0.227 \\
(0.039)\end{array}$ & & $\begin{array}{l}-0.201 \\
(0.039)\end{array}$ & & $\begin{array}{l}-0.020 \\
(0.040)\end{array}$ & & $\begin{array}{l}-0.084 \\
(0.041)\end{array}$ & & $\begin{array}{l}-0.080 \\
(0.026)\end{array}$ \\
\hline $\begin{array}{l}\text { Mother Disapproves of } \\
\text { Birth Control Use at this Time }\end{array}$ & & $\begin{array}{l}-0.202 \\
(0.031)\end{array}$ & & $\begin{array}{l}-0.186 \\
(0.031)\end{array}$ & & $\begin{array}{c}0.150 \\
(0.050)\end{array}$ & & $\begin{array}{c}0.091 \\
(0.050)\end{array}$ & & $\begin{array}{l}-0.025 \\
(0.019)\end{array}$ \\
\hline \multicolumn{11}{|l|}{$\underline{\text { Risk Perceptions }}$} \\
\hline $\begin{array}{l}\text { Little or No Probability of } \\
\text { Pregnancy in Single Incident }\end{array}$ & & $\begin{array}{l}-0.003 \\
(0.042)\end{array}$ & & $\begin{array}{l}-0.009 \\
(0.041)\end{array}$ & & $\begin{array}{c}0.177 \\
(0.055)\end{array}$ & & $\begin{array}{c}0.125 \\
(0.056)\end{array}$ & & $\begin{array}{c}0.049 \\
(0.028)\end{array}$ \\
\hline $\begin{array}{l}\text { Little or No Probability of } \\
\text { Pregnancy over Entire Month }\end{array}$ & & $\begin{array}{c}0.132 \\
(0.041)\end{array}$ & & $\begin{array}{c}0.102 \\
(0.042)\end{array}$ & & $\begin{array}{c}0.029 \\
(0.048)\end{array}$ & & $\begin{array}{c}0.007 \\
(0.050)\end{array}$ & & $\begin{array}{c}0.028 \\
(0.027)\end{array}$ \\
\hline SAMPLE SIZE & 3,023 & 1,830 & 3,050 & 1,836 & 1,107 & 874 & 1,049 & 831 & 3,050 & 1,836 \\
\hline
\end{tabular}

Source Anthor's calculations from Wave I of the National Longitudinal Survey of Adolescent Health'

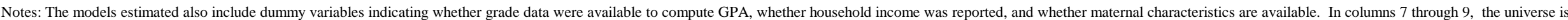
restricted to those women who have ever engaged in sexual intercourse. In Columns 10-12, the universe is restricted to those women who have had intercourse in the past three months. 
Table 2B: Correlates of Teen Sexual Activity and Contraception for Boys

(Probit Derivatives, Standard Errors in Parentheses)

\begin{tabular}{|c|c|c|c|c|c|c|c|c|c|c|}
\hline \multirow[b]{2}{*}{ Variable } & \multicolumn{2}{|c|}{ Sexual Intercourse Ever } & \multicolumn{2}{|c|}{ Sexual in Past Three Months } & \multicolumn{2}{|c|}{$\begin{array}{l}\text { No Contraception } \\
\text { at First Intercourse }\end{array}$} & \multicolumn{2}{|c|}{ No Contraception at Last Intercourse } & \multicolumn{2}{|c|}{ Partner's "Pregnancy Risk" } \\
\hline & full sample & age $15+$ & full sample & age $15+$ & full sample & age $15+$ & full sample & age $15+$ & full sample & age $15+$ \\
\hline Weighted Percentage Engaging in Activity & 38.9 & 50.3 & 34.0 & 44.7 & 34.0 & 33.0 & 30.2 & 30.3 & 10.3 & 13.5 \\
\hline \multicolumn{11}{|l|}{$\underline{\text { Student's Characteristics }}$} \\
\hline Age & $\begin{array}{c}0.083 \\
(0.168)\end{array}$ & $\begin{array}{c}0.067 \\
(0.025)\end{array}$ & $\begin{array}{c}0.080 \\
(0.015)\end{array}$ & $\begin{array}{c}0.068 \\
(0.024)\end{array}$ & $\begin{array}{c}-0.022 \\
(0.023)\end{array}$ & $\begin{array}{c}0.002 \\
(0.027)\end{array}$ & $\begin{array}{c}0.022 \\
(0.022)\end{array}$ & $\begin{array}{c}0.010 \\
(0.029)\end{array}$ & $\begin{array}{c}0.028 \\
(0.008)\end{array}$ & $\begin{array}{c}0.018 \\
(0.014)\end{array}$ \\
\hline Black, non-Hispanic & $\begin{array}{c}0.257 \\
(0.033)\end{array}$ & $\begin{array}{c}0.169 \\
(0.042)\end{array}$ & $\begin{array}{c}0.218 \\
(0.032)\end{array}$ & $\begin{array}{c}0.116 \\
(0.042)\end{array}$ & $\begin{array}{c}0.015 \\
(0.042)\end{array}$ & $\begin{array}{c}0.031 \\
(0.048)\end{array}$ & $\begin{array}{l}-0.036 \\
(0.042)\end{array}$ & $\begin{array}{l}-0.019 \\
(0.050)\end{array}$ & $\begin{array}{c}0.034 \\
(0.017)\end{array}$ & $\begin{array}{c}0.015 \\
(0.025)\end{array}$ \\
\hline Hispanic & $\begin{array}{c}0.043 \\
(0.040)\end{array}$ & $\begin{array}{l}-0.006 \\
(0.052)\end{array}$ & $\begin{array}{c}0.071 \\
(0.038)\end{array}$ & $\begin{array}{c}0.046 \\
(0.050)\end{array}$ & $\begin{array}{c}0.135 \\
(0.058)\end{array}$ & $\begin{array}{c}0.037 \\
(0.064)\end{array}$ & $\begin{array}{c}0.034 \\
(0.057)\end{array}$ & $\begin{array}{l}-0.007 \\
(0.062)\end{array}$ & $\begin{array}{c}0.027 \\
(0.022)\end{array}$ & $\begin{array}{c}0.005 \\
(0.028)\end{array}$ \\
\hline Grade in School & $\begin{array}{c}0.033 \\
(0.017)\end{array}$ & $\begin{array}{l}-0.002 \\
(0.022)\end{array}$ & $\begin{array}{c}0.028 \\
(0.016)\end{array}$ & $\begin{array}{l}-0.004 \\
(0.022)\end{array}$ & $\begin{array}{c}0.013 \\
(0.023)\end{array}$ & $\begin{array}{c}0.008 \\
(0.025)\end{array}$ & $\begin{array}{l}-0.016 \\
(0.023)\end{array}$ & $\begin{array}{c}0.005 \\
(0.026)\end{array}$ & $\begin{array}{l}-0.000 \\
(0.008)\end{array}$ & $\begin{array}{c}0.000 \\
(0.012)\end{array}$ \\
\hline $\begin{array}{l}\text { Picture Vocabulary Test, } \\
\text { standardized score (x10) }\end{array}$ & $\begin{array}{l}-0.017 \\
(0.009)\end{array}$ & $\begin{array}{l}-0.016 \\
(0.013)\end{array}$ & $\begin{array}{l}-0.003 \\
(0.008)\end{array}$ & $\begin{array}{l}-0.006 \\
(0.013)\end{array}$ & $\begin{array}{l}-0.002 \\
(0.014)\end{array}$ & $\begin{array}{l}-0.000 \\
(0.016)\end{array}$ & $\begin{array}{l}-0.001 \\
(0.001)\end{array}$ & $\begin{array}{l}-0.002 \\
(0.002)\end{array}$ & $\begin{array}{l}-0.004 \\
(0.004)\end{array}$ & $\begin{array}{l}-0.007 \\
(0.007)\end{array}$ \\
\hline GPA (if computable) & $\begin{array}{l}-0.108 \\
(0.015)\end{array}$ & $\begin{array}{l}-0.090 \\
(0.021)\end{array}$ & $\begin{array}{l}-0.101 \\
(0.014)\end{array}$ & $\begin{array}{l}-0.088 \\
(0.021)\end{array}$ & $\begin{array}{l}-0.009 \\
(0.023)\end{array}$ & $\begin{array}{c}0.010 \\
(0.026)\end{array}$ & $\begin{array}{l}-0.037 \\
(0.023)\end{array}$ & $\begin{array}{l}-0.029 \\
(0.027)\end{array}$ & $\begin{array}{l}-0.036 \\
(0.008)\end{array}$ & $\begin{array}{c}-0.033 \\
(0.012)\end{array}$ \\
\hline Catholic & $\begin{array}{l}-0.032 \\
(0.029)\end{array}$ & $\begin{array}{l}-0.050 \\
(0.037)\end{array}$ & $\begin{array}{l}-0.030 \\
(0.027)\end{array}$ & $\begin{array}{l}-0.063 \\
(0.036)\end{array}$ & $\begin{array}{l}-0.008 \\
(0.045)\end{array}$ & $\begin{array}{c}0.041 \\
(0.052)\end{array}$ & $\begin{array}{c}0.012 \\
(0.047)\end{array}$ & $\begin{array}{l}-0.007 \\
(0.051)\end{array}$ & $\begin{array}{l}-0.005 \\
(0.014)\end{array}$ & $\begin{array}{l}-0.020 \\
(0.020)\end{array}$ \\
\hline No Religion Reported & $\begin{array}{c}0.062 \\
(0.037)\end{array}$ & $\begin{array}{c}0.020 \\
(0.051)\end{array}$ & $\begin{array}{c}0.080 \\
(0.035)\end{array}$ & $\begin{array}{c}0.048 \\
(0.049)\end{array}$ & $\begin{array}{c}0.071 \\
(0.050)\end{array}$ & $\begin{array}{c}0.070 \\
(0.059)\end{array}$ & $\begin{array}{c}0.064 \\
(0.052)\end{array}$ & $\begin{array}{c}0.037 \\
(0.059)\end{array}$ & $\begin{array}{c}0.040 \\
(0.022)\end{array}$ & $\begin{array}{c}0.021 \\
(0.029)\end{array}$ \\
\hline $\begin{array}{l}\text { Attends Religious Services } \\
\text { at least Once per Week }\end{array}$ & $\begin{array}{l}-0.099 \\
(0.024)\end{array}$ & $\begin{array}{l}-0.050 \\
(0.034)\end{array}$ & $\begin{array}{l}-0.075 \\
(0.022)\end{array}$ & $\begin{array}{l}-0.028 \\
(0.033)\end{array}$ & $\begin{array}{c}0.021 \\
(0.039)\end{array}$ & $\begin{array}{c}0.071 \\
(0.046)\end{array}$ & $\begin{array}{c}0.024 \\
(0.041)\end{array}$ & $\begin{array}{c}0.040 \\
(0.047)\end{array}$ & $\begin{array}{l}-0.014 \\
(0.012)\end{array}$ & $\begin{array}{c}0.005 \\
(0.020)\end{array}$ \\
\hline \multicolumn{11}{|l|}{ Family Background } \\
\hline Mother's Age (x10) & $\begin{array}{c}0.005 \\
(0.021)\end{array}$ & $\begin{array}{c}0.018 \\
(0.028)\end{array}$ & $\begin{array}{c}0.000 \\
(0.020)\end{array}$ & $\begin{array}{c}0.005 \\
(0.028)\end{array}$ & $\begin{array}{c}0.009 \\
(0.029)\end{array}$ & $\begin{array}{l}-0.023 \\
(0.031)\end{array}$ & $\begin{array}{l}-0.011 \\
(0.031)\end{array}$ & $\begin{array}{l}-0.034 \\
(0.034)\end{array}$ & $\begin{array}{l}-0.001 \\
(0.010)\end{array}$ & $\begin{array}{l}-0.009 \\
(0.016)\end{array}$ \\
\hline Mother HS Graduate & $\begin{array}{c}-0.013 \\
(0.039)\end{array}$ & $\begin{array}{c}-0.035 \\
(0.052)\end{array}$ & $\begin{array}{c}0.028 \\
(0.037)\end{array}$ & $\begin{array}{l}-0.000 \\
(0.051)\end{array}$ & $\begin{array}{c}0.036 \\
(0.055)\end{array}$ & $\begin{array}{c}0.059 \\
(0.062)\end{array}$ & $\begin{array}{c}0.026 \\
(0.058)\end{array}$ & $\begin{array}{c}0.027 \\
(0.062)\end{array}$ & $\begin{array}{c}0.014 \\
(0.021)\end{array}$ & $\begin{array}{c}0.004 \\
(0.029)\end{array}$ \\
\hline Mother Attended Some College & $\begin{array}{l}-0.031 \\
(0.043)\end{array}$ & $\begin{array}{c}0.012 \\
(0.059)\end{array}$ & $\begin{array}{c}0.015 \\
(0.042)\end{array}$ & $\begin{array}{c}0.050 \\
(0.058)\end{array}$ & $\begin{array}{c}0.038 \\
(0.065)\end{array}$ & $\begin{array}{c}0.096 \\
(0.074)\end{array}$ & $\begin{array}{l}-0.028 \\
(0.065)\end{array}$ & $\begin{array}{c}0.016 \\
(0.074)\end{array}$ & $\begin{array}{l}-0.006 \\
(0.023)\end{array}$ & $\begin{array}{c}0.013 \\
(0.035)\end{array}$ \\
\hline Mother College Graduated & $\begin{array}{l}-0.093 \\
(0.045)\end{array}$ & $\begin{array}{l}-0.036 \\
(0.062)\end{array}$ & $\begin{array}{l}-0.052 \\
(0.043)\end{array}$ & $\begin{array}{l}-0.009 \\
(0.060)\end{array}$ & $\begin{array}{l}-0.040 \\
(0.070)\end{array}$ & $\begin{array}{c}0.015 \\
(0.081)\end{array}$ & $\begin{array}{c}0.071 \\
(0.080)\end{array}$ & $\begin{array}{c}0.102 \\
(0.087)\end{array}$ & $\begin{array}{l}-0.006 \\
(0.023)\end{array}$ & $\begin{array}{c}0.040 \\
(0.041)\end{array}$ \\
\hline Mother Worked in Past Year & $\begin{array}{c}0.012 \\
(0.032)\end{array}$ & $\begin{array}{c}0.015 \\
(0.045)\end{array}$ & $\begin{array}{c}0.006 \\
(0.029)\end{array}$ & $\begin{array}{c}0.003 \\
(0.043)\end{array}$ & $\begin{array}{c}0.015 \\
(0.049)\end{array}$ & $\begin{array}{c}0.039 \\
(0.054)\end{array}$ & $\begin{array}{l}-0.024 \\
(0.052)\end{array}$ & $\begin{array}{l}-0.043 \\
(0.058)\end{array}$ & $\begin{array}{l}-0.007 \\
(0.016)\end{array}$ & $\begin{array}{l}-0.016 \\
(0.024)\end{array}$ \\
\hline Mother Married & $\begin{array}{l}-0.113 \\
(0.033)\end{array}$ & $\begin{array}{l}-0.047 \\
(0.044)\end{array}$ & $\begin{array}{l}-0.093 \\
(0.031)\end{array}$ & $\begin{array}{l}-0.030 \\
(0.043)\end{array}$ & $\begin{array}{c}0.002 \\
(0.045)\end{array}$ & $\begin{array}{l}-0.019 \\
(0.050)\end{array}$ & $\begin{array}{l}-0.017 \\
(0.046)\end{array}$ & $\begin{array}{l}-0.030 \\
(0.051)\end{array}$ & $\begin{array}{l}-0.028 \\
(0.017)\end{array}$ & $\begin{array}{l}-0.021 \\
(0.024)\end{array}$ \\
\hline Mother's Age at First Marriage & $\begin{array}{l}-0.002 \\
(0.002)\end{array}$ & $\begin{array}{c}-0.011 \\
(0.004)\end{array}$ & $\begin{array}{l}-0.004 \\
(0.002)\end{array}$ & $\begin{array}{c}-0.010 \\
(0.003)\end{array}$ & $\begin{array}{c}-0.006 \\
(0.003)\end{array}$ & $\begin{array}{l}-0.008 \\
(0.004)\end{array}$ & $\begin{array}{c}-0.004 \\
(0.003)\end{array}$ & $\begin{array}{l}-0.007 \\
(0.036)\end{array}$ & $\begin{array}{c}-0.002 \\
(0.001)\end{array}$ & $\begin{array}{l}-0.005 \\
(0.002)\end{array}$ \\
\hline
\end{tabular}




\begin{tabular}{|c|c|c|c|c|c|c|c|c|c|c|}
\hline Mother Receiving Public Assistance & $\begin{array}{c}0.019 \\
(0.052)\end{array}$ & $\begin{array}{l}-0.017 \\
(0.076)\end{array}$ & $\begin{array}{c}0.002 \\
(0.047)\end{array}$ & $\begin{array}{l}-0.010 \\
(0.071)\end{array}$ & $\begin{array}{l}-0.070 \\
(0.057)\end{array}$ & $\begin{array}{l}-0.097 \\
(0.061)\end{array}$ & $\begin{array}{c}0.006 \\
(0.067)\end{array}$ & $\begin{array}{l}-0.025 \\
(0.076)\end{array}$ & $\begin{array}{c}0.000 \\
(0.023)\end{array}$ & $\begin{array}{l}-0.015 \\
(0.033)\end{array}$ \\
\hline HH Income less than $\$ 10,000$ & $\begin{array}{l}-0.043 \\
(0.053)\end{array}$ & $\begin{array}{l}-0.075 \\
(0.078)\end{array}$ & $\begin{array}{l}-0.069 \\
(0.048)\end{array}$ & $\begin{array}{l}-0.124 \\
(0.069)\end{array}$ & $\begin{array}{c}0.097 \\
(0.085)\end{array}$ & $\begin{array}{c}0.125 \\
(0.107)\end{array}$ & $\begin{array}{l}-0.037 \\
(0.079)\end{array}$ & $\begin{array}{l}-0.067 \\
(0.091)\end{array}$ & $\begin{array}{l}-0.023 \\
(0.022)\end{array}$ & $\begin{array}{l}-0.048 \\
(0.030)\end{array}$ \\
\hline $\begin{array}{l}\text { HH Income between } \\
\$ 10,000 \text { and } \$ 30,000\end{array}$ & $\begin{array}{c}0.010 \\
(0.035)\end{array}$ & $\begin{array}{l}-0.022 \\
(0.047)\end{array}$ & $\begin{array}{c}0.016 \\
(0.033)\end{array}$ & $\begin{array}{c}0.022 \\
(0.047)\end{array}$ & $\begin{array}{c}0.008 \\
(0.052)\end{array}$ & $\begin{array}{l}-0.020 \\
(0.057)\end{array}$ & $\begin{array}{l}-0.020 \\
(0.051)\end{array}$ & $\begin{array}{l}-0.104 \\
(0.053)\end{array}$ & $\begin{array}{c}0.002 \\
(0.018)\end{array}$ & $\begin{array}{l}-0.036 \\
(0.022)\end{array}$ \\
\hline $\begin{array}{l}\text { HH Income between } \\
\$ 50,000 \text { and } \$ 100,000\end{array}$ & $\begin{array}{l}-0.012 \\
(0.034)\end{array}$ & $\begin{array}{l}-0.010 \\
(0.044)\end{array}$ & $\begin{array}{l}-0.007 \\
(0.032)\end{array}$ & $\begin{array}{l}-0.008 \\
(0.043)\end{array}$ & $\begin{array}{c}0.010 \\
(0.057)\end{array}$ & $\begin{array}{l}-0.009 \\
(0.060)\end{array}$ & $\begin{array}{l}-0.060 \\
(0.053)\end{array}$ & $\begin{array}{l}-0.123 \\
(0.052)\end{array}$ & $\begin{array}{l}-0.016 \\
(0.016)\end{array}$ & $\begin{array}{l}-0.051 \\
(0.021)\end{array}$ \\
\hline $\mathrm{HH}$ Income greater than $\$ 100,000$ & $\begin{array}{l}-0.090 \\
(0.054)\end{array}$ & $\begin{array}{l}-0.170 \\
(0.064)\end{array}$ & $\begin{array}{l}-0.058 \\
(0.051)\end{array}$ & $\begin{array}{l}-0.152 \\
(0.060)\end{array}$ & $\begin{array}{l}-0.057 \\
(0.095)\end{array}$ & $\begin{array}{l}-0.026 \\
(0.108)\end{array}$ & $\begin{array}{l}-0.099 \\
(0.085)\end{array}$ & $\begin{array}{l}-0.109 \\
(0.092)\end{array}$ & $\begin{array}{l}-0.044 \\
(0.019)\end{array}$ & $\begin{array}{l}-0.073 \\
(0.024)\end{array}$ \\
\hline \multicolumn{11}{|l|}{$\begin{array}{l}\text { Own Attitudes/ } \\
\text { Expectations/Knowledge }\end{array}$} \\
\hline $\begin{array}{l}\text { Friends Respect you More if } \\
\text { You Have Sexual Intercourse }\end{array}$ & & $\begin{array}{c}0.101 \\
(0.038)\end{array}$ & & $\begin{array}{c}0.107 \\
(0.038)\end{array}$ & & $\begin{array}{c}0.101 \\
(0.045)\end{array}$ & & $\begin{array}{c}0.099 \\
(0.047)\end{array}$ & & $\begin{array}{c}0.072 \\
(0.026)\end{array}$ \\
\hline $\begin{array}{l}\text { Partner Loses Respect for You if } \\
\text { You Have Sexual Intercourse }\end{array}$ & & $\begin{array}{l}-0.146 \\
(0.043)\end{array}$ & & $\begin{array}{l}-0.137 \\
(0.042)\end{array}$ & & $\begin{array}{c}0.115 \\
(0.074)\end{array}$ & & $\begin{array}{l}-0.009 \\
(0.075)\end{array}$ & & $\begin{array}{l}-0.029 \\
(0.024)\end{array}$ \\
\hline $\begin{array}{l}\text { Getting Someone Pregnant Would be } \\
\text { One of the Worst Things }\end{array}$ & & $\begin{array}{l}-0.111 \\
(0.045)\end{array}$ & & $\begin{array}{l}-0.144 \\
(0.044)\end{array}$ & & $\begin{array}{c}-0.121 \\
90.051)\end{array}$ & & $\begin{array}{l}-0.115 \\
(0.052)\end{array}$ & & $\begin{array}{l}-0.087 \\
(0.031)\end{array}$ \\
\hline Likely to go to College & & $\begin{array}{l}-0.122 \\
(0.036)\end{array}$ & & $\begin{array}{l}-0.068 \\
(0.035)\end{array}$ & & $\begin{array}{l}-0.076 \\
(0.041)\end{array}$ & & $\begin{array}{l}-0.050 \\
(0.043)\end{array}$ & & $\begin{array}{l}-0.039 \\
(0.021)\end{array}$ \\
\hline $\begin{array}{l}\text { Percent Correct on } \\
\text { Knowledge Quiz }\end{array}$ & & $\begin{array}{c}0.003 \\
(0.001)\end{array}$ & & $\begin{array}{c}0.003 \\
(0.001)\end{array}$ & & $\begin{array}{l}-0.001 \\
(0.001)\end{array}$ & & $\begin{array}{c}0.000 \\
(0.001)\end{array}$ & & $\begin{array}{c}0.001 \\
(0.0004)\end{array}$ \\
\hline \multicolumn{11}{|l|}{ Parents' Attitudes } \\
\hline $\begin{array}{l}\text { Mother Disapproves of } \\
\text { Having Sex at this Time }\end{array}$ & & $\begin{array}{l}-0.199 \\
(0.034)\end{array}$ & & $\begin{array}{l}-0.171 \\
(0.035)\end{array}$ & & $\begin{array}{c}0.062 \\
(0.040)\end{array}$ & & $\begin{array}{c}0.012 \\
90.042)\end{array}$ & & $\begin{array}{l}-0.029 \\
(0.022)\end{array}$ \\
\hline $\begin{array}{l}\text { Mother Disapproves of } \\
\text { Birth Control Use at this Time }\end{array}$ & & $\begin{array}{l}-0.091 \\
(0.036)\end{array}$ & & $\begin{array}{l}-0.098 \\
(0.035)\end{array}$ & & $\begin{array}{c}0.065 \\
(0.055)\end{array}$ & & $\begin{array}{c}0.075 \\
(0.056)\end{array}$ & & $\begin{array}{l}-0.007 \\
(0.022)\end{array}$ \\
\hline$\underline{\text { Risk Perceptions }}$ & & & & & & & & $\begin{array}{c}0.070 \\
(0.047)\end{array}$ & & $\begin{array}{c}0.042 \\
(0.023)\end{array}$ \\
\hline $\begin{array}{l}\text { Little or No Probability of } \\
\text { Pregnancy in Single Incident }\end{array}$ & & $\begin{array}{c}0.024 \\
(0.037)\end{array}$ & & $\begin{array}{c}0.045 \\
(0.036)\end{array}$ & & $\begin{array}{c}0.113 \\
(0.045)\end{array}$ & & $\begin{array}{c}0.050 \\
(0.045)\end{array}$ & & $\begin{array}{c}0.036 \\
(0.021)\end{array}$ \\
\hline $\begin{array}{l}\text { Little or No Probability of } \\
\text { Pregnancy over Entire Month }\end{array}$ & & $\begin{array}{c}0.054 \\
(0.035)\end{array}$ & & $\begin{array}{c}0.052 \\
(0.034)\end{array}$ & & $\begin{array}{c}0.032 \\
(0.042)\end{array}$ & & & & \\
\hline SAMPLE SIZE & 2,795 & 1,734 & 2,832 & 1,747 & 1,135 & 866 & 1,021 & 792 & 2,831 & 1,746 \\
\hline
\end{tabular}

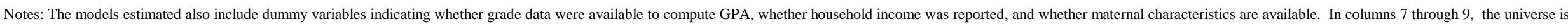
restricted to those women who have ever engaged in sexual intercourse. In Columns 10-12, the universe is restricted to those women who have had intercourse in the past three months. 
Table 3: The Relationship between Geographic Factors and Teen Sexual Activity, Contraception, and Pregnancy

(Probit Derivatives, Standard Errors in Parentheses)

\begin{tabular}{|c|c|c|c|c|c|c|c|c|}
\hline \multirow[b]{2}{*}{ Variable } & \multicolumn{2}{|c|}{ Sexual Intercourse Ever } & \multicolumn{2}{|c|}{$\begin{array}{l}\text { Sexual Intercourse in } \\
\text { Past Three Months }\end{array}$} & \multicolumn{2}{|c|}{$\begin{array}{l}\text { No Contraception Used at Last } \\
\text { Intercourse in Past } 3 \text { Months }\end{array}$} & \multicolumn{2}{|c|}{ "Pregnancy Risk" } \\
\hline & $\begin{array}{l}\text { Girls } \\
(1)\end{array}$ & $\begin{array}{l}\text { Boys } \\
\text { (2) }\end{array}$ & $\begin{array}{l}\text { Girls } \\
(3)\end{array}$ & $\begin{array}{c}\text { Boys } \\
\text { (4) }\end{array}$ & $\begin{array}{l}\text { Girls } \\
(5)\end{array}$ & $\begin{array}{c}\text { Boys } \\
(6)\end{array}$ & $\begin{array}{l}\text { Girls } \\
(7)\end{array}$ & $\begin{array}{c}\text { Boys } \\
(8)\end{array}$ \\
\hline Weighted Percentage Engaging in Activity & 49.6 & 53.0 & 37.6 & 35.2 & 16.5 & 14.7 & 6.2 & 5.2 \\
\hline \multicolumn{9}{|l|}{ Student's Characteristics } \\
\hline Age & $\begin{array}{c}0.100 \\
(0.008)\end{array}$ & $\begin{array}{c}0.105 \\
(0.009)\end{array}$ & $\begin{array}{c}0.086 \\
(0.008)\end{array}$ & $\begin{array}{c}0.081 \\
(0.008)\end{array}$ & $\begin{array}{c}0.028 \\
(0.009)\end{array}$ & $\begin{array}{c}0.006 \\
(0.009)\end{array}$ & $\begin{array}{c}0.023 \\
(0.003)\end{array}$ & $\begin{array}{c}0.013 \\
(0.003)\end{array}$ \\
\hline Black, non-Hispanic & $\begin{array}{c}0.213 \\
(0.018)\end{array}$ & $\begin{array}{c}0.365 \\
(0.012)\end{array}$ & $\begin{array}{c}0.138 \\
(0.016)\end{array}$ & $\begin{array}{c}0.307 \\
(0.018)\end{array}$ & $\begin{array}{c}0.075 \\
(0.012)\end{array}$ & $\begin{array}{c}0.018 \\
(0.018)\end{array}$ & $\begin{array}{c}0.053 \\
(0.007)\end{array}$ & $\begin{array}{c}0.051 \\
(0.011)\end{array}$ \\
\hline Hispanic & $\begin{array}{c}0.031 \\
(0.016)\end{array}$ & $\begin{array}{c}0.153 \\
(0.019)\end{array}$ & $\begin{array}{c}0.028 \\
(0.014)\end{array}$ & $\begin{array}{c}0.103 \\
(0.021)\end{array}$ & $\begin{array}{c}0.140 \\
(0.022)\end{array}$ & $\begin{array}{c}0.106 \\
(0.027)\end{array}$ & $\begin{array}{c}0.054 \\
(0.010)\end{array}$ & $\begin{array}{c}0.058 \\
(0.013)\end{array}$ \\
\hline Other Race & $\begin{array}{c}0.002 \\
(0.023)\end{array}$ & $\begin{array}{c}0.010 \\
(0.029)\end{array}$ & $\begin{array}{l}-0.006 \\
(0.024)\end{array}$ & $\begin{array}{c}0.011 \\
(0.026)\end{array}$ & $\begin{array}{c}0.021 \\
(0.031)\end{array}$ & $\begin{array}{c}0.023 \\
(0.027)\end{array}$ & $\begin{array}{c}0.005 \\
(0.011)\end{array}$ & $\begin{array}{c}0.009 \\
(0.011)\end{array}$ \\
\hline Grade in School & $\begin{array}{c}0.020 \\
(0.011)\end{array}$ & $\begin{array}{l}-0.008 \\
(0.008)\end{array}$ & $\begin{array}{c}0.023 \\
(0.011)\end{array}$ & $\begin{array}{c}0.008 \\
(0.009)\end{array}$ & $\begin{array}{l}-0.042 \\
(0.010)\end{array}$ & $\begin{array}{c}-0.022 \\
(0.008)\end{array}$ & $\begin{array}{c}-0.013 \\
(0.004)\end{array}$ & $\begin{array}{l}-0.007 \\
(0.003)\end{array}$ \\
\hline \multicolumn{9}{|l|}{$\underline{\text { Geographic Variables }}$} \\
\hline $\begin{array}{l}\text { Teen Employment-to-Population Ratio } \\
\text { (x 10) }\end{array}$ & $\begin{array}{l}-0.112 \\
(0.031)\end{array}$ & $\begin{array}{l}-0.081 \\
(0.029)\end{array}$ & $\begin{array}{l}-0.106 \\
(0.024)\end{array}$ & $\begin{array}{l}-0.068 \\
(0.024)\end{array}$ & $\begin{array}{l}-0.011 \\
(0.024)\end{array}$ & $\begin{array}{c}0.016 \\
(0.027)\end{array}$ & $\begin{array}{l}-0.022 \\
(0.010)\end{array}$ & $\begin{array}{l}-0.002 \\
(0.009)\end{array}$ \\
\hline $\begin{array}{l}\text { Log Maximum AFDC/TANF } \\
\text { Benefit for a Family of } 2\end{array}$ & $\begin{array}{c}0.282 \\
(0.098)\end{array}$ & $\begin{array}{l}-0.021 \\
(0.133)\end{array}$ & $\begin{array}{c}0.073 \\
(0.090)\end{array}$ & $\begin{array}{c}0.296 \\
(0.118)\end{array}$ & $\begin{array}{l}0.301 \\
(0.086)\end{array}$ & $\begin{array}{l}0.081 \\
(0.108)\end{array}$ & $\begin{array}{c}0.121 \\
(0.039)\end{array}$ & $\begin{array}{c}0.072 \\
(0.039)\end{array}$ \\
\hline Reformed Welfare System & $\begin{array}{c}0.104 \\
(0.028)\end{array}$ & $\begin{array}{c}0.059 \\
(0.024)\end{array}$ & $\begin{array}{c}0.078 \\
(0.021)\end{array}$ & $\begin{array}{c}0.037 \\
(0.019)\end{array}$ & $\begin{array}{l}0.013 \\
(0.020)\end{array}$ & $\begin{array}{l}-0.048 \\
(0.021)\end{array}$ & $\begin{array}{c}0.017 \\
(0.008)\end{array}$ & $\begin{array}{l}-0.012 \\
(0.076)\end{array}$ \\
\hline $\begin{array}{l}\text { Aids Rate per 100,000 Population } \\
\text { (x 100) }\end{array}$ & $\begin{array}{l}-0.259 \\
(0.103)\end{array}$ & $\begin{array}{l}-0.052 \\
(0.091)\end{array}$ & $\begin{array}{l}-0.072 \\
(0.087)\end{array}$ & $\begin{array}{l}-0.064 \\
(0.070)\end{array}$ & $\begin{array}{l}-0.007 \\
(0.080)\end{array}$ & $\begin{array}{l}-0.061 \\
(0.083)\end{array}$ & $\begin{array}{l}-0.025 \\
(0.031)\end{array}$ & $\begin{array}{l}-0.024 \\
(0.031)\end{array}$ \\
\hline Medicaid Funding Restrictions & $\begin{array}{l}-0.013 \\
(0.101)\end{array}$ & $\begin{array}{c}0.023 \\
(0.044)\end{array}$ & $\begin{array}{l}-0.011 \\
(0.084)\end{array}$ & $\begin{array}{l}-0.008 \\
(0.017)\end{array}$ & $\begin{array}{l}-0.066 \\
(0.055)\end{array}$ & $\begin{array}{l}0.015 \\
(0.026)\end{array}$ & $\begin{array}{l}-0.017 \\
(0.026)\end{array}$ & $\begin{array}{c}0.006 \\
(0.009)\end{array}$ \\
\hline $\begin{array}{l}\text { Mandatory Waiting Period } \\
\text { for Abortion }\end{array}$ & $\begin{array}{c}0.014 \\
(0.054)\end{array}$ & $\begin{array}{l}-0.062 \\
(0.051)\end{array}$ & $\begin{array}{c}0.019 \\
(0.040)\end{array}$ & $\begin{array}{l}-0.027 \\
(0.042)\end{array}$ & $\begin{array}{l}-0.021 \\
(0.032)\end{array}$ & $\begin{array}{l}-0.021 \\
(0.029)\end{array}$ & $\begin{array}{l}-0.005 \\
(0.014)\end{array}$ & $\begin{array}{l}-0.011 \\
(0.010)\end{array}$ \\
\hline Sample Size & 27,137 & 25,623 & 27,137 & 25,623 & 10,610 & 10,508 & 27,137 & 25,623 \\
\hline
\end{tabular}

Source: Author's calculations from the 1991, 1993, 1995, and 1997 Youth Risk Behavior Survey. 
Table 4: The Relationship between Geographic Factors and Teen Sexual Activity, Contraception, and Pregnancy, by Race and Ethnicity

(Probit Derivatives, Standard Errors in Parentheses)

\begin{tabular}{|c|c|c|c|c|c|c|c|c|}
\hline \multirow[b]{2}{*}{ Geographic Variables } & \multicolumn{2}{|c|}{ Sexual Intercourse Ever } & \multicolumn{2}{|c|}{$\begin{array}{l}\text { Sexual Intercourse in } \\
\text { Past Three Months }\end{array}$} & \multicolumn{2}{|c|}{$\begin{array}{l}\text { No Contraception Used } \\
\text { at Last Intercourse in } \\
\text { Past } 3 \text { Months }\end{array}$} & \multicolumn{2}{|c|}{ "Pregnancy Risk" } \\
\hline & $\begin{array}{c}\text { Girls } \\
(1)\end{array}$ & $\begin{array}{l}\text { Boys } \\
(2)\end{array}$ & $\begin{array}{c}\text { Girls } \\
(3)\end{array}$ & $\begin{array}{l}\text { Boys } \\
(4)\end{array}$ & $\begin{array}{c}\text { Girls } \\
(5)\end{array}$ & $\begin{array}{l}\text { Boys } \\
(6)\end{array}$ & $\begin{array}{l}\text { Girls } \\
(7)\end{array}$ & $\begin{array}{c}\text { Boys } \\
(8)\end{array}$ \\
\hline $\begin{array}{l}\text { Employment-to-Population Ratio } \\
\text { (x 10) }\end{array}$ & $\begin{array}{l}-0.123 \\
(0.033)\end{array}$ & $\begin{array}{l}-0.088 \\
(0.029)\end{array}$ & $\begin{array}{l}-0.114 \\
(0.026)\end{array}$ & $\begin{array}{l}-0.082 \\
(0.025)\end{array}$ & $\begin{array}{l}0.006 \\
(0.027)\end{array}$ & $\begin{array}{c}0.049 \\
(0.029)\end{array}$ & $\begin{array}{l}-0.015 \\
(0.011)\end{array}$ & $\begin{array}{c}0.005 \\
(0.010)\end{array}$ \\
\hline * Black, non-Hispanic & $\begin{array}{c}0.035 \\
(0.038)\end{array}$ & $\begin{array}{c}0.022 \\
(0.035)\end{array}$ & $\begin{array}{l}0.021 \\
(0.033)\end{array}$ & $\begin{array}{c}0.026 \\
(0.028)\end{array}$ & $\begin{array}{l}-0.049 \\
(0.020)\end{array}$ & $\begin{array}{l}-0.099 \\
(0.027)\end{array}$ & $\begin{array}{l}-0.015 \\
(0.009)\end{array}$ & $\begin{array}{l}-0.029 \\
(0.009)\end{array}$ \\
\hline * Hispanic & $\begin{array}{l}-0.004 \\
(0.028)\end{array}$ & $\begin{array}{c}0.031 \\
(0.047)\end{array}$ & $\begin{array}{l}0.018 \\
(0.026)\end{array}$ & $\begin{array}{c}0.004 \\
(0.036)\end{array}$ & $\begin{array}{l}-0.057 \\
(0.038)\end{array}$ & $\begin{array}{l}-0.086 \\
(0.040)\end{array}$ & $\begin{array}{l}-0.020 \\
(0.013)\end{array}$ & $\begin{array}{l}-0.020 \\
(0.013)\end{array}$ \\
\hline $\begin{array}{l}\text { Log Maximum AFDC/TANF } \\
\text { Benefit for a Family of } 2\end{array}$ & $\begin{array}{c}0.281 \\
(0.106)\end{array}$ & $\begin{array}{l}-0.016 \\
(0.137)\end{array}$ & $\begin{array}{c}0.068 \\
(0.094)\end{array}$ & $\begin{array}{c}0.312 \\
(0.119)\end{array}$ & $\begin{array}{c}0.317 \\
(0.090)\end{array}$ & $\begin{array}{c}0.078 \\
(0.104)\end{array}$ & $\begin{array}{c}0.121 \\
(0.037)\end{array}$ & $\begin{array}{c}0.068 \\
(0.038)\end{array}$ \\
\hline * Black, non-Hispanic & $\begin{array}{c}0.049 \\
(0.058)\end{array}$ & $\begin{array}{l}-0.040 \\
(0.063)\end{array}$ & $\begin{array}{l}-0.010 \\
(0.047)\end{array}$ & $\begin{array}{c}0.019 \\
(0.054)\end{array}$ & $\begin{array}{c}0.057 \\
(0.028)\end{array}$ & $\begin{array}{l}0.080 \\
(0.047)\end{array}$ & $\begin{array}{c}0.024 \\
(0.013)\end{array}$ & $\begin{array}{c}0.033 \\
(0.018)\end{array}$ \\
\hline * Hispanic & $\begin{array}{c}0.053 \\
(0.056)\end{array}$ & $\begin{array}{l}-0.008 \\
(0.074)\end{array}$ & $\begin{array}{c}0.019 \\
(0.048)\end{array}$ & $\begin{array}{l}-0.019 \\
(0.053)\end{array}$ & $\begin{array}{c}0.038 \\
(0.051)\end{array}$ & $\begin{array}{c}0.032 \\
(0.077)\end{array}$ & $\begin{array}{l}0.015 \\
(0.020)\end{array}$ & $\begin{array}{c}0.012 \\
(0.026)\end{array}$ \\
\hline Reformed Welfare System & $\begin{array}{c}0.102 \\
(0.030)\end{array}$ & $\begin{array}{c}0.059 \\
(0.027)\end{array}$ & $\begin{array}{c}0.079 \\
(0.024)\end{array}$ & $\begin{array}{c}0.033 \\
(0.022)\end{array}$ & $\begin{array}{c}0.005 \\
(0.021)\end{array}$ & $\begin{array}{l}-0.070 \\
(0.027)\end{array}$ & $\begin{array}{c}0.014 \\
(0.009)\end{array}$ & $\begin{array}{l}-0.019 \\
(0.009)\end{array}$ \\
\hline * Black, non-Hispanic & $\begin{array}{l}-0.019 \\
(0.030)\end{array}$ & $\begin{array}{l}-0.003 \\
(0.043)\end{array}$ & $\begin{array}{l}-0.032 \\
(0.030)\end{array}$ & $\begin{array}{c}0.041 \\
(0.036)\end{array}$ & $\begin{array}{c}0.038 \\
(0.025)\end{array}$ & $\begin{array}{c}0.035 \\
(0.036)\end{array}$ & $\begin{array}{c}0.010 \\
(0.011)\end{array}$ & $\begin{array}{c}0.016 \\
(0.013)\end{array}$ \\
\hline * Hispanic & $\begin{array}{c}0.012 \\
(0.028)\end{array}$ & $\begin{array}{l}-0.045 \\
(0.052)\end{array}$ & $\begin{array}{c}0.009 \\
(0.027)\end{array}$ & $\begin{array}{l}-0.077 \\
(0.038)\end{array}$ & $\begin{array}{l}-0.007 \\
(0.035)\end{array}$ & $\begin{array}{c}0.035 \\
(0.048)\end{array}$ & $\begin{array}{c}0.013 \\
(0.012)\end{array}$ & $\begin{array}{c}0.002 \\
(0.017)\end{array}$ \\
\hline $\begin{array}{l}\text { Aids Rate per 100,000 } \\
\text { Population (x 100) }\end{array}$ & $\begin{array}{l}-0.224 \\
(0.106)\end{array}$ & $\begin{array}{l}-0.044 \\
(0.093)\end{array}$ & $\begin{array}{l}-0.049 \\
(0.087)\end{array}$ & $\begin{array}{l}-0.056 \\
(0.081)\end{array}$ & $\begin{array}{l}0.015 \\
(0.083)\end{array}$ & $\begin{array}{l}-0.026 \\
(0.093)\end{array}$ & $\begin{array}{l}-0.006 \\
(0.031)\end{array}$ & $\begin{array}{l}-0.017 \\
(0.035)\end{array}$ \\
\hline $\begin{array}{l}* \text { Black, non-Hispanic } \\
\text { (x 100) }\end{array}$ & $\begin{array}{l}-0.061 \\
(0.086)\end{array}$ & $\begin{array}{c}0.097 \\
(0.101)\end{array}$ & $\begin{array}{c}0.003 \\
(0.087)\end{array}$ & $\begin{array}{c}0.006 \\
(0.085)\end{array}$ & $\begin{array}{c}0.015 \\
(0.083)\end{array}$ & $\begin{array}{l}-0.108 \\
(0.067)\end{array}$ & $\begin{array}{c}0.012 \\
(0.024)\end{array}$ & $\begin{array}{l}-0.036 \\
(0.028)\end{array}$ \\
\hline $\begin{array}{l}* \text { Hispanic } \\
\text { (x 100) }\end{array}$ & $\begin{array}{l}-0.012 \\
(0.091)\end{array}$ & $\begin{array}{l}-0.008 \\
(0.101)\end{array}$ & $\begin{array}{c}0.000 \\
(0.086)\end{array}$ & $\begin{array}{l}-0.057 \\
(0.075)\end{array}$ & $\begin{array}{l}-0.257 \\
(0.070)\end{array}$ & $\begin{array}{l}-0.033 \\
(0.094)\end{array}$ & $\begin{array}{l}-0.083 \\
(0.028)\end{array}$ & $\begin{array}{l}-0.011 \\
(0.033)\end{array}$ \\
\hline Medicaid Funding Restrictions & $\begin{array}{l}-0.013 \\
(0.104)\end{array}$ & $\begin{array}{c}0.026 \\
(0.046)\end{array}$ & $\begin{array}{c}0.007 \\
(0.084)\end{array}$ & $\begin{array}{l}-0.007 \\
(0.020)\end{array}$ & $\begin{array}{l}-0.109 \\
(0.062)\end{array}$ & $\begin{array}{l}-0.026 \\
(0.028)\end{array}$ & $\begin{array}{l}-0.029 \\
(0.030)\end{array}$ & $\begin{array}{l}-0.007 \\
(0.010)\end{array}$ \\
\hline * Black, non-Hispanic & $\begin{array}{c}0.014 \\
(0.061)\end{array}$ & $\begin{array}{c}0.020 \\
(0.066)\end{array}$ & $\begin{array}{l}-0.052 \\
(0.046)\end{array}$ & $\begin{array}{l}-0.003 \\
(0.056)\end{array}$ & $\begin{array}{l}0.158 \\
(0.048)\end{array}$ & $\begin{array}{c}0.159 \\
(0.070)\end{array}$ & $\begin{array}{l}0.055 \\
(0.024)\end{array}$ & $\begin{array}{c}0.062 \\
(0.032)\end{array}$ \\
\hline * Hispanic & $\begin{array}{l}-0.008 \\
(0.059)\end{array}$ & $\begin{array}{l}-0.115 \\
(0.078)\end{array}$ & $\begin{array}{l}-0.035 \\
(0.047)\end{array}$ & $\begin{array}{l}-0.078 \\
(0.050)\end{array}$ & $\begin{array}{l}-0.015 \\
(0.054)\end{array}$ & $\begin{array}{c}0.082 \\
(0.102)\end{array}$ & $\begin{array}{l}-0.009 \\
(0.019)\end{array}$ & $\begin{array}{c}0.012 \\
(0.028)\end{array}$ \\
\hline $\begin{array}{l}\text { Parental Consent/Notification } \\
\text { Required for Abortion }\end{array}$ & $\begin{array}{l}-0.031 \\
(0.049)\end{array}$ & $\begin{array}{c}0.061 \\
(0.031)\end{array}$ & $\begin{array}{l}-0.011 \\
(0.036)\end{array}$ & $\begin{array}{c}0.020 \\
(0.031)\end{array}$ & $\begin{array}{c}0.048 \\
(0.025)\end{array}$ & $\begin{array}{l}-0.007 \\
(0.038)\end{array}$ & $\begin{array}{c}0.016 \\
(0.013)\end{array}$ & $\begin{array}{c}0.002 \\
(0.014)\end{array}$ \\
\hline * Black, non-Hispanic & $\begin{array}{c}0.038 \\
(0.044)\end{array}$ & $\begin{array}{c}0.031 \\
(0.048)\end{array}$ & $\begin{array}{c}0.028 \\
(0.042)\end{array}$ & $\begin{array}{c}0.023 \\
(0.041)\end{array}$ & $\begin{array}{l}-0.008 \\
(0.024)\end{array}$ & $\begin{array}{l}-0.001 \\
(0.036)\end{array}$ & $\begin{array}{c}0.001 \\
(0.011)\end{array}$ & $\begin{array}{l}-0.003 \\
(0.014)\end{array}$ \\
\hline * Hispanic & $\begin{array}{l}-0.027 \\
(0.044)\end{array}$ & $\begin{array}{l}-0.023 \\
(0.083)\end{array}$ & $\begin{array}{l}-0.004 \\
(0.041)\end{array}$ & $\begin{array}{c}-0.002 \\
(0.062)\end{array}$ & $\begin{array}{l}-0.070 \\
(0.044)\end{array}$ & $\begin{array}{l}0.110 \\
(0.095)\end{array}$ & $\begin{array}{l}-0.024 \\
(0.015)\end{array}$ & $\begin{array}{c}0.024 \\
(0.032)\end{array}$ \\
\hline $\begin{array}{l}\text { Mandatory Waiting Period } \\
\text { for Abortion }\end{array}$ & $\begin{array}{c}0.049 \\
(0.059)\end{array}$ & $\begin{array}{l}-0.075 \\
(0.052)\end{array}$ & $\begin{array}{c}0.029 \\
(0.046)\end{array}$ & $\begin{array}{l}-0.036 \\
(0.043)\end{array}$ & $\begin{array}{l}-0.006 \\
(0.037)\end{array}$ & $\begin{array}{l}-0.023 \\
(0.039)\end{array}$ & $\begin{array}{c}0.002 \\
(0.019)\end{array}$ & $\begin{array}{l}-0.014 \\
(0.010)\end{array}$ \\
\hline * Black, non-Hispanic & $\begin{array}{l}-0.091 \\
(0.050)\end{array}$ & $\begin{array}{l}-0.004 \\
(0.073)\end{array}$ & $\begin{array}{l}-0.050 \\
(0.039)\end{array}$ & $\begin{array}{l}-0.016 \\
(0.056)\end{array}$ & $\begin{array}{l}-0.064 \\
(0.020)\end{array}$ & $\begin{array}{l}-0.046 \\
(0.052)\end{array}$ & $\begin{array}{l}-0.026 \\
(0.009)\end{array}$ & $\begin{array}{l}-0.014 \\
(0.015)\end{array}$ \\
\hline * Hispanic & $\begin{array}{l}-0.063 \\
(0.052)\end{array}$ & $\begin{array}{c}0.271 \\
(0.110)\end{array}$ & $\begin{array}{l}-0.054 \\
(0.066)\end{array}$ & $\begin{array}{c}0.269 \\
(0.148)\end{array}$ & $\begin{array}{c}0.231 \\
(0.180)\end{array}$ & $\begin{array}{c}0.173 \\
(0.161)\end{array}$ & $\begin{array}{c}0.062 \\
(0.075)\end{array}$ & $\begin{array}{c}0.132 \\
(0.119)\end{array}$ \\
\hline
\end{tabular}

Source: Author's calculations from the 1991, 1993, 1995, and 1997 Youth Risk Behavior Survey.

Notes: All specifications include the same additional control variables as those reported in Table 3. 
Figure 1A: Birth, Pregnancy, and Abortion Rates for Women Aged 15 to 19

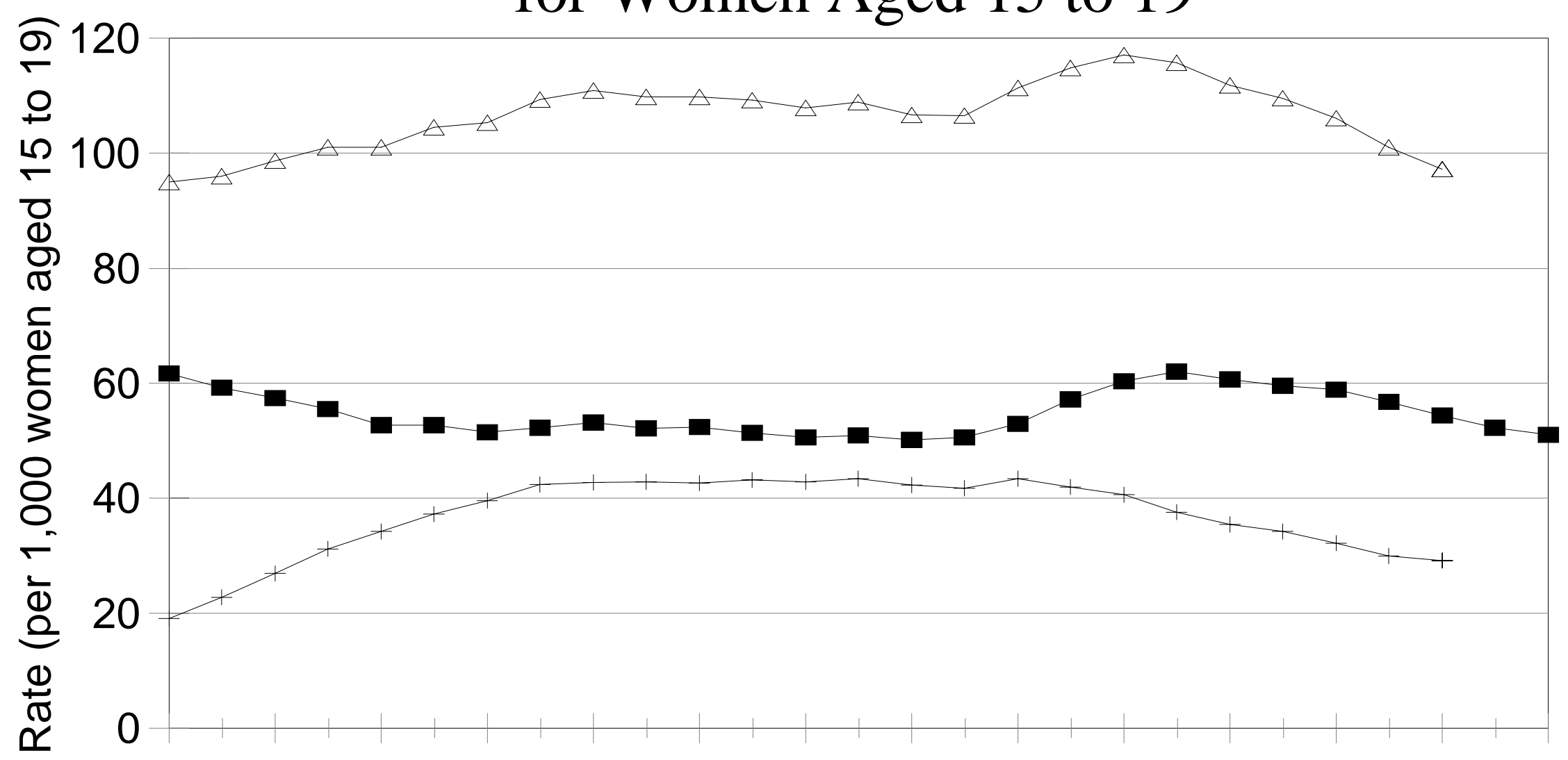

19721974197619781980198219841986198819901992199419961998 Year
- Birth Rate
Pregnancy Rate
Abortion Rate

Source: Henshaw (1999) and Ventura 1999b. 
Figure 1B: Birth, Pregnancy, and Abortion Rates for Women Aged 15 to 17

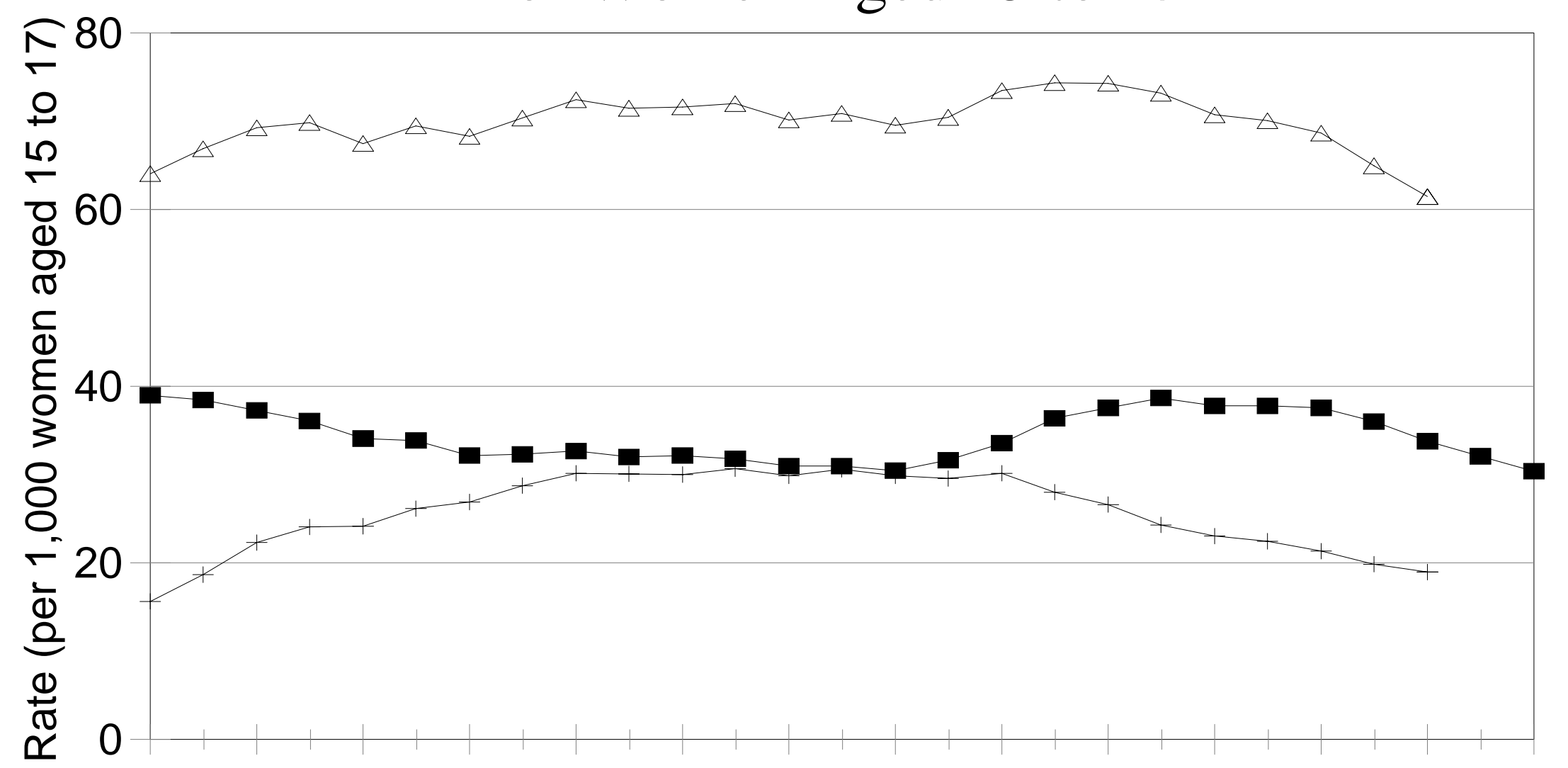

19721974197619781980198219841986198819901992199419961998 Year

- Birth Rate

Pregnancy Rate Abortion Rate

Source: Henshaw (1999) and Ventura 1999b. 


\section{Figure 2A: Birth Rates for Women Aged 15-19, by Race/Ethnicity}

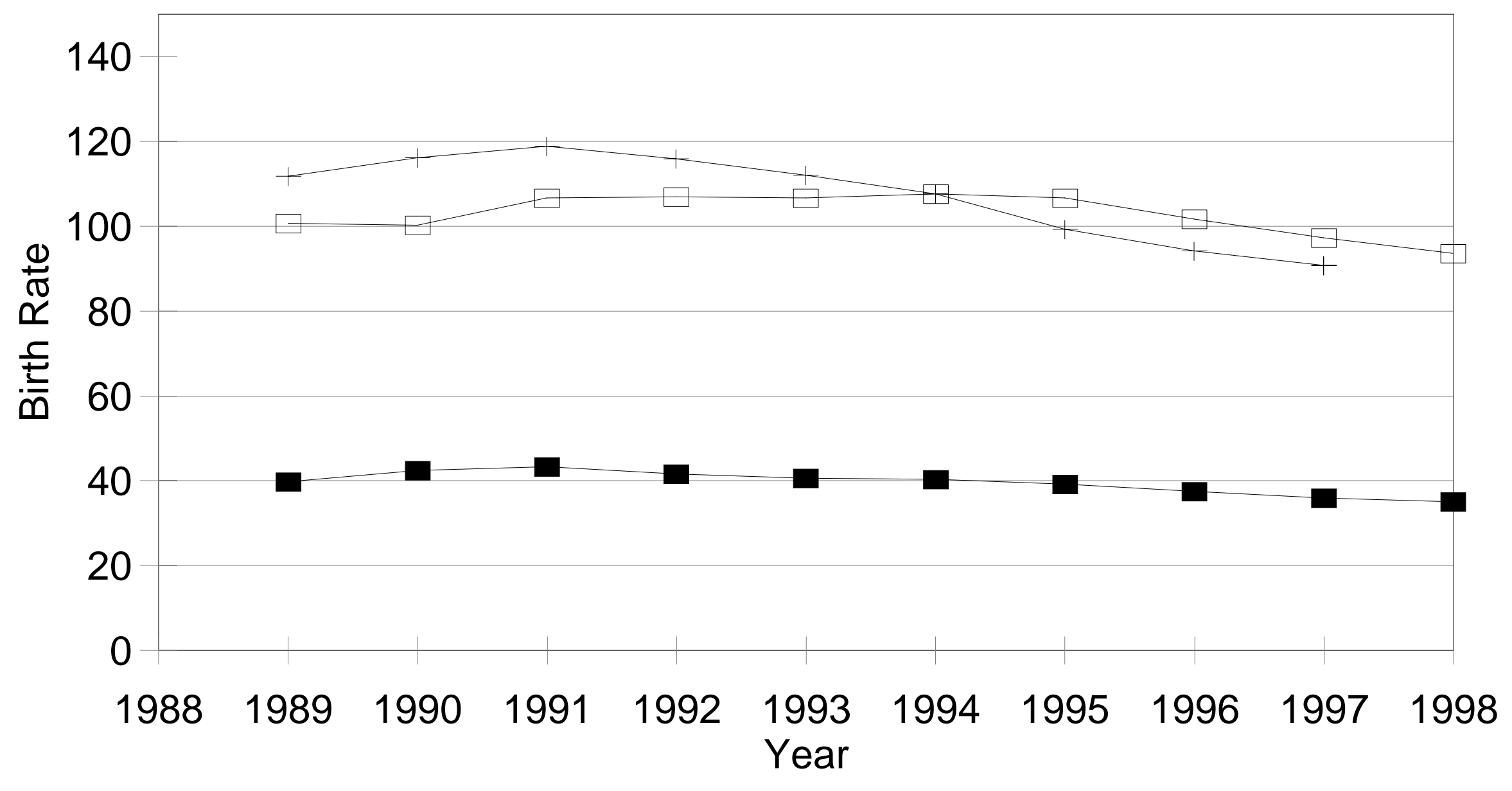

- white, non-Hisp. $\_$black, non-Hisp. $\square$ Hispanic

Source: Ventura, et al., 1999a and 1999b. 


\section{Figure 2B: Birth Rates for Women Aged 15-17, by Race/Ethnicity}

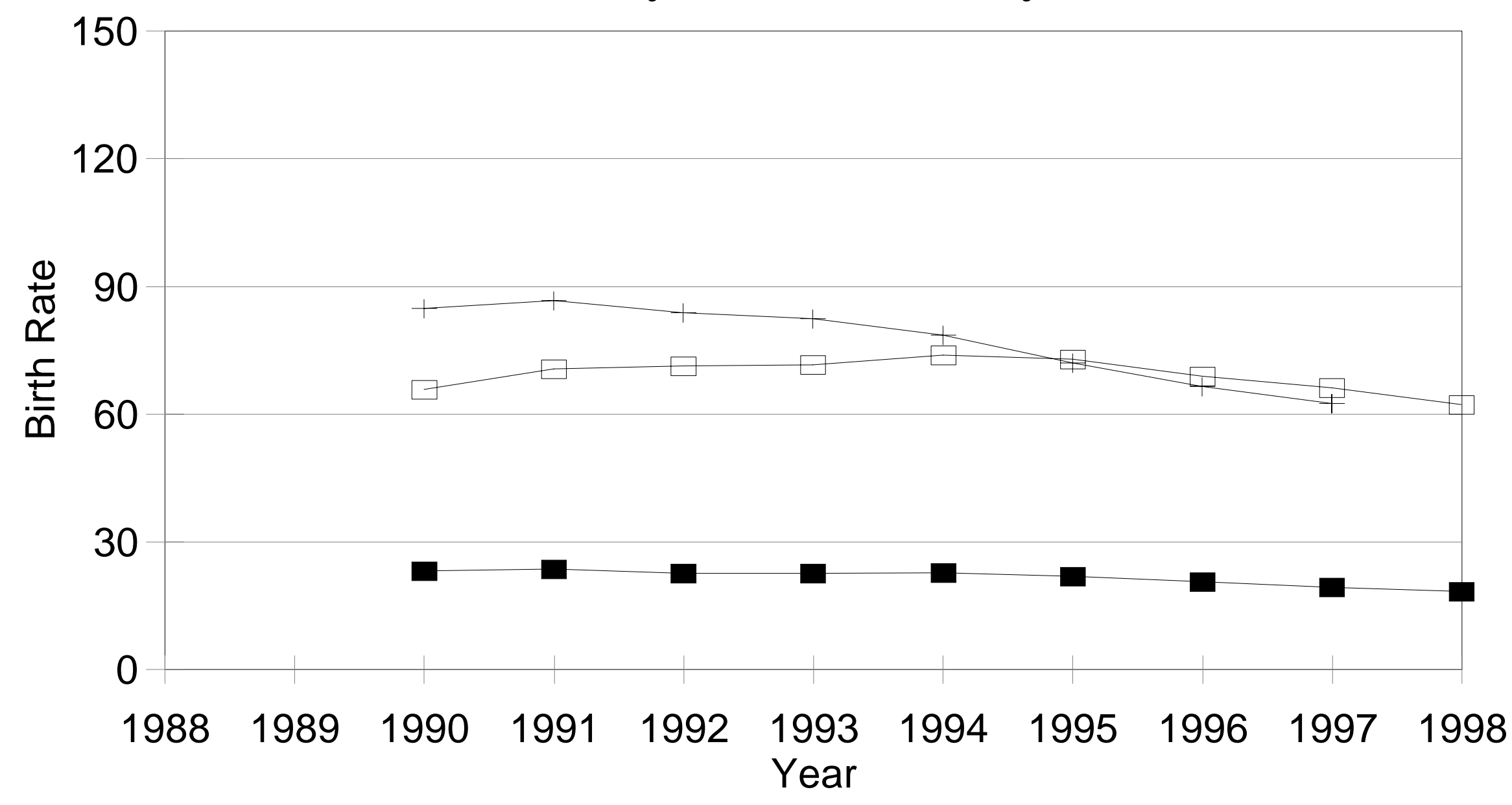

- white, non-Hisp. $\_$black, non-Hisp. $\square$ Hispanic

Source: Ventura, et al., 1999a and 1999b. 
Figure 3A: Percentage of Teen and Non-Teen

\section{Births to Unmarried Mothers}

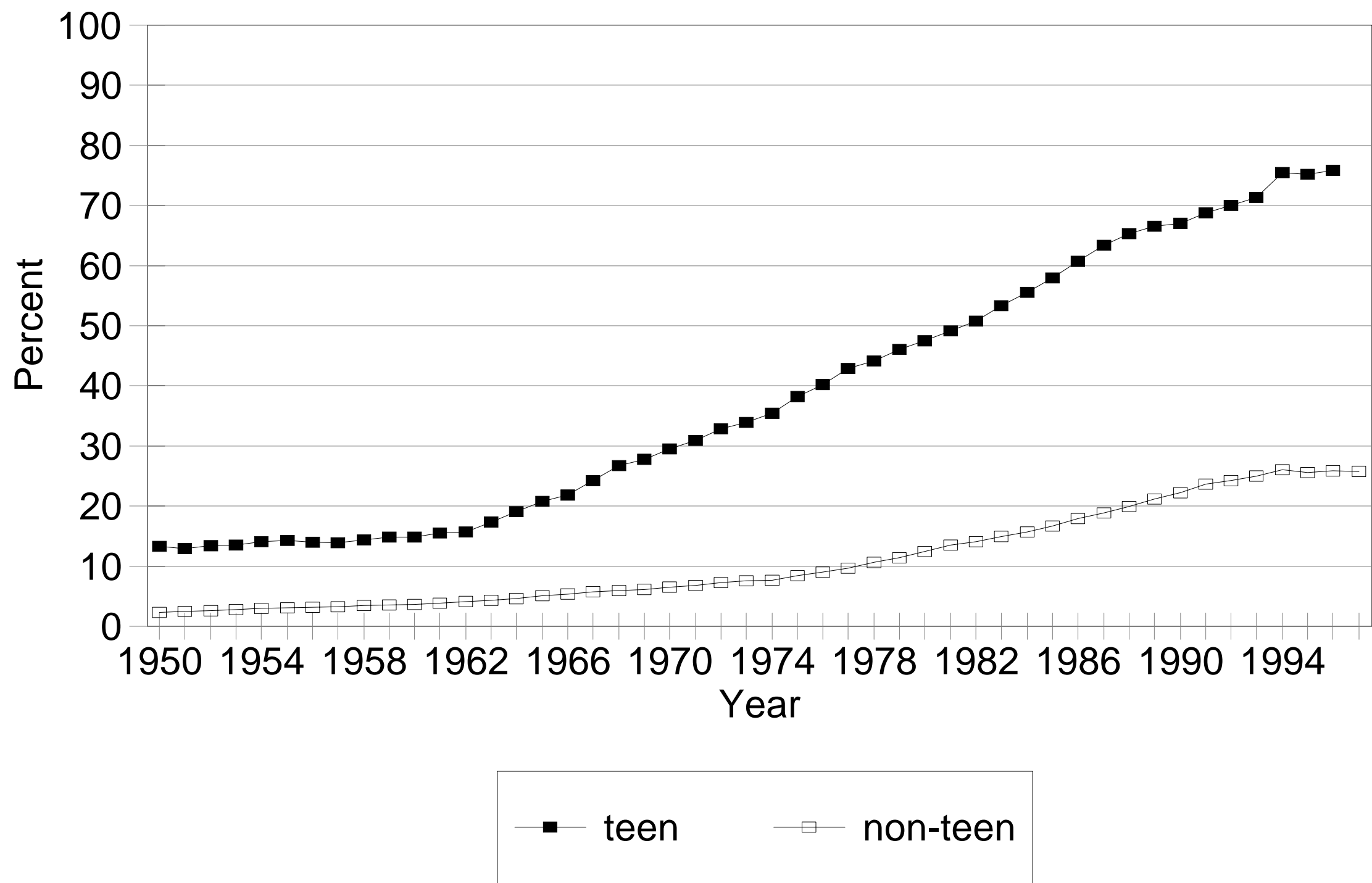

Sources: U.S. Department of Health and Human Services, 1995 and 1998; and Ventura, et al. 1999. 
Figure 3B: Percentage of Teen Births to Unmarried Mothers, by Race/Ethnicity

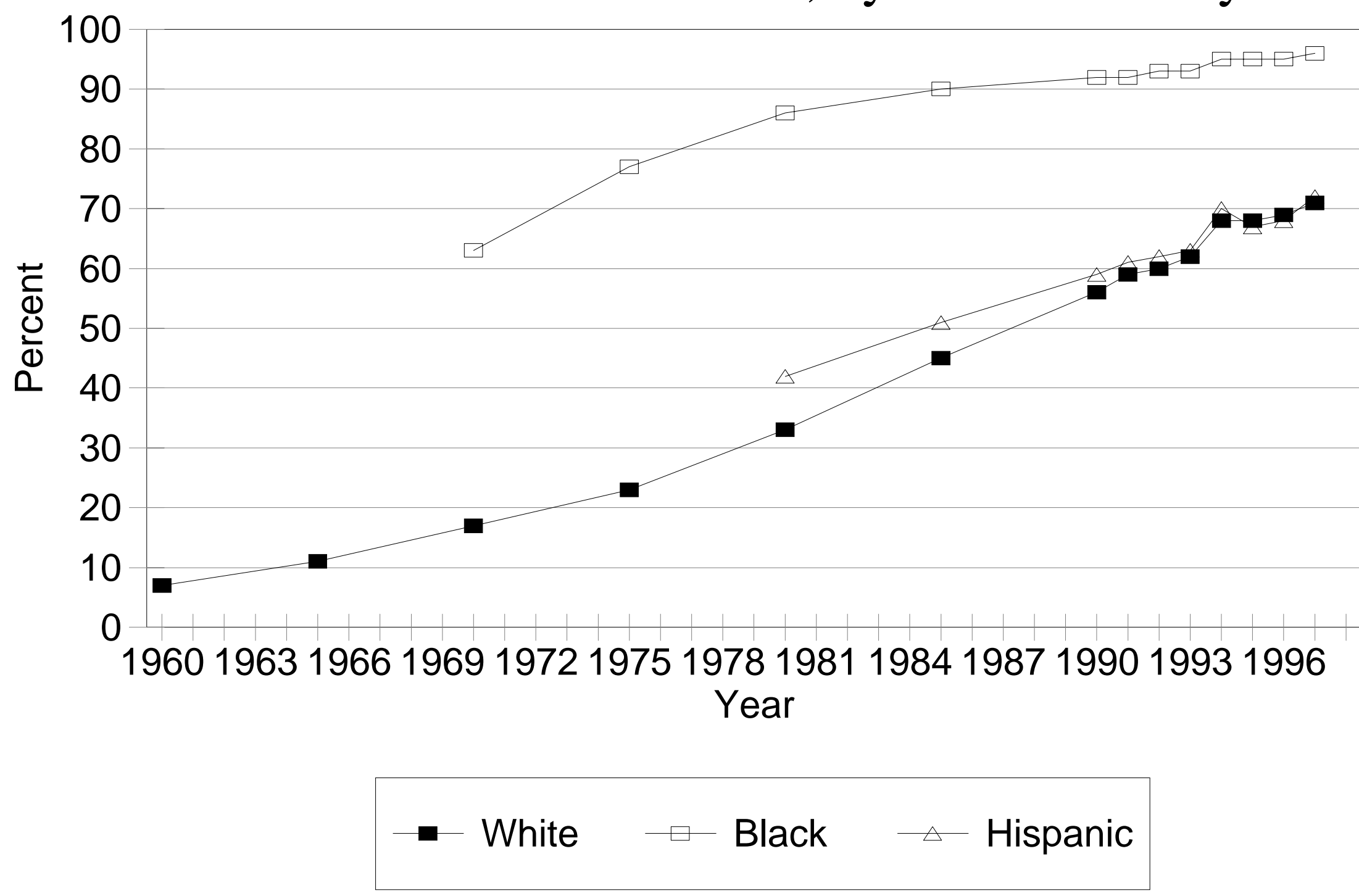

Sources: U.S. Department of Health and Human Services, 1998; and Ventura, et al. 1999. 
Figure 4: Teen Fertility Rates in the United States and Other Industrialized Countries

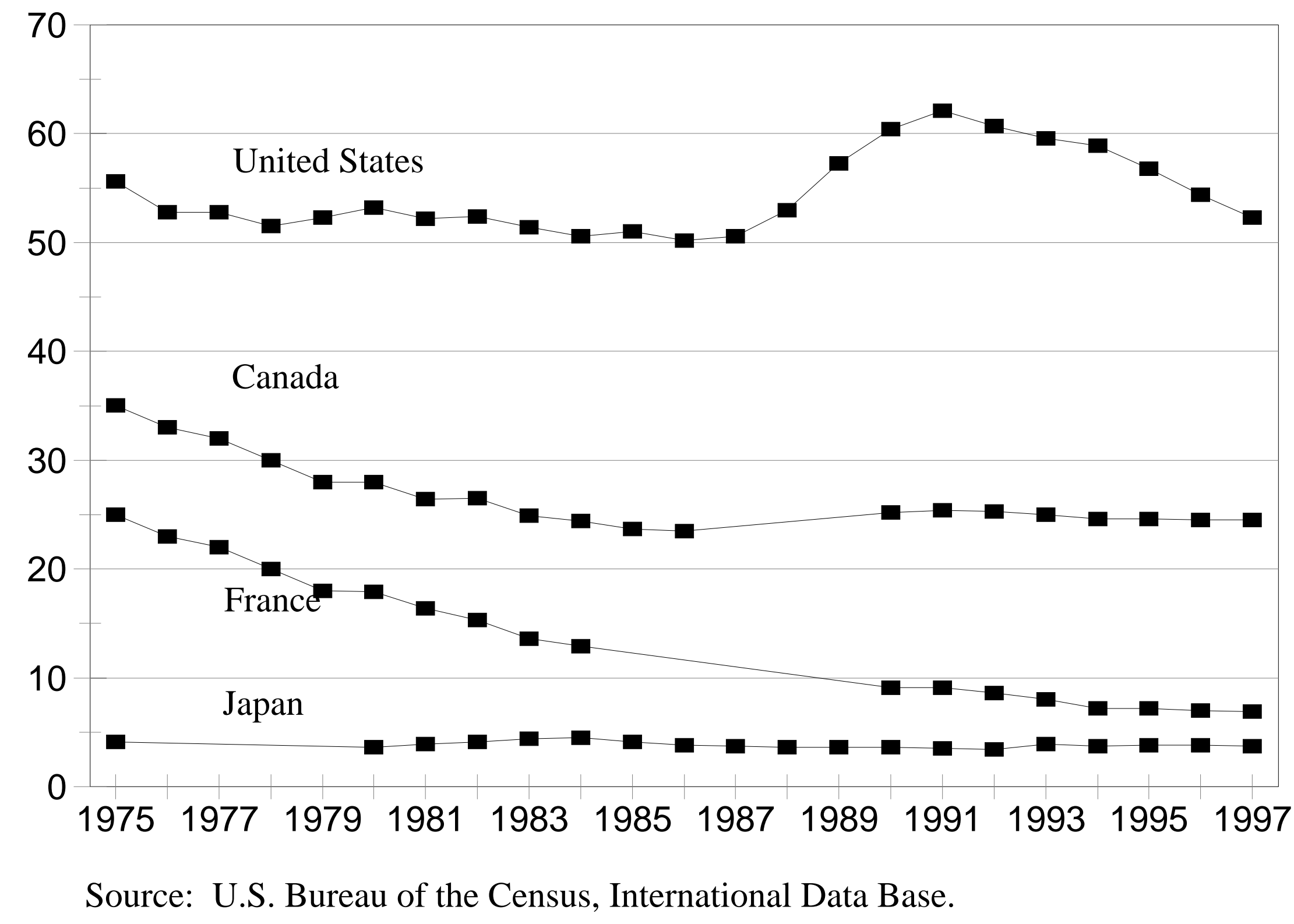


Figure 5: Birth, Abortion, and Pregnancy Rates in the United States and Other Developed Countries

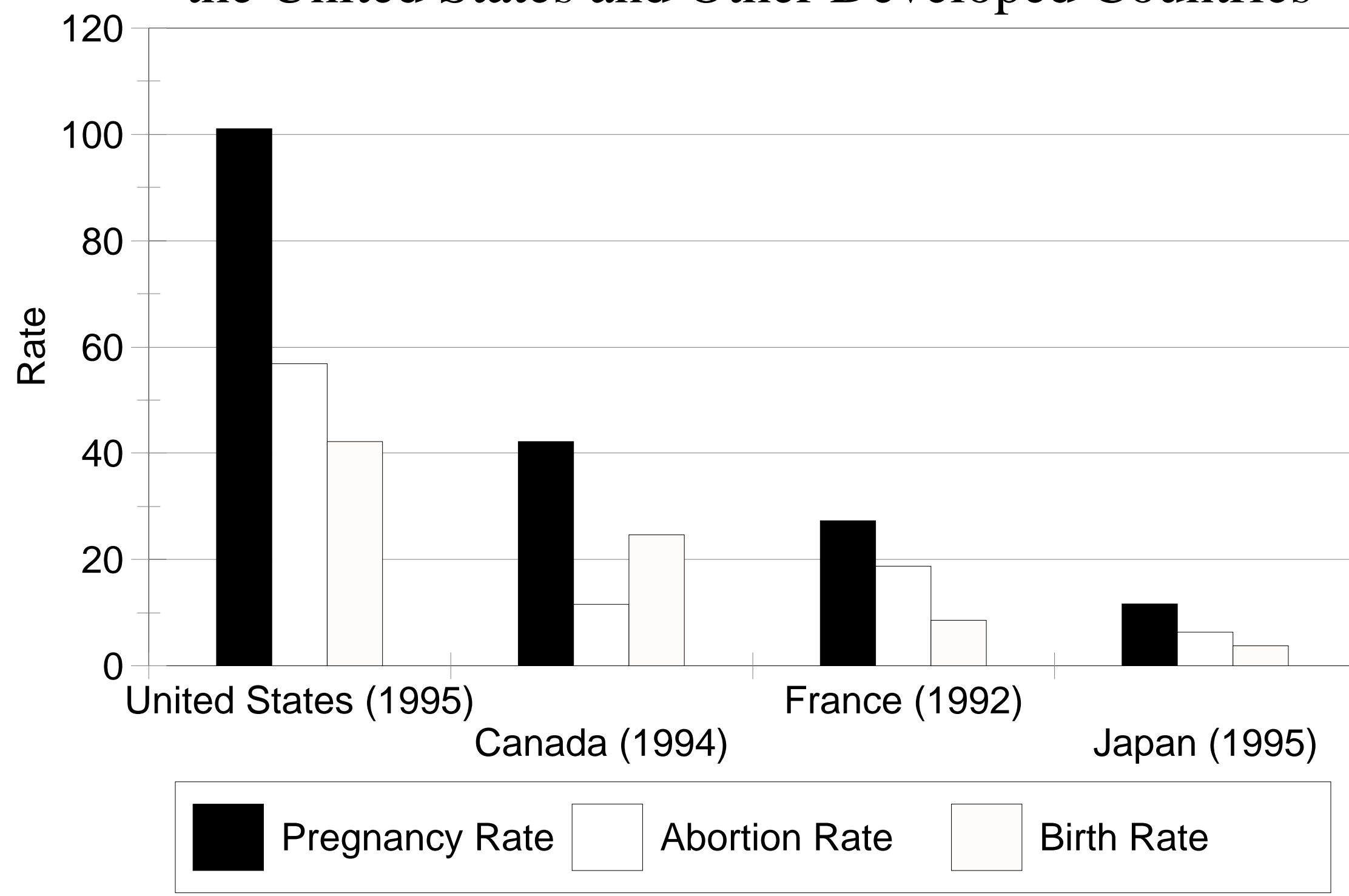

Source: United Nations, Department of Economic and Social Affairs, Statistical Office, various years 
Figure 6A: Percentage of Teens that Have Had Sexual Intercourse in the Last 3 Months

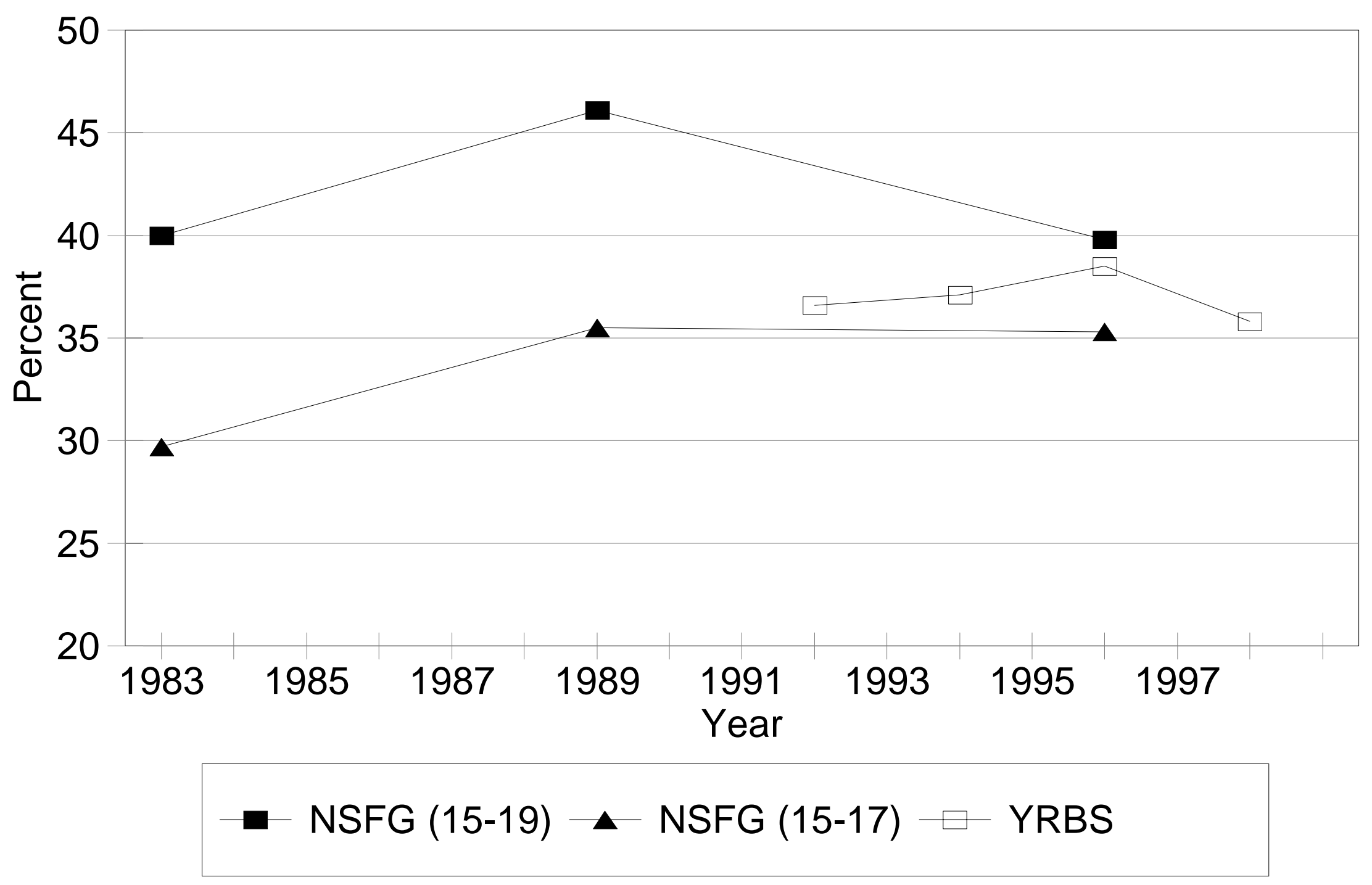

Source: Author's calculations from the NSFG and YRBS. 


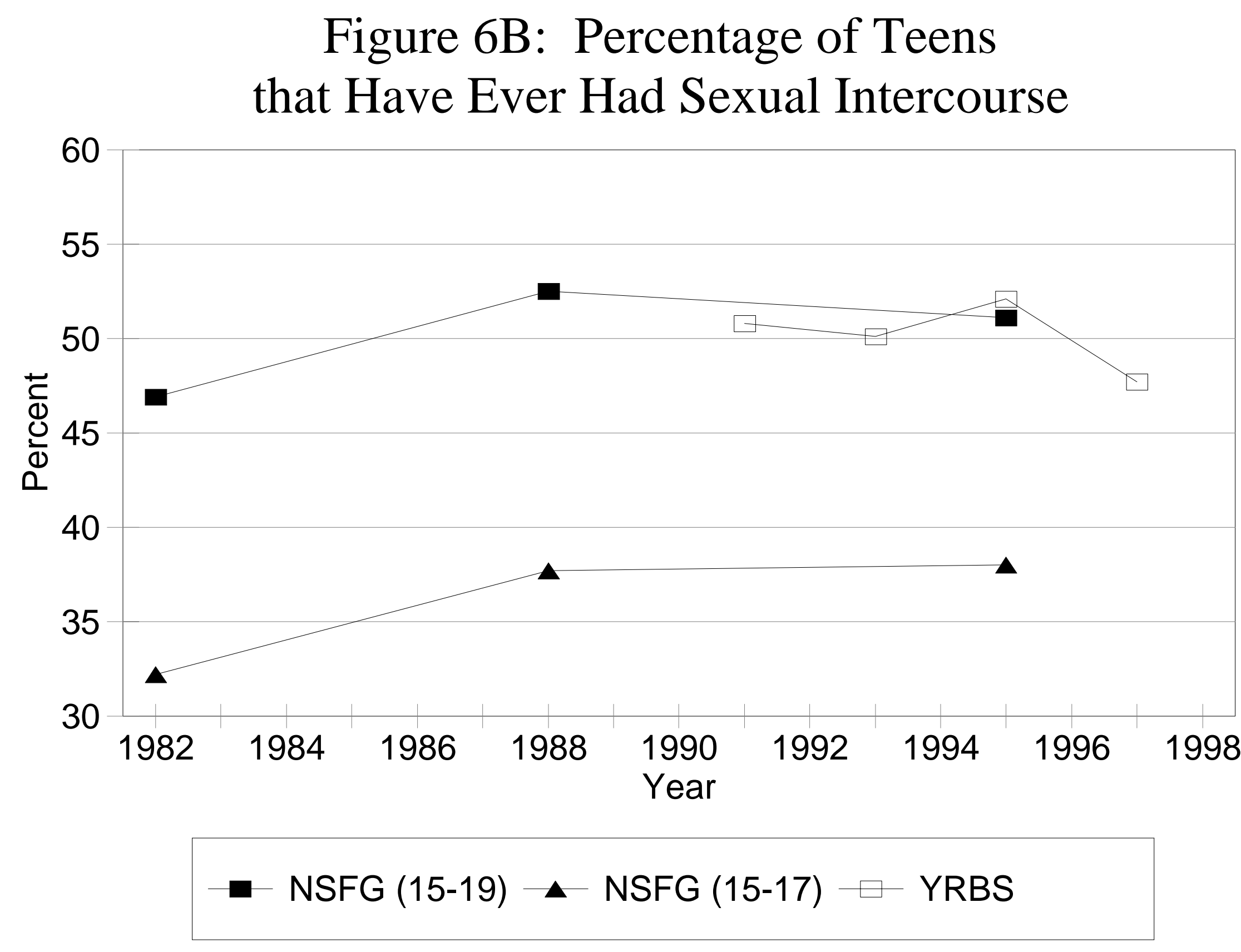

Source: Author's calculations from the NSFG and YRBS. 
Figure 7A: Percentage of Teens Who Failed to Use Contraception at Last Intercourse in Past 3 Months

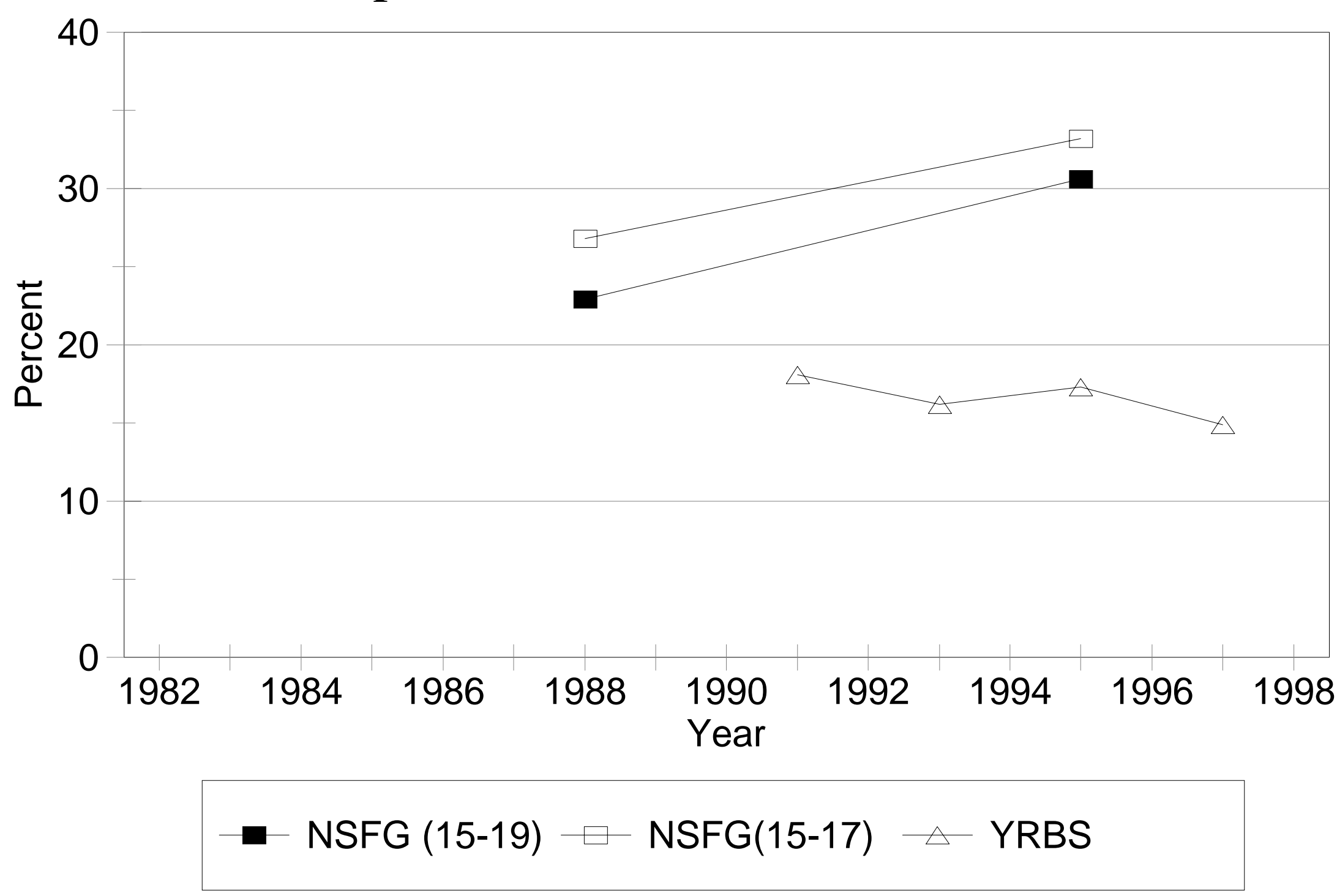

Source: Author's calculations from the NSFG and YRBS. 


\section{Figure 7B: Contraceptive Methods Used at Last Intercourse by 15 to 19 Year Old Women}

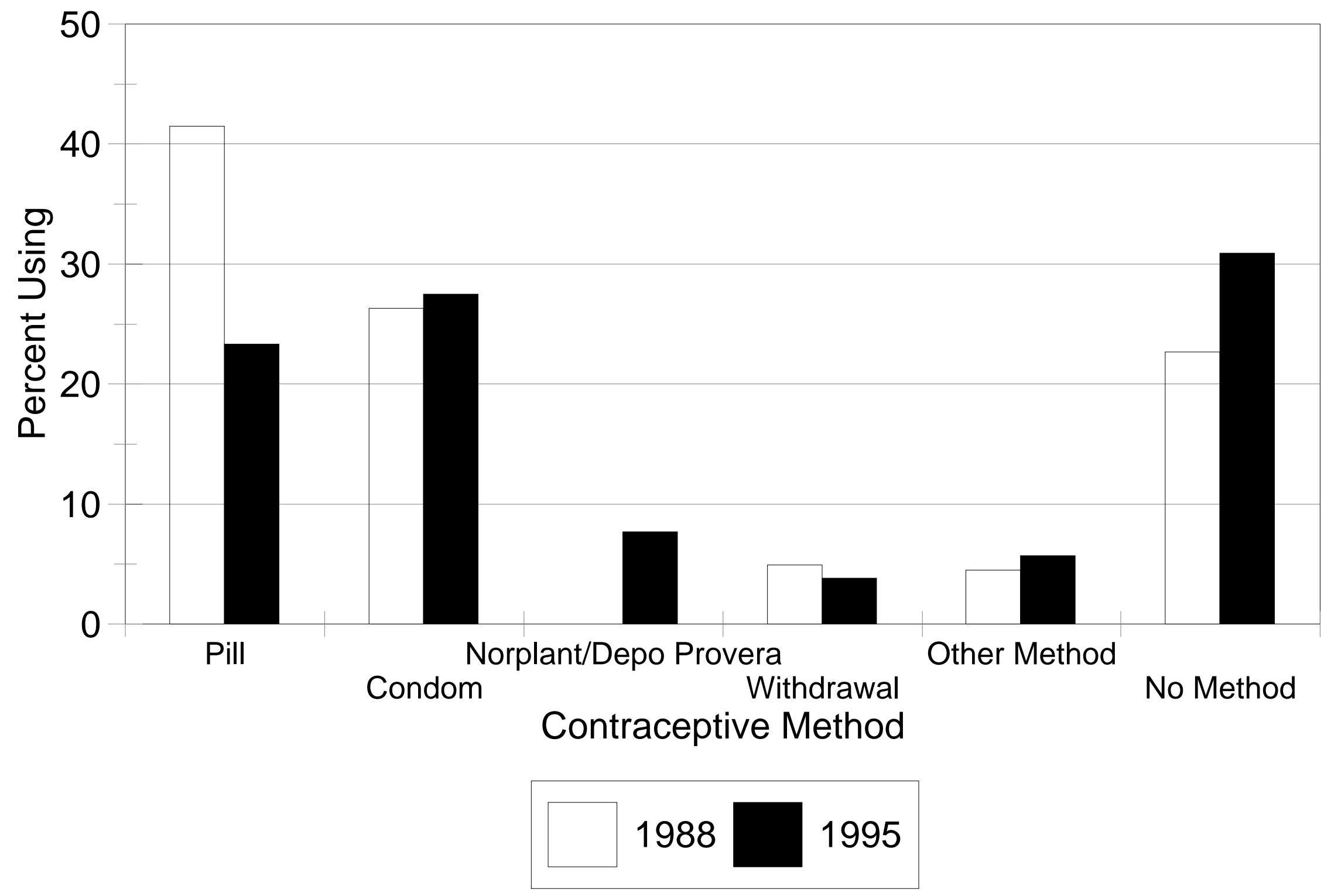

Source: Terry and Manlove, 1999 


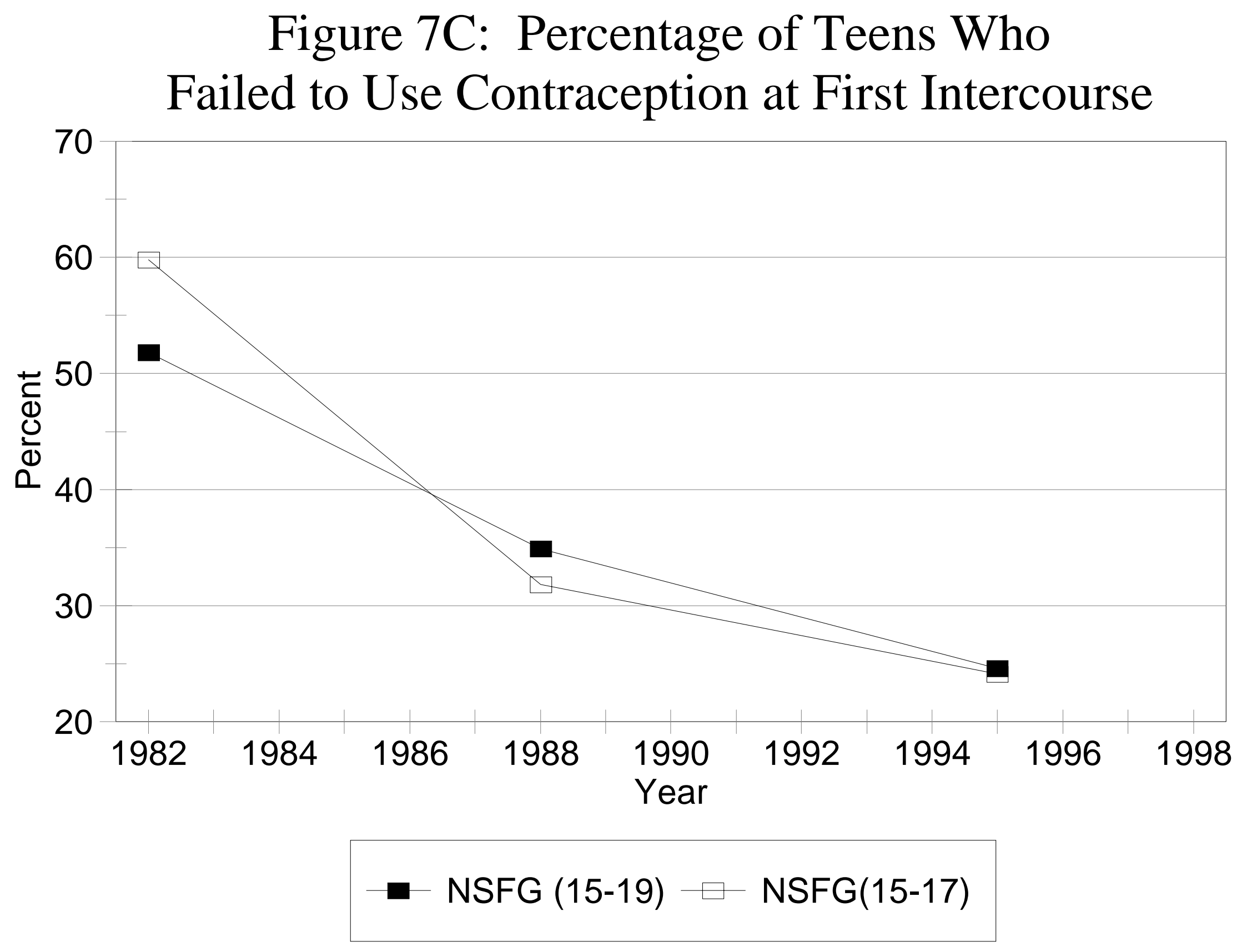

Source: Author's calculations from the NSFG. 


\section{Figure 8: Percentage of Teens that are "At-Risk of Pregnancy"}

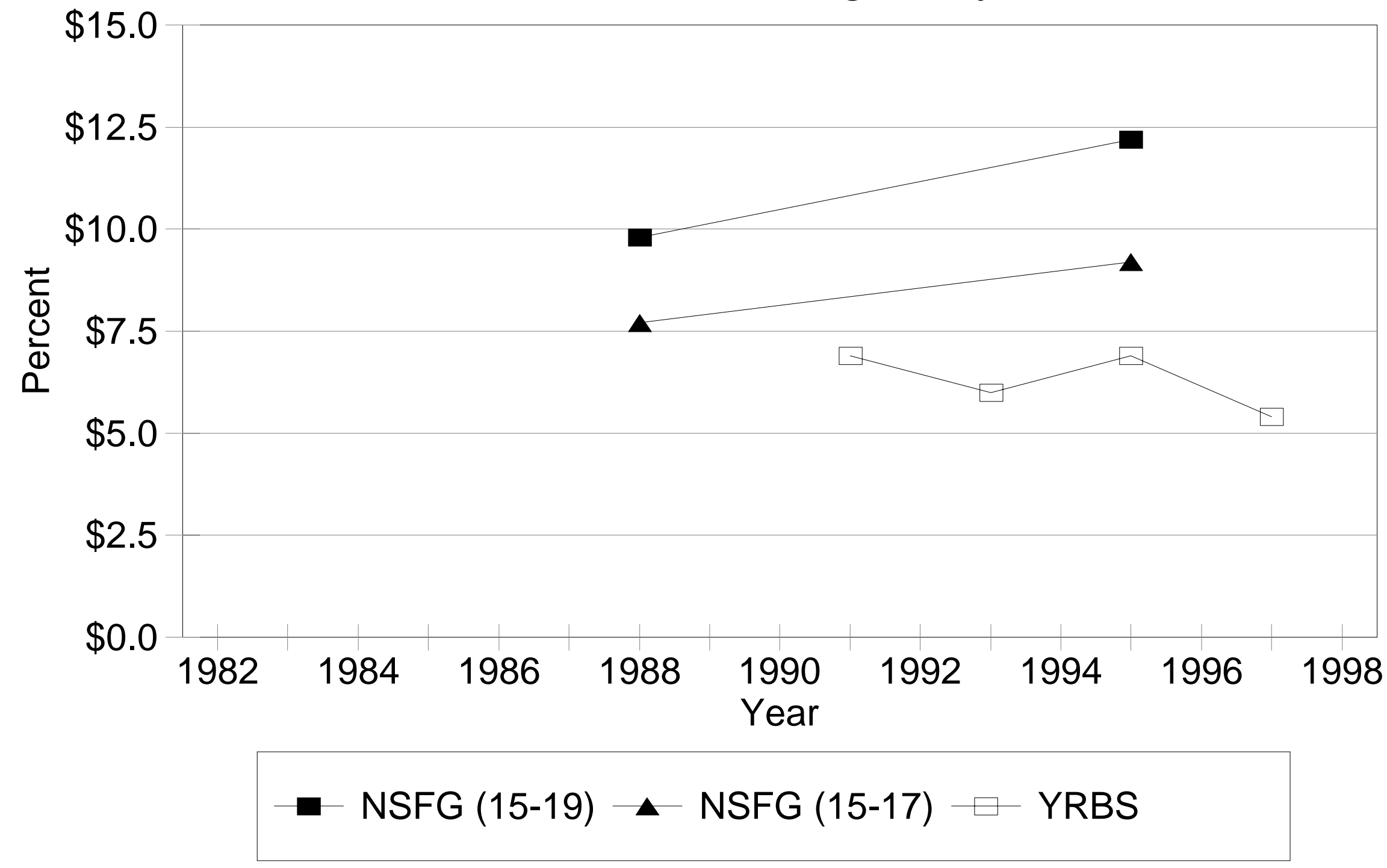

Source: Author's calculations from the NSFG and YRBS. 


\section{Figure 9: Teen Sexuality Decision Tree}

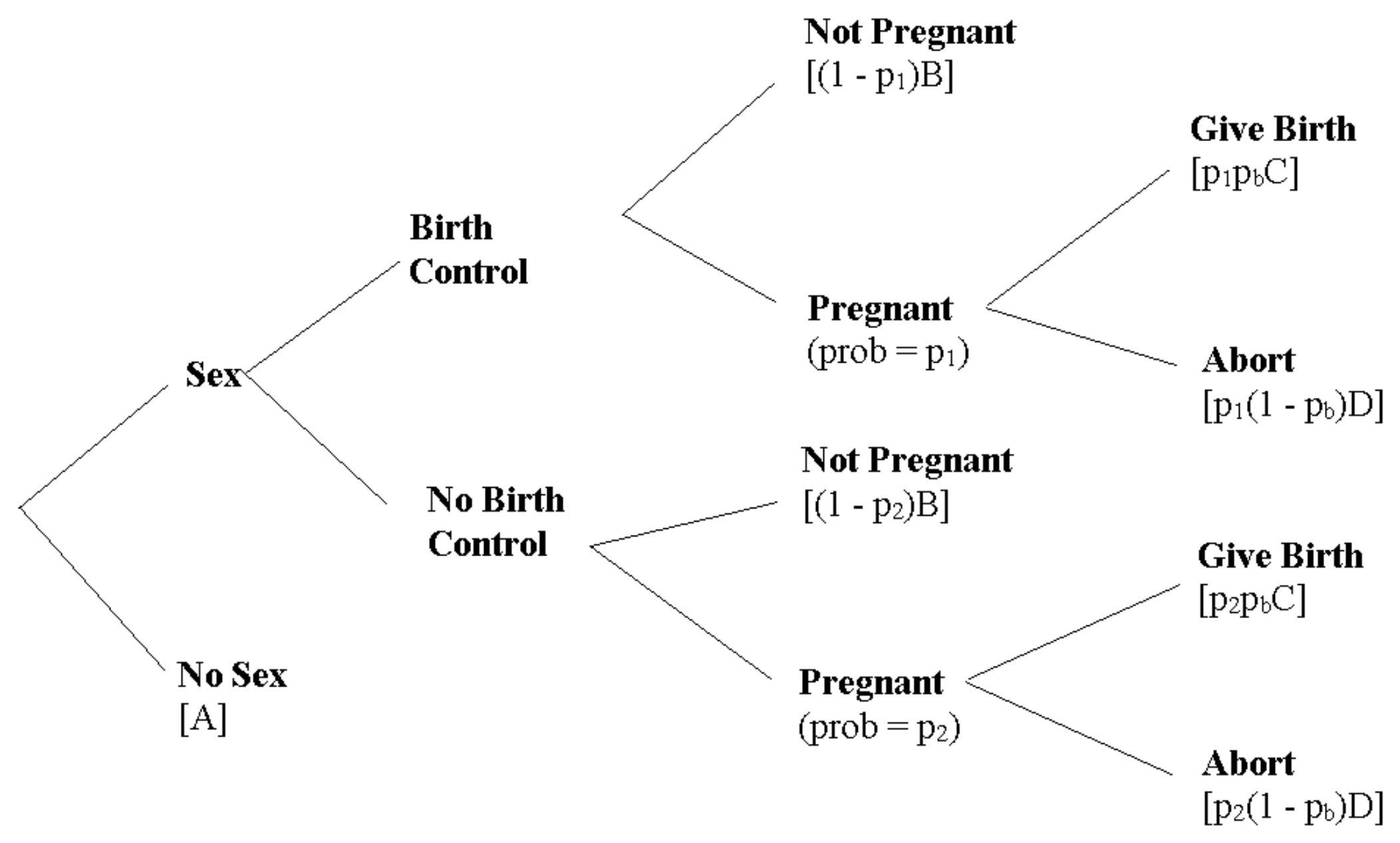

